\title{
EFEITO DO TRATAMENTO COM CALOR E BAIXA UMIDADE SOBRE CARACTERÍSTICAS FÍSICAS E FUNCIONAIS DOS AMIDOS DE MANDIOQUINHA-SALSA (Arracacia xanthorrhiza), DE BATATA- DOCE (Ipomoea batatas) E DE GENGIBRE (Zingiber officinale)
}

\author{
FABIANA DO CARMO VIEIRA
}

\footnotetext{
Dissertação apresentada à Escola Superior de Agricultura "Luiz de Queiroz", Universidade de São Paulo, para obtenção do título de Mestre em Ciências, Área de Concentração: Ciência e Tecnologia de Alimentos.
}

\author{
PIR A C I C A B A \\ Estado de São Paulo - Brasil \\ Julho - 2004
}




\title{
EFEITO DO TRATAMENTO COM CALOR E BAIXA UMIDADE SOBRE CARACTERÍSTICAS FÍSICAS E FUNCIONAIS DOS AMIDOS DE MANDIOQUINHA-SALSA (Arracacia xanthorrhiza), DE BATATA- DOCE (Ipomoea batatas) E DE GENGIBRE (Zingiber officinale)
}

\section{FABIANA DO CARMO VIEIRA}

Engenheira Química

Orientador: Profa . Dra. SILENE BRUDER SILVEIRA SARMENTO

\begin{abstract}
Dissertação apresentada à Escola Superior de Agricultura "Luiz de Queiroz", Universidade de São Paulo, para obtenção do título de Mestre em Ciências, Área de Concentração: Ciência e Tecnologia de Alimentos.
\end{abstract}

PIRACICABA

Estado de São Paulo - Brasil

Julho - 2004 


\section{Dados Internacionais de Catalogação na Publicação (CIP) DIVISÃO DE BIBLIOTECA E DOCUMENTAÇÃO - ESALQ/USP}

\section{Vieira, Fabiana do Carmo}

Efeito do tratamento com calor e baixa umidade sobre características físicas e

funcionais dos amidos de mandioquinha-salsa (Arracacia xanthorrhiza), de batata-doce

(Ipomoea batatas) e de gengibre (Zingiber officinale) / Fabiana do Carmo Vieira - -

Piracicaba, 2004

103 p. : il.

Dissertação (mestrado) - - Escola Superior de Agricultura Luiz de Queiroz, 2004.

Bibliografia.

1. Amido - Propriedades físicas 2. Batata-doce 3. Calor 4. Gengibre 5. Mandioquinhasalsa 6. Umidade I. Título

CDD 664.2 
Dedico esse trabalho à minha família, em especial à minha mãe que sempre acreditou em mim e me apoiou.

Ao meu amado marido Jackson pelo amor, pelo carinho, por me ouvir, compreender e apoiar todos esses anos. 


\section{AGRADECIMENTOS}

Em primeiro lugar à Deus, por ter me dado mais essa oportunidade de crescimento, por me sustentar nos momentos difíceis e me mostrar as dádivas que sempre me reserva.

À minha mãe Glória pelo apóio e amor incondicionais.

Ao meu marido Jackson pelo amor, pelo companheirismo e pelos sacrifícios que teve que fazer para que eu pudesse estudar.

Ao meu irmão Fabrício pela ajuda no preparo das amostras de amido e pela amizade e ao meu irmão Fágner e a minha cunhada Janaína pela companhia e paciência nas viagens para Piracicaba.

Ao meu pai José pelo apoio e pela amizade e por me ensinar a ter paciência.

Á Profa ${ }^{a}$ Dra ${ }^{a}$ Silene Bruder Silveira Sarmento pela orientação nesse curso e pela amizade.

À Carlota Borrali dos Anjos pela amizade, pela paciência e pela realização das análises laboratoriais .

Aos estagiários Cléber, Manoel e Elisa pela amizade e pela grande ajuda na realização das análises.

Áo Profo ${ }^{\circ}$ Dro. Quirino e a Técnica de laboratório Nirvana pelas análises de fósforo.

Ao NUPEGEL/ESALQ e ao Técnico Sérgio Luís de Jesus pelas análises de raios-X.

Ao Prof $^{\circ}$ Elliot Kitajima pelas análises de MEV.

À Profa Dra. Solange Brazaca e `a Técnica Lurdes do LAN pela digestão do amido para a análise de fósforo.

À Técnica Cleomar de Carvalho do LAN pela ajuda na análise de proteínas. 
Ao Prof $^{\circ}$.Dro ${ }^{\circ}$ André Ricardo Alcarde e ao Prof ${ }^{\circ}$.Dr ${ }^{\circ}$. Jorgi Horii do LAN pelo empréstimo da incubadora e pelos conselhos.

À Prof ${ }^{a}$. Dr ${ }^{a}$. Marney Pascoli Cereda, ao Prof ${ }^{\circ}$. Pr $^{\circ}$. Severino Matias de Alencar e `a Técnica Maria Antônia Calori pelas sugestões oferecidas.

'A Profa Dra. Marília Oetterer pelo empréstimo dos equipamentos para realização das análises.

À ESALQ/ USP/ LAN pela disponibilização das instalações para a realização deste trabalho.

À CAPES pela concessão da bolsa de estudos.

Aos meus colegas da Ford, em especial Lucilaine, Frias, Manduca, Davi, Tadeu , Mauro e Wágner pelo apoio e companheirismo.

'A Ford motor Company pela dispensa parcial do trabalho para que eu pudesse terminar o mestrado.

'As minhas queridas amigas Daniela, Eliciara, Andréa e Karina pelo apoio, amizade nas horas mais difíceis.

'A minha Sogra Junyse Aparecida pela amizade, apoio e paciência que teve comigo.

Aos meus queridos amigos da pós-graduação, Cristiane, Márcia, Vanessa, Camila, Christiann e Nilo, pela ajuda nessa caminhada.

Aos meus colegas do Centro de Estudos Espirituais/SP e do Centro Espírita de Tatuí pelo apoio, amizade e companheirismo. 


\section{SUMÁRIO}

Página

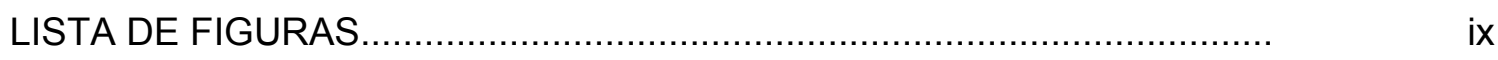

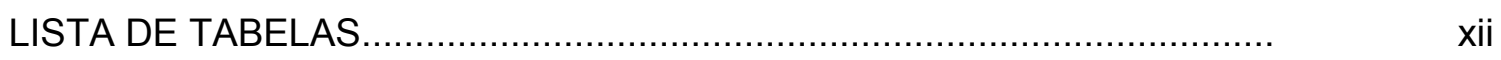

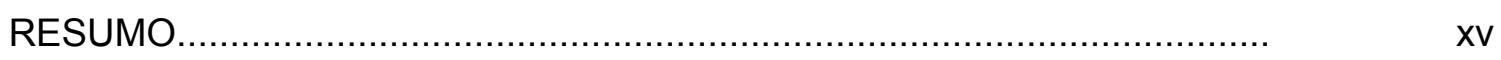

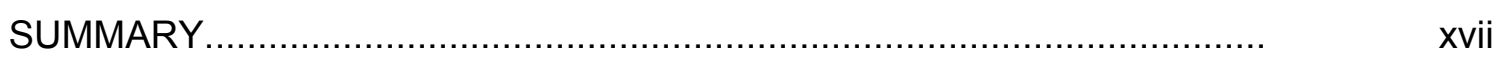

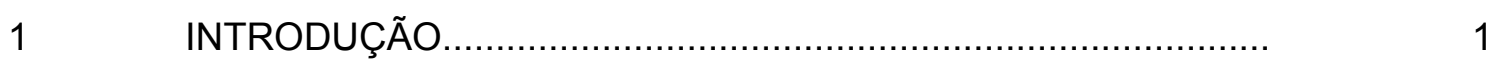

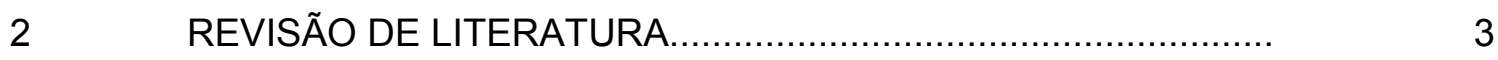

$2.1 \quad$ Descrição das tuberosas amiláceas......................................... 3

$2.2 \quad$ Composição do amido.......................................................

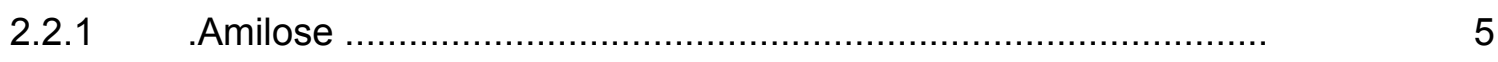

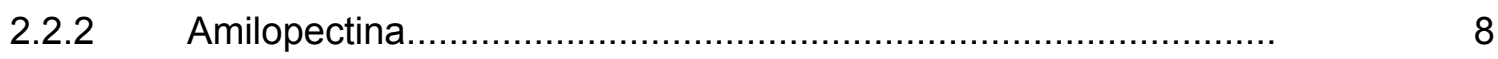

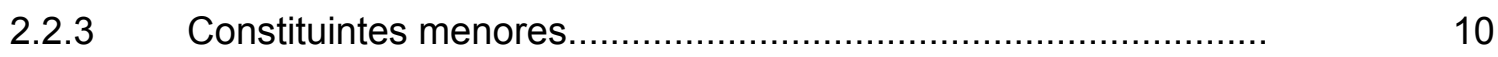

2.3 A estrutura dos grânulos de amido.................................... 11

2.3.1 Forma e tamanho..............................................................

2.3.2 Estrutura granular....................................................... 12

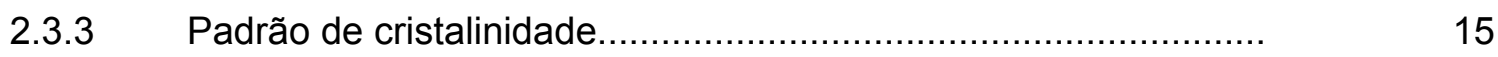

2.4 A gelatinização do amido................................................. 20

2.5 Ação de enzimas sobre o amido............................................ 20

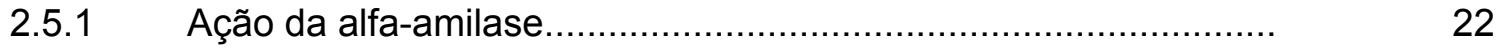

2.5.2 Ação da amiloglucosidase .................................................... 23

2.5.3 Ação conjunta da alfa-amilase e amiloglucosidase...................... 24

2.3.6 Tratamento térmico do amido em baixos teores de umidade................................................................... 25

3 MATERIAL E MÉTODOS............................................. 28

$3.1 \quad$ Material................................................................... 28 


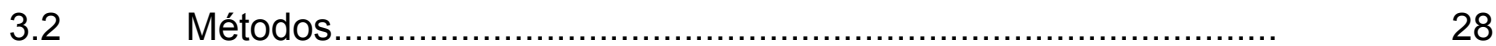

3.2.1 Extração do amido das tuberosas amiláceas................................. 28

3.2.1.1 Extração do amido de mandioquinha-salsa................................. 30

3.2.1.2 Extração do amido de batata-doce............................................

3.2.1.3 Extração do amido de gengibre..................................................

3.2.2 Composição dos amidos extraídos.............................................. 33

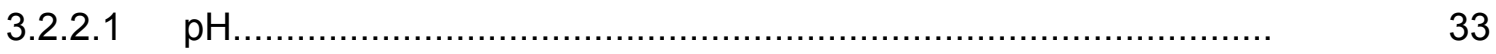

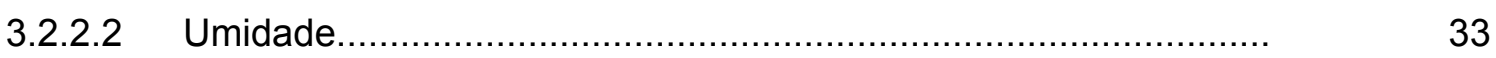

3.2.2.3 Lipídeos .......................................................................

3.2.2.4 Cinza

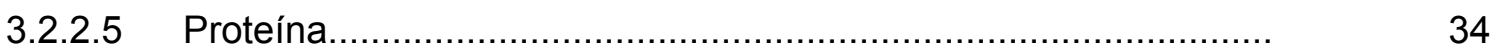

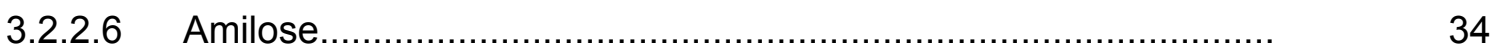

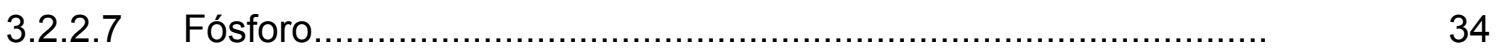

3.2.3 Formato e tamanho dos grânulos de amido................................ 34

3.2.4 Tratamento do amido com calor em baixa umidade...................... 35

3.2.5 Digestão enzimática dos grânulos de amido................................. 35

3.2.5.1 Atividade da alfa-amilase bacteriana........................................... 36

3.2.5.2 Atividade da amiloglucosidase fúngica........................................ 37

3.2.5.3 Digestão enzimática dos grânulos de amido............................... 37

3.2.6 Características dos grânulos e pastas de amidos tratados e não tratados pela alfa-amilase e amiloglucosidase ............................... 38

3.2.6.1 Microscopia eletrônica de varredura …………………….......... 38

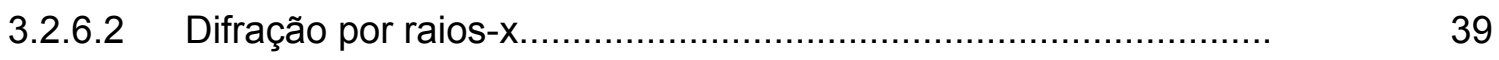

3.2.6.2 Propriedades de pasta dos amidos............................................ 39

3.2.7 Tratamento estatístico............................................................

$4 \quad$ RESULTADOS E DISCUSSÃO..............................................

4.1 Características dos grânulos de amidos .......................................

4.2 Composição dos grânulos de amidos.........................................

4.3 Digestibilidade enzimática dos amidos naturais e tratados termicamente sob baixa umidade............................................. 52

4.3.1 Percentual de hidrólise dos amidos....................................... 52

4.3.2 Cinética da digestibilidade enzimática dos amidos....................... 54 
4.4 Aspectos dos grânulos de amido vistos ao microscópio eletrônico de varredura............................................

$4.5 \quad$ Difração de raio-x.................................................

4.6 Propriedades de pasta dos amidos ............................. 81

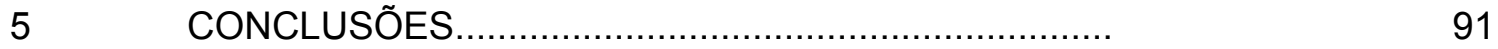

REFERÊNCIAS BIBILIOGRÁFICAS....................... 94 


\section{LISTA DE FIGURAS}

Página

1 Ligações $\alpha-1,4$ da molécula de amilose................................................. 5

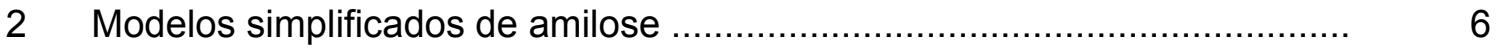

3 Modelo molecular representando o complexo amilose - ácido graxo, mostrando a inclusão da parte alifática do ácido graxo dentro da cavidade hidrofóbica

4 Ligações $\alpha-(1-4)$ e $\alpha-(1-6)$ na amilopectina sendo 1-regiões cristalinas, 2regiões amorfas, $\varnothing$ - extremidade redutora........................................... 9

5 Estrutura proposta para amilopectina, com cadeias A, B e C....................... 10

6 Modelo de um cristal de amido demonstrando os arranjos entre a amilose, a amilopectina e os ácidos graxos

7 Diferentes níveis de organização dos grãos de amido: a) esquema do grão inteiro; b) camadas semi-cristalinas constituídas do empilhamento de lamelas amorfas e cristalinas; c) correspondência entre o modelo bioquímico das lamelas cristalinas e amorfas.

8 Esquema do arranjo da molécula de amilopectina no anel de crescimento.

9 Diagrama de difração de raios-x dos amidos de cristalinidade tipo A, B e C......

10 Modelo simplificado para a estrutura de padrão V.

11 Empacotamento cristalino das hélices duplas no tipo $A$ e no tipo $B$ e projeção da estrutura no plano.

12 Ação das enzimas amilolíticas. A: $\alpha$-amilase; G: amiloglucosidase; $ø$ : 
extremidade

redutora.

13 Ação da alfa-amilase em moléculas de amido............................................ 22

14 Ação da amiloglucosidase em oligossacarídeos ramificados........................ 24

15 Aspecto das tuberosas utilizadas para extração do amido. (A) mandioquinha-salsa, $(B)$ batata-doce, $(C)$ gengibre.

16 Fluxograma do processo de extração do amido de mandioquinhasalsa.

17 Fluxograma do processo de obtenção do amido de batata-doce.

18 Fluxograma do processo de obtenção do amido de gengibre.

19 Quadro dos parâmetros do Rapid Visco Analyser utilizados para determinação das propriedades das pastas dos amidos.

20 Curva típica do RVA...

21 Imagem dos amidos mandioquinha-salsa (a), batata-doce (b) e de gengibre (c) em microscópio óptico.

22 Histogramas dos diâmetros mínimo e máximo dos amidos da mandioquinha-salsa (A e B), da batata-doce (C e D) e do gengibre (E e $\mathrm{F})$.

23 Teores de açúcares redutores produzidos durante a digestão enzimática dos amidos de mandioquinha-salsa, batata-doce e gengibre, tanto no estado natural (granular) como após tratamento com calor e baixa umidade (TCBU).

24 Fotos dos amidos de mandioquinha-salsa em microscópio eletrônico de varredura $(20 \mathrm{kV} / 12 \mathrm{~mm})$

25 Fotos dos amidos de mandioquinha-salsa após digestão enzimática em microscópio eletrônico de varredura $(20 \mathrm{kV} / 12 \mathrm{~mm})$

26 Fotos dos amidos de mandioquinha-salsa tratados termicamente sob baixa umidade em microscópio eletrônico de varredura $(15 \mathrm{kV} / 12 \mathrm{~mm})$.

27 Foto dos amidos de mandioquinha-salsa tratados termicamente sob baixa 
umidade, após digestão enzimática, em microscópio eletrônico de varredura $(15 \mathrm{kV} / 12 \mathrm{~mm})$

28 Fotos dos amidos de batata-doce em microscópio eletrônico de varredura $(10 \mathrm{kV} / 12 \mathrm{~mm})$

29 Fotos dos amidos de batata-doce após digestão enzimática, em microscópio eletrônico de varredura $(15 \mathrm{kV} / 17 \mathrm{~mm})$

30 Fotos dos amidos de batata-doce tratados termicamente sob baixa umidade, em microscópio eletrônico de varredura (20kV/12mm).

31 Fotos dos amidos de batata-doce tratados termicamente sob baixa umidade, após digestão enzimática, em microscópio eletrônico de varredura $(15 \mathrm{kV} / 12 \mathrm{~mm})$

32 Fotos dos amidos de gengibre em microscópio eletrônico de varredura $(15 \mathrm{kV} / 12 \mathrm{~mm})$

33 Fotos dos amidos de gengibre após digestão enzimática, em microscópio eletrônico de varredura

34 Fotos dos amidos de gengibre tratados termicamente sob baixa umidade, em microscópio eletrônico de varredura (15kV/12mm)

35 Fotos dos amidos de gengibre tratados termicamente sob baixa umidade, após digestão enzimática, em microscópio eletrônico de varredura $(15 \mathrm{kV} / 12 \mathrm{~mm})$.

36 Perfis de difração de raios- $x$ dos amidos de mandioquinha-salsa natural (NAT), natural submetido a digestão enzimática (NAT DIG), submetido a tratamento térmico em baixa umidade (TCBU) e submetido a tratamento térmico em baixa umidade e digestão enzimática (TCBU DIG).

37 Perfis de difração de raios-x dos amidos de batata-doce natural (NAT), natural submetido a digestão enzimática (NAT DIG), submetido a tratamento térmico em baixa umidade (TCBU) e submetido a tratamento térmico em baixa umidade e digestão enzimática (TCBU DIG).

38 Perfis de difração de raios-x dos amidos de gengibre natural (NAT), 
natural submetido a digestão enzimática (NAT DIG), submetido a tratamento térmico em baixa umidade (TCBU) e submetido a tratamento térmico em baixa umidade e digestão enzimática (TCBU DIG).

39 Perfis viscoamilográficos do amido extraído de mandioquinha-salsa (natural) e após sua digestão enzimática (natural digerido), tratado termicamente em baixa umidade (TCBU), e tratado termicamente em baixa umidade após a digestão enzimática (TCBU digerido)

40 Perfis viscoamilográficos do amido de batata-doce (natural) e após sua digestão enzimática (natural digerido), tratado termicamente em baixa umidade (TCBU), e tratado termicamente em baixa umidade após a digestão enzimática (TCBU digerido)

41 Perfis viscoamilográficos do amido de gengibre (natural) e após sua digestão enzimática (natural digerido), tratado termicamente em baixa umidade (TCBU), e tratado termicamente em baixa umidade após a digestão enzimática (TCBU) 


\section{LISTA DE TABELAS}

Página

1 Tamanho médio dos grânulos de amido extraído das tuberosas.......... 44

2 Teores de cinzas (\% base seca) dos amidos das tuberosas ............... 47

3 Teores de proteína bruta dos amidos das tuberosas.......................... 48

4 Teores de lipídeos (\% base seca) nos amidos das tuberosas amiláceas............................................................................... 49

$5 \quad$ Teores de fósforo nos amidos das tuberosas............................... 50

6 Teores de amilose aparente nos amidos das tuberosas....................... 51

7 Porcentagem de hidrólise dos amidos das tuberosas, naturais e tratados com calor sob baixa umidade, após 24 horas de digestão enzimática.

8 Intensidades dos principais picos dos difratogramas de raios- $x$ dos amidos de mandioquinha-salsa, tratados e não tratados com TCBU, antes e após a digestão enzimática.

9 Intensidades dos principais picos dos difratogramas de raios- $x$ dos amidos de batata-doce, tratados e não tratados com TCBU, antes e após a digestão enzimática.

10 Intensidades dos principais picos dos difratogramas de raios-X dos amidos de gengibre, tratados e não tratados com TCBU, antes e após a digestão enzimática.

11 Padrões de difração de raios $\mathrm{x}$ dos amidos de mandioquinha salsa, batata doce e gengibre, sob a forma natural, após tratamento com calor em baixa umidade e após digestão enzimática.

12 Propriedades de pasta de suspensões $(2,5 \mathrm{~g} / 25 \mathrm{~mL}$ água) de amido extraído de mandioquinha salsa (natural) e após digestão enzimática 
(natural digerido), após tratamento com calor em baixa umidade (TCBU) e após tratamento com calor em baixa umidade e digestão enzimática (TCBU digerido).

13 Propriedades de pasta de suspensões (2,5g/25mL água) de amido extraído de batata doce (natural) e após a digestão enzimática (natural digerido), após tratamento com calor em baixa umidade (TCBU), e após tratamento com calor em baixa umidade e digestão enzimática (TCBU digerido)

14 Propriedades de pasta de suspensões $(2,5 \mathrm{~g} / 25 \mathrm{~mL}$ água) de amido extraído de gengibre (natural) e após a digestão enzimática (natural digerido), após tratamento com calor em baixa umidade (TCBU), e após tratamento com calor em baixa umidade e digestão enzimática (TCBU digerido) 


\title{
EFEITO DO TRATAMENTO COM CALOR E BAIXA UMIDADE SOBRE CARACTERÍSTICAS FÍSICAS E FUNCIONAIS DOS AMIDOS DE MANDIOQUINHA- SALSA (Arracacia xanthorrhiza), BATATA-DOCE (Ipomoea batatas) E GENGIBRE (Zingiber officinale)
}

\author{
Autora: FABIANA DO CARMO VIEIRA \\ Orientador: Profa. Dra ${ }^{a}$. SILENE BRUDER SILVEIRA SARMENTO
}

\section{RESUMO}

O objetivo do presente trabalho foi o de obter maiores informações acerca das modificações causadas pelo tratamento com calor e baixa umidade (TCBU) sobre a estrutura granular e propriedades funcionais dos amidos extraídos de mandioquinhasalsa, gengibre e batata-doce, fontes alternativas desse carboidrato. Os amidos foram extraídos desses vegetais e caracterizados quanto à composição macromolecular, substâncias acompanhantes, tamanho e forma dos grânulos. Para avaliar o efeito do tratamento térmico e baixa umidade $\left(100^{\circ} \mathrm{C}, 27 \%\right.$ de umidade, 16 horas), os amidos foram submetidos a processo de digestão enzimática pela alfa-amilase de Bacillus $s p$ e amiloglucosidase de Rhizopus mold. As amostras obtidas foram avaliadas quanto ao modo de ataque das enzimas aos grânulos em microscópio eletrônico de varredura (MEV), padrão de cristalinidade por difração de raios-x e propriedades da pasta em Rapid Visco Analyser (RVA). O amido de mandioquinha-salsa apresentou $17 \%$ de amilose e $0,032 \%$ de fósforo, tamanho médio de grânulo de $12,5 \times 17,3 \mu \mathrm{m}$, padrão $B$ de cristalinidade e $38 \%$ de hidrólise enzimática. $O$ amido de batata-doce apresentou $22 \%$ de amilose, $0,027 \%$ de fósforo, tamanho médio de grânulo de $20,4 \times 26,2 \mu \mathrm{m}$, 
padrão A de cristalinidade e $72 \%$ de hidrólise. O amido de gengibre apresentou $25 \%$ de amilose, 0,022\% de fósforo, tamanho médio de grânulos de 17,6 x 23,2 $\mu \mathrm{m}$, padrão A de cristalinidade e $15 \%$ de hidrólise. O tratamento com calor e baixa umidade nas condições do estudo provocou aumento na suscetibilidade à ação enzimática em todos os amidos, mas principalmente no de mandioquinha-salsa. Com este tratamento ocorreram também alterações na intensidade dos picos nos difratogramas de raios- $x$, entretanto, os padrões de cristalinidade dos amidos não foram alterados. Os perfis e valores dos viscoamilogramas dos amidos estudados foram substancialmente alterados com o tratamento térmico em baixa umidade, havendo elevação da temperatura de pasta e do tempo para ocorrência do pico, redução nos valores de viscosidade e extinção da quebra, ou seja, estabilização da viscosidade dos amidos quando sob temperaturas elevadas e agitação mecânica. O tratamento térmico sob baixa umidade, nas condições do estudo, promoveu alterações que apontam para um rompimento seguido de rearranjo das associações internas na estrutura granular do amido fazendo com que ocorra redução da cristalinidade e aumento significativo de sua área acessível à ação enzimática. 


\title{
EFFECT OF HEAT-MOISTURE TREATMENT IN PHYSICS AND FUNCIONALS CARACTERISTICS OF PERUVIAN CARROT STARCH (Arracacia xanthorrhiza), OF SWEET POTATO STARCH (Ipomoea batatas) AND OF GINGER STARCH (Zingiber officinale)
}

\author{
Author: FABIANA DO CARMO VIEIRA \\ Adviser: Profa. Dra. SILENE BRUDER SILVEIRA SARMENTO
}

\section{ABSTRACT}

The goal of this work is to obtain more information about the modifications caused by heat-moisture treatment (TCBU) on the granular structure and functional properties extracted of starch Peruvian carrot, sweet potato and ginger, sources alternative sources of this carbohydrato. The starches were extracted of these vegetables and how characterized macromolecular composition, non-starch components, size and form of granules. To evaluate effect of heat-moisture treatment (HMT- $100^{\circ} \mathrm{C}, 27 \%$ of humidity, 16 hours), starches had been submittedby to enzymatic digestion with alpha-amilase of Bacillus $\mathrm{sp}$ and amiloglucosidase of Rhizopus mold. The samples had been evaluated about the way of enzymes attack to granules in scanning electron microscope (SEM), pattern of cristallinity for rays- $X$ diffraction and properties of the paste in Rapid Visco Analyser (RVA). The peruvian carrot starch presented amylose content of $17 \%$ and phosphorus content of $0,032 \%$, granule average size of $12,5 \times 17,3 \mu \mathrm{m}$, standard B of cristallinity and $38 \%$ of enzymatic hydrolysis. The sweet potato starch presented of amylose content of $22 \%$, phosphorus 
content of $0,027 \%$, granule average size of $20,4 \times 26,2 \mu \mathrm{m}$, standard A of cristallinity and $72 \%$ of hydrolysis. The ginger starch presented amylose content of $25 \%$, phosphorus content of $0,022 \%$, granule average sizes of $17,6 \times 23,2 \mu \mathrm{m}$, standard $A$ of cristallinity and $15 \%$ of hydrolysis. Heat-moisture treatment (HMT), in this work, caused increase in susceptibility to enzymatic action in all studied starches, but mainly in peruvian carrot starch. With this treatment had also occurred alterations in rays-x diffraction peaks intensity, however, starches patterns of cristallinity had not been modified. The heat-moisture treatment, in this conditions, changed in the profiles and values of viscosity and increase of susceptibility to enzymatic hydrolysis, what probably, it was caused by the breached crystal rearrangement, starch chain association and disruption of double helices in the amorphous regions. 


\section{INTRODUÇÃO}

O amido é a principal fonte de carboidratos na dieta humana em todo o mundo devido à sua abundância nos vegetais. Formado por polímeros de glucose, o amido é depositado sob a forma de grânulos nas células vegetais podendo ser extraído e utilizado para diversos fins. Pela legislação brasileira (Brasil, 1987) o material amiláceo isolado das partes aéreas dos vegetais é denominado amido e o extraído das partes subterrâneas é chamado fécula. No presente trabalho foi utilizado o termo amido para designar os materiais amiláceos de uma forma geral.

O amido pode ser utilizado em variadas indústrias, sendo as principais consumidoras as alimentícias, as de papel e as têxteis. As necessidades das indústrias que se utilizam deste polissacarídeo estão cada vez mais complexas, fazendo com que o setor produtivo esteja em busca de novas tecnologias, bem como de amidos diferenciados. Estas características funcionais específicas requeridas pelo mercado podem ser maior claridade da pasta, maior estabilidade ao congelamento e descongelamento, resistência a tratamentos estressantes que deterioram a estrutura do gel e outras.

Por apresentar propriedades específicas, variáveis com a fonte botânica, cada amido é considerado único em termos de organização de grânulos e estrutura de seus constituintes macromoleculares. Para incrementar as possibilidades de uso dos amidos extraídos de fontes convencionais, como o milho, o trigo, a batata inglesa e a mandioca, os mesmos podem ser submetidos a processos de modificação química no sentido de moldar os mesmos às necessidades requeridas. Entretanto, o emprego do amido em alguns setores, como o alimentício, é controlado e os motivos dessa restrição são as normas de proteção ao consumidor que se tornaram mais rígidas, a segurança de trabalho e a proteção ao meio ambiente (BeMiller, 1997). Desse modo, houve nos últimos anos uma prospecção intensa de novas matérias primas amiláceas, 
principalmente dentro de tuberosas tropicais latino americanas. A caracterização dos amidos dessas novas fontes, entretanto, ainda não foi completamente explorado.

O tratamento com calor em baixa umidade tem sido apresentado como uma opção de modificação física dos grânulos de amido. O interesse nessa modalidade de modificação tem se ampliado visando a substituição dos amidos modificados quimicamente. Trata-se de processo no qual o amido é submetido a temperaturas superiores ao seu ponto de gelificação, mas com umidade insuficiente para gelificar o mesmo (Thomas \& Atwell, 1999). O tratamento com calor e baixa umidade é uma tendência atual, e por não requerer o uso de reagentes químicos para conferir efeito de modificação, pode ser considerado nativo e rotulado como amido alimentício.

Assim, o objetivo do presente estudo foi o de estudar a influência do tratamento com calor e baixa umidade nas características físicas e funcionais dos amidos extraídos de batata-doce (Ipomoea batatas), mandioquinha-salsa (Arracacia xanthorrhiza) e gengibre (Zingiber officinale). 


\section{REVISÃO DE LITERATURA}

\subsection{Descrição das tuberosas amiláceas}

Segundo Hoover (2001) as culturas tuberosas recebem diversas denominações populares conforme o país em questão. Com relação às propriedades agronômicas já existe grande quantidade de documentação acerca destas culturas, já quanto às propriedades físico-químicas ainda há muito a ser estudado.

A mandioquinha-salsa ou batata-baroa ou cenoura amarela, é uma raiz de uso culinário no Brasil (Camargo Filho et al., 2001). Originária dos Andes, a mandioquinhasalsa é cultivada no Brasil na região Centro-Sul, principalmente em áreas de elevada altitude e clima ameno, como em Minas Gerais, Paraná, Santa Catarina, Espírito Santo e São Paulo, onde ocorrem condições climáticas similares às de seu local de origem (Câmara, 1993). Sua colheita é realizada normalmente aos 11-12 meses do ciclo. No Brasil, a produção de mandioquinha-salsa é quase que exclusivamente destinada ao consumo direto, com exceção de pequena produção de purê desidratado, utilizado na fabricação de sopas instantâneas. (Pereira \& Santos, 1997).

A batata-doce é uma planta de clima tropical ou subtropical, também cultivada em regiões temperadas. É de fácil cultivo, rústica, de ampla adaptação, de alta tolerância à seca e de baixo custo de produção. A batata doce é uma raiz eminentemente calórica sendo o amido seu principal carboidrato. As raízes apresentam em média $70,0 \%$ de umidade, $0,61 \%$ de fibras, $26,0 \%$ de carboidratos, e 1,05\% de cinzas Franco, 2001). Segundo Noda et al. (1992a) a batata-doce possui, em média, 30\% de amido. Noda et al. (1992a) constataram que amidos isolados de diferentes zonas ou tecidos da batata-doce possuem diferentes propriedades físicoquímicas.

No Japão a batata-doce é usada como matéria-prima para produção de amido comercial e amido para fabricar xaropes de glucose e frutose. 
O gengibre é uma planta originária do Sudeste Asiático e somente se tornou uma cultura comercial no Brasil nas últimas décadas. Com relação à cultura, o gengibre exige trabalho intensivo e investimento de capital, requerendo solos adequados, bem drenados e férteis, pois é uma planta esgotante. O principal interesse no cultivo do gengibre no Brasil é a exportação. O principal uso do gengibre é na indústria alimentícia como ingrediente de diversas formulações para molhos, sopas, embutidos e em produtos de padaria e confeitaria (Magalhães et al., 1997).

\subsection{Composição do amido}

BeMiller (1997) afirma que cada amido é único e que quando se reconhece isso abrem-se caminhos para o desenvolvimento de novos produtos. A composição do amido influencia diretamente suas propriedades funcionais. Devido às diferenças estruturais dos diversos tipos de amido não se pode generalizar nada sobre propriedades e comportamentos dos amidos de diferentes fontes botânicas.

Conforme Biliaderis (1991) os grânulos de amido são formados, basicamente, por dois polímeros a amilose e amilopectina. A funcionalidade dos amidos está diretamente relacionada a essas duas macromoléculas e também a organização física das mesmas, dentro da estrutura granular.

A proporção entre amilose e amilopectina varia com a fonte botânica. Além desses dois polímeros principais, em alguns amidos tem sido encontrado um material intermediário, de estrutura muito heterogênea, que consiste de cadeias lineares com grau de polimerização variando de 50 a 200. Este material apresenta algumas ramificações de baixo peso molecular e suas cadeias são mais extensas que as da amilopectina (Biliaderis, 1991). 


\subsubsection{Amilose}

Segundo Thomas \& Atwell (1999) a amilose é um polímero essencialmente linear composto quase que completamente de ligações $\alpha-1,4$ de D-glucopiranose (Figura 1). Recentes evidências, entretanto, sugerem a presença de algumas ramificações nesse polímero. Modelos simplificados para a estrutura de amilose são apresentados na Figura 2. Embora ilustrada tipicamente por uma estrutura linear de cadeia, a amilose de fato é freqüentemente helicoidal. O interior da hélice contém átomos de hidrogênio sendo, portanto, hidrofóbico e permite que a amilose forme complexos com ácidos graxos livres, com componentes glicerídicos dos ácidos graxos, com alguns álcoois e com iodo.

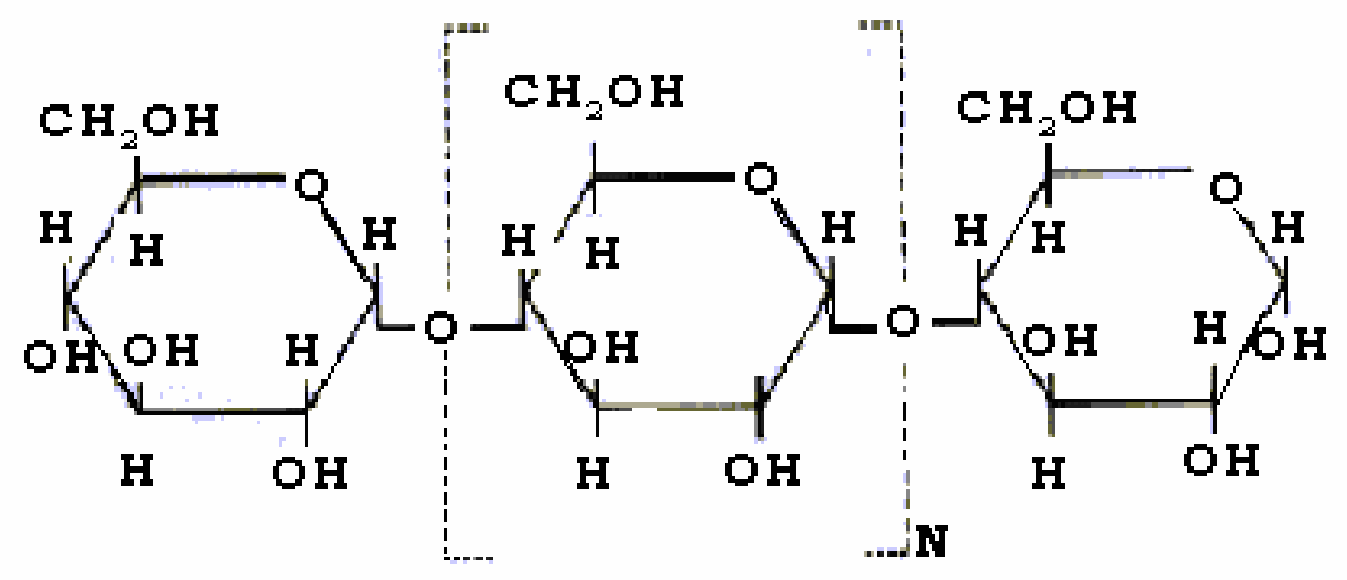

Figura 1 - Ligações $\alpha-1,4$ da molécula de amilose

Fonte: Van Beynum \& Roels (1985) 


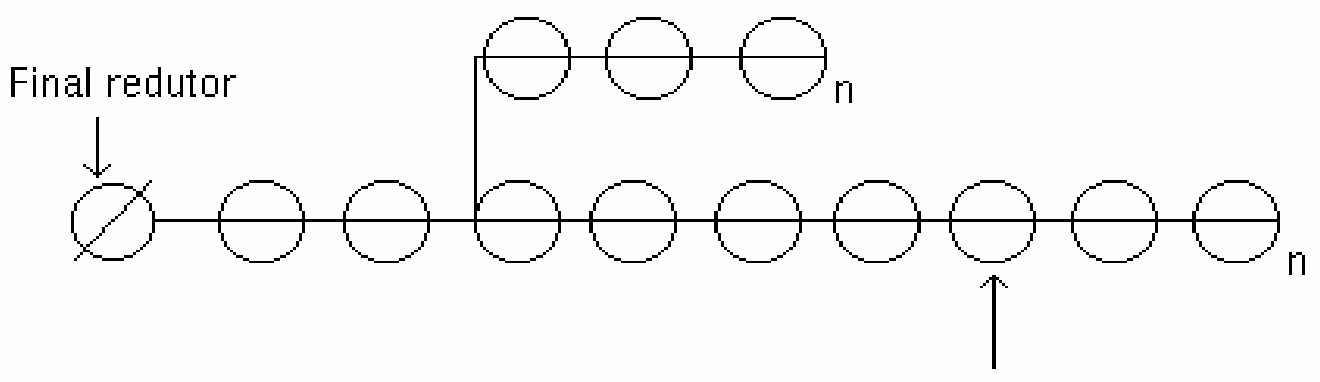

Unidade de D-glucopiranose

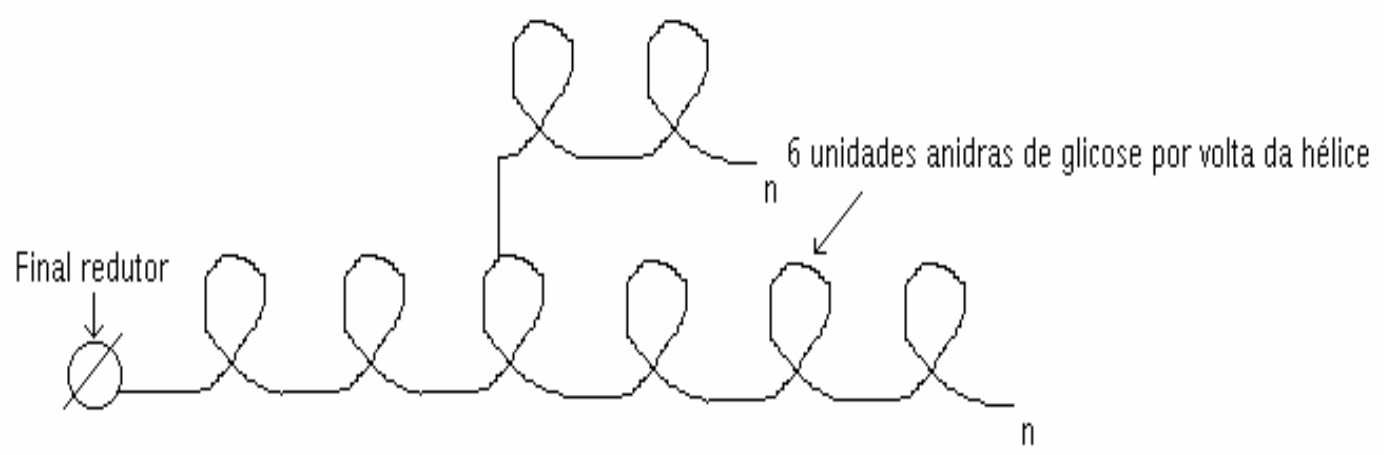

Figura 2 - Modelos simplificados de amilose

Fonte: Thomas \& Atwell (1999)

A complexação com iodo é uma importante ferramenta de diagnóstico para caracterização dos amidos. A complexação com lipídeos, particularmente mono- e diglicerídeos, é uma propriedade bem conhecida da hélice de amilose. A formação e a integridade estrutural dos complexos amilose-lipídeo variam em função de fatores como a temperatura, o $\mathrm{pH}$, o contato e/ou tempo de mistura entre o polímero de amilose (anfitrião) e a molécula visitante, a estrutura do ácido graxo ou glicerídeo. $\mathrm{O}$ resultado do complexo de inclusão (Figura 3), como é freqüentemente chamado, pode alterar as propriedades do amido. Complexos de amilose com gorduras e emulsificantes de alimentos como mono- e di-glicerídeos podem alterar as temperaturas de gelatinização do amido, alterando a textura e o perfil da viscosidade da pasta resultante, e limitando a retrogradação (Thomas \& Atwell,1999). 

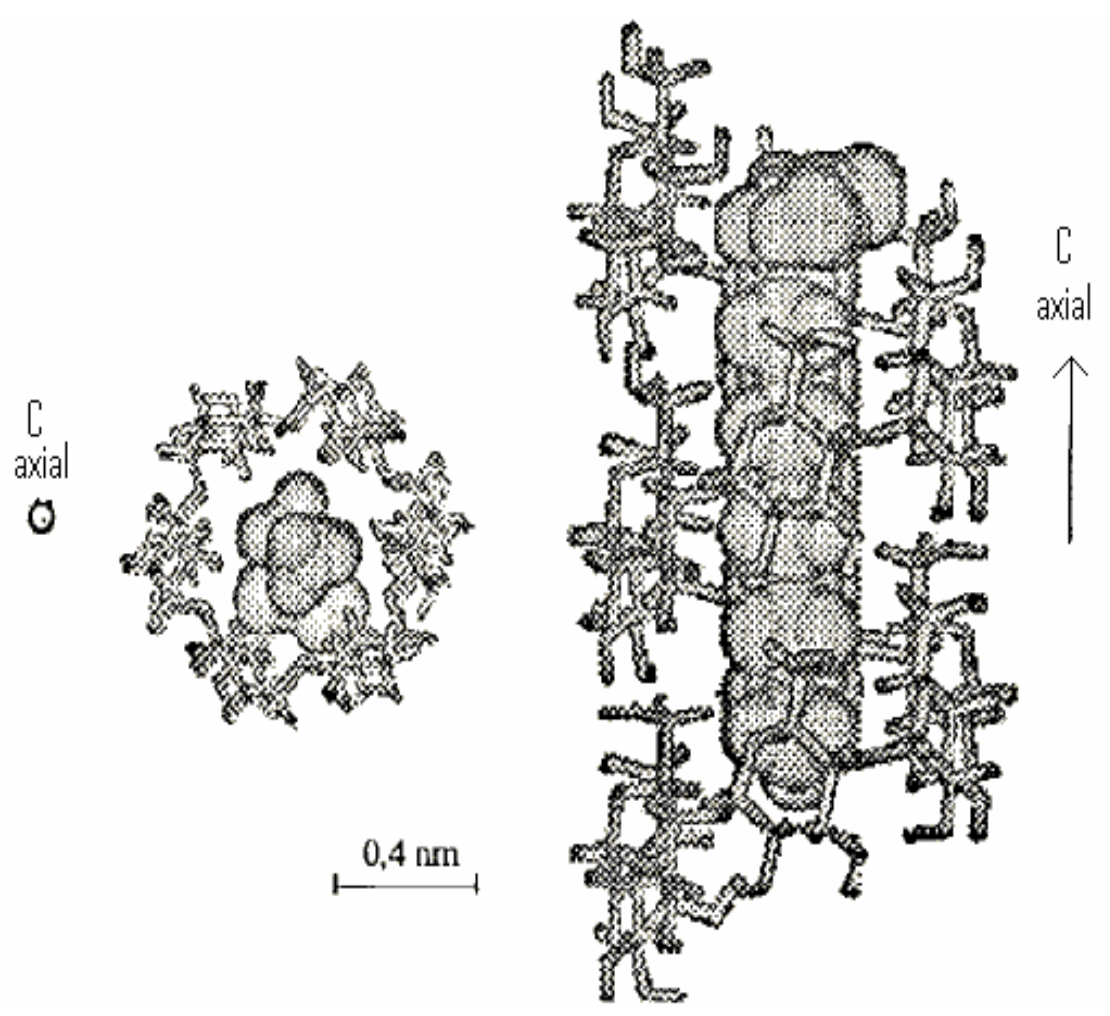

Figura 3 - Modelo molecular representando o complexo amilose - ácido graxo, mostrando a inclusão da parte alifática do ácido graxo dentro da cavidade hidrofóbica da hélice simples de amilose

Fonte: Buléon et al. (1998)

Um outro atributo bem conhecido da amilose é sua habilidade de formar gel depois do grânulo de amido ter sido cozido, isto é, gelatinizado. Este comportamento é evidente em certos amidos que contém maiores teores de amilose. Amido de milho, trigo, arroz e particularmente amido de milho com alto teor de amilose (high-amilose), isolado de plantas híbridas de milho são usualmente considerados amidos gelatinizantes. A formação do gel decorre principalmente da reassociação (chamado de retrogradação) dos polímeros de amido solubilizados depois de cozidos e pode acontecer bem rapidamente com polímeros de cadeia linear (Thomas \& Atwell, 1999).

A amilose apresenta peso molecular característico menor que 0,5 milhão, forma filmes fortes, géis firmes e colore-se de azul com iodo (Thomas \& Atwell, 1999). 
$\mathrm{Na}$ literatura estão disponíveis muitas metodologias para determinar o teor de amilose, entretanto, nenhuma delas é totalmente aceita. Como conseqüência, há grande variação de valores na literatura para uma mesma fonte de amido. O teor de amilose é superestimado porque as ramificações das cadeias de amilopectinas muito longas podem interagir também com o iodo, usado na identificação da amilose, produzindo um resultado mais elevado que o real. $E$ ainda, o teor de amilose reportado nos trabalhos normalmente se refere ao teor de amilose aparente (McPherson \& Jane, 1999). O teor de amilose aparente é usado por muitos autores para se referir à análise efetuada em amido que não foi previamente desengordurado (Morrison, 1995).

Os complexos formados por amilose e lipídeos diminuem a suscetibilidade enzimática da macromolécula de amilose. Isso ocorre devido à existência de um mecanismo competitivo que ocorre entre a formação desses complexos e a retrogradação da amilose. A formação destes complexos também previne a lixiviação das moléculas de amilose durante a gelatinização, inibindo o inchamento do grânulo quando em sistema hidrotérmico (Cui \& Oates, 1999).

\subsubsection{Amilopectina}

Segundo French (1984), a amilopectina é uma macromolécula altamente ramificada formada por unidades de D-glicose ligadas em a-(1-4) e com 5 a $6 \%$ de ligações $\alpha-(1-6)$ nos pontos de ramificação (Figura 4). A grande maioria dos amidos contém $20-30 \%$ de amilose e $70-80 \%$ de amilopectina e essa razão varia com a fonte botânica.

A macromolécula de amilopectina apresenta um grau de polimerização de cerca de $10^{4}-10^{5}$, peso molecular da ordem de $(50-500) \times 10^{6}$ e o comprimento das ramificações é variável, mas é comum apresentarem entre 20 e 30 unidades de glicose (Biliaderis, 1991). Em presença de iodo a amilopectina dá coloração avermelhada e é estável em soluções aquosas diluídas. A amilopectina forma filmes e géis fracos (Thomas \& Atwell, 1999). 


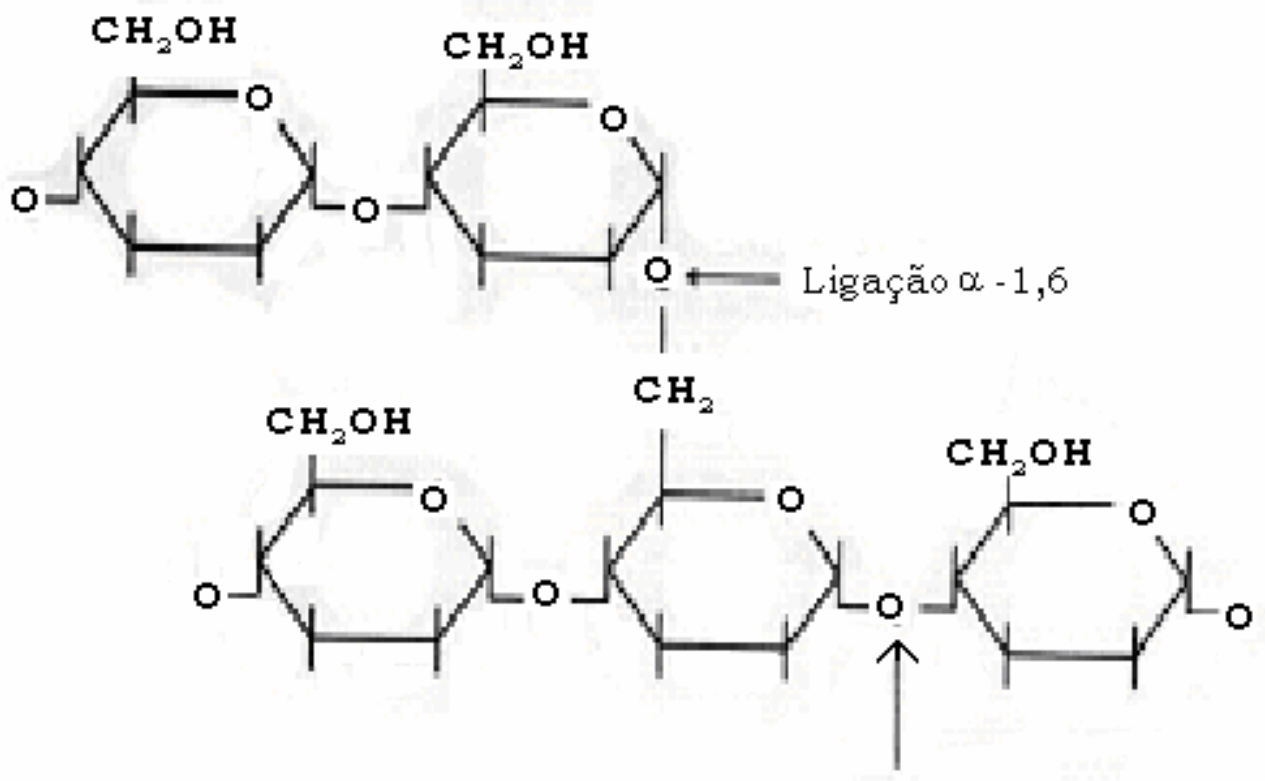

Ligação $\alpha-1,4$

Figura 4 - Ligações $\alpha-(1-4)$ e $\alpha-(1-6)$ na amilopectina

Fonte: Van Beynum \& Roels (1985)

Robin et al. (1974) e French (1973) propuseram que a amilopectina teria formação de clusters ou cachos, onde a molécula de amilopectina consistiria em uma cadeia principal $C$, que carrega o grupo redutor da molécula, e numerosas cadeias ramificadas denominadas $A$ e $B$ (Figura 5 ). As cadeias $A$ são aquelas conectadas a outras cadeias via ligações $\alpha-(1-6)$, mas não carregam qualquer ramificação. Cadeias $B$ são aquelas conectadas a outras cadeias via ligações $\alpha-(1-6)$ e que possuem uma ou mais cadeias $A$ ou $B$ a ela ligadas através de ligações $\alpha-(1-6)$. 


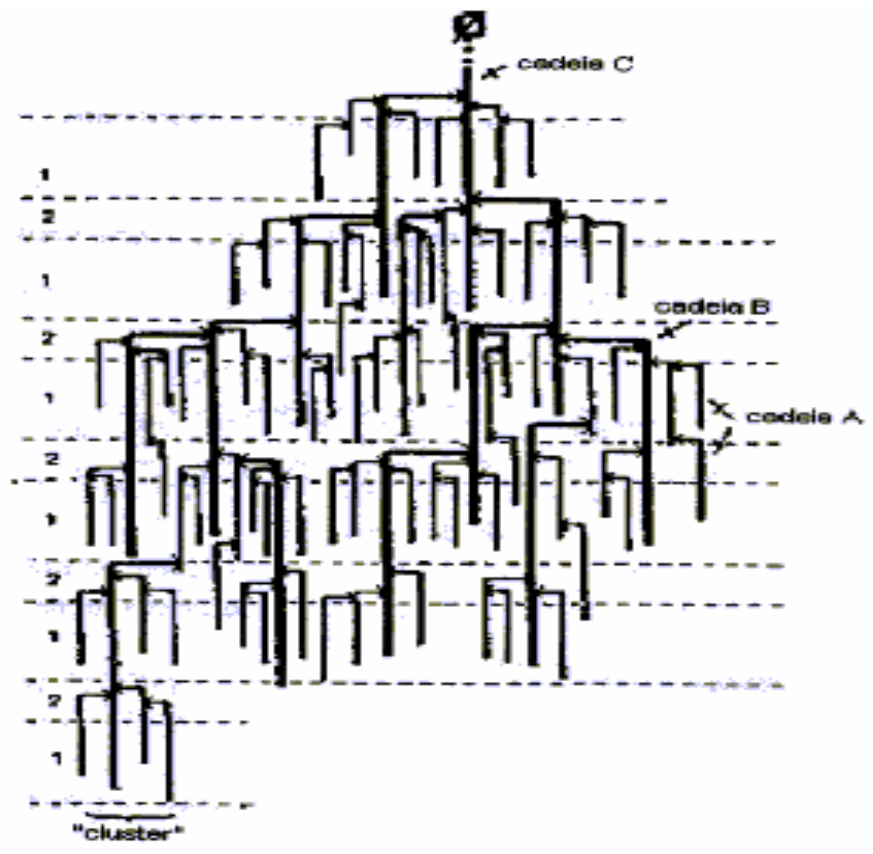

Figura 5 - Estrutura proposta para amilopectina, com cadeias A, B e C sendo 1regiões cristalinas, 2- regiões amorfas, ø- extremidade redutora

Fonte: Robin et al. (1974)

\subsubsection{Constituintes menores}

Os grânulos de amido apresentam outros constituintes além da amilose e da amilopectina. Esses componentes são chamados de constituintes menores e são principalmente os lipídeos, o fósforo, as proteínas e as cinzas (Hoover, 2001).

A fração de lipídeos, quando elevada, pode alterar características como a fixação da cor, o desenvolvimento de aromas e complexações. Entretanto, para os amidos de tuberosas esse fator não é tão importante devido ao baixo percentual deste componente nos mesmos (Buléon et al., 1998). A presença de lipídeos nos grânulos de amido inibe a cristalização das moléculas e afeta as propriedades reológicas das pastas (Wang \& White, 1994).

Segundo Hoover (2001), as proteínas e cinzas aparecem em pequena quantidade em amidos de tubérculos e não chegam a alteram as propriedades funcionais. 
A presença de fósforo em grânulos de amido modifica as propriedades funcionais. Segundo Blennow (2000) o fósforo aparece ligado covalentemente aos grânulos nativos o que altera propriedades como claridade de pastas, aumenta a viscosidade e a consistência.

\subsection{A estrutura dos grânulos de amido}

\subsubsection{Forma e tamanho}

A amilose e a amilopectina não existem livres na natureza, mas como agregados semi-cristalinos organizados em grânulos de amido. O tamanho, a forma e a estrutura desses grânulos variam, substancialmente, entre as fontes botânicas. Os diâmetros dos grânulos geralmente variam de menos de $1 \mu \mathrm{m}$ a mais do que $100 \mu \mathrm{m}$, e os formatos podem ser regulares (por exemplo: esférico, ovóide ou angular) ou bastante irregulares. Os grânulos de trigo, de cevada, e de centeio exibem duas distribuições diferentes de tamanho de grânulos e formas (Thomas \& Atwell, 1999).

O amido de gengibre apresenta grânulos de tamanho médio na faixa de 21,1 a 24,4 $\mu \mathrm{m}$ (Reyes et al., 1982).

Bermudez (1997) $)^{1}$ citado por Franco et al. (2001) encontrou para o grânulo de mandioquinha-salsa as formas elipsóide e truncada e diâmetro médio variando de 8$10 \mu \mathrm{m}$ e para os de batata-doce a forma esférica e diâmetro médio variando de 10$15 \mu \mathrm{m}$. Hoover (2001) encontrou para a batata-doce grânulos de formatos poligonal, oval e redondo, com uma faixa de diâmetro de $2-42 \mu \mathrm{m}$, variável com a variedade e a idade da planta.

1 Bermudez, J.J.H. Valorización de las amilácea "no cereales"cultivadas en los pasíses andinos: estudio de las propriedades fisicoquimicas y funcionales de sus almidones y de la resistência a diferentes tratamientos estressantes. Colômbia, 1997. 150p. Trabajo (Grado) - Faculdad de Ingenieria de Alimentos, Universidad de Bogotá. 


\subsubsection{Estrutura granular}

O grânulo de amido é birrefringente, e sob luz polarizada, apresenta uma típica cruz de Malta, que pode ser cêntrica ou excêntrica. Entretanto, a birrefringência não implica necessariamente em uma forma cristalina e sim num alto grau de organização molecular nos grânulos (Zobel, 1988c). De acordo com Gallant et al. (1997), os grânulos de amido são estruturas semi-cristalinas compostas de macromoléculas arranjadas na direção radial, as macromoléculas formam pontes de hidrogênio por estarem associadas paralelamente o que resulta no aparecimento de regiões cristalinas ou micelas.

Os grânulos de amido são compostos por camadas diversas que se superpõem ao redor de um núcleo chamado hilum, que pode estar no centro do grânulo ou deslocado lateralmente (Van der Burgt et al., 2000). De acordo com Schoch \& Maywald (1956) a posição do hilum é usada como informação para a identificação do material vegetal de origem.

De acordo com Biliaderis (1991), são as áreas cristalinas do amido que mantêm a estrutura de grânulo, controlam o seu comportamento na presença de água e os tornam mais ou menos resistentes aos ataques químicos e enzimáticos. A fase gel ou zona amorfa dos grânulos é a região que é menos densa, mais suscetível aos ataques enzimáticos e absorve mais água em temperaturas abaixo da temperatura de gelatinização. Segundo esse autor não existe uma demarcação forte entre as regiões cristalina e amorfa. Há evidências da existência de uma estrutura supramolecular onde as fases amorfa e cristalina são interdependentes (Figura 6). 


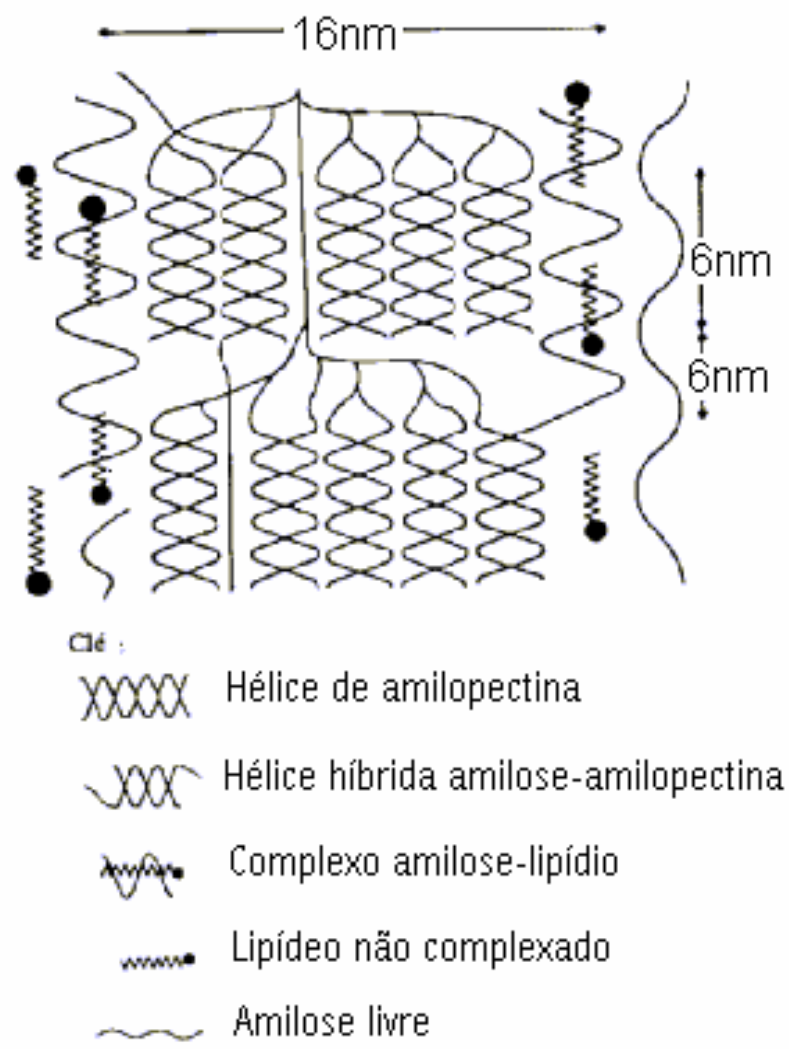

Figura 6 - Modelo de um cristal de amido demonstrando os arranjos entre a amilose, a amilopectina e os ácidos graxos

Fonte: Blanshard (1987)

Imberty et al. (1991) propuseram modelo para a amilopectina, onde essa macromolécula é composta por cadeias curtas e ramificadas que formam organizações locais e isso é compatível ao modelo de cluster (Figura 7) proposto por Robin et al. (1974). 


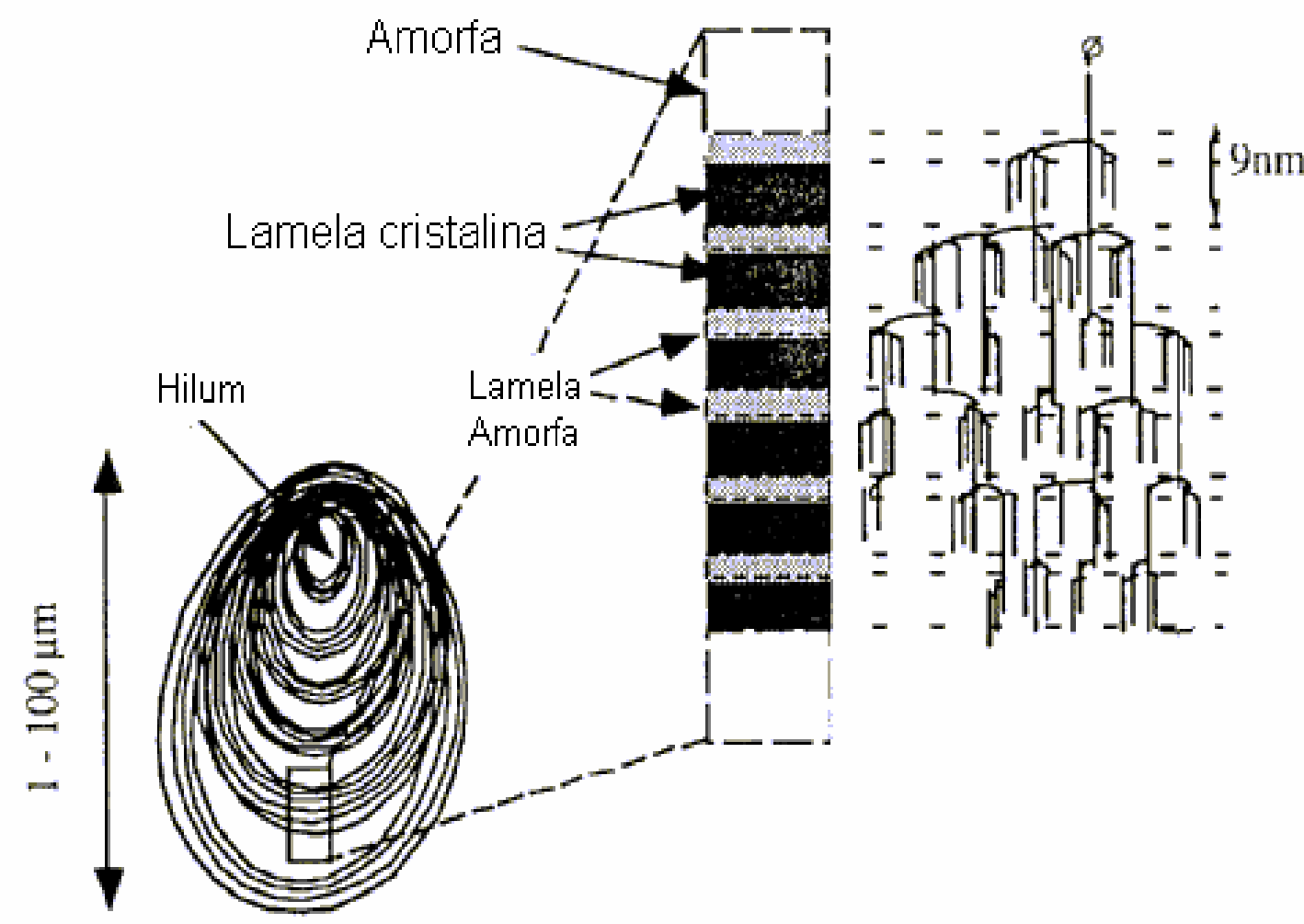

(a)

(b)

(c)

Figura 7 - Diferentes níveis de organização dos grãos de amido: a) esquema do grão inteiro; b) camadas semi-cristalinas constituídas do empilhamento de lamelas amorfas e cristalinas; c) correspondência entre o modelo bioquímico das lamelas cristalinas e amorfas

Fonte: French (1984)

O grânulo de amido, como mostrado pela Figura 8, é formado por zonas alternadas, cristalinas e amorfas, sendo que a parte amorfa corresponde a $20 \AA$ de espessura e a parte cristalina a $50 \AA$. A espessura do anel de crescimento (1200$4000 \AA$ ) equivale ao comprimento da molécula de amilopectina (French, 1984). 


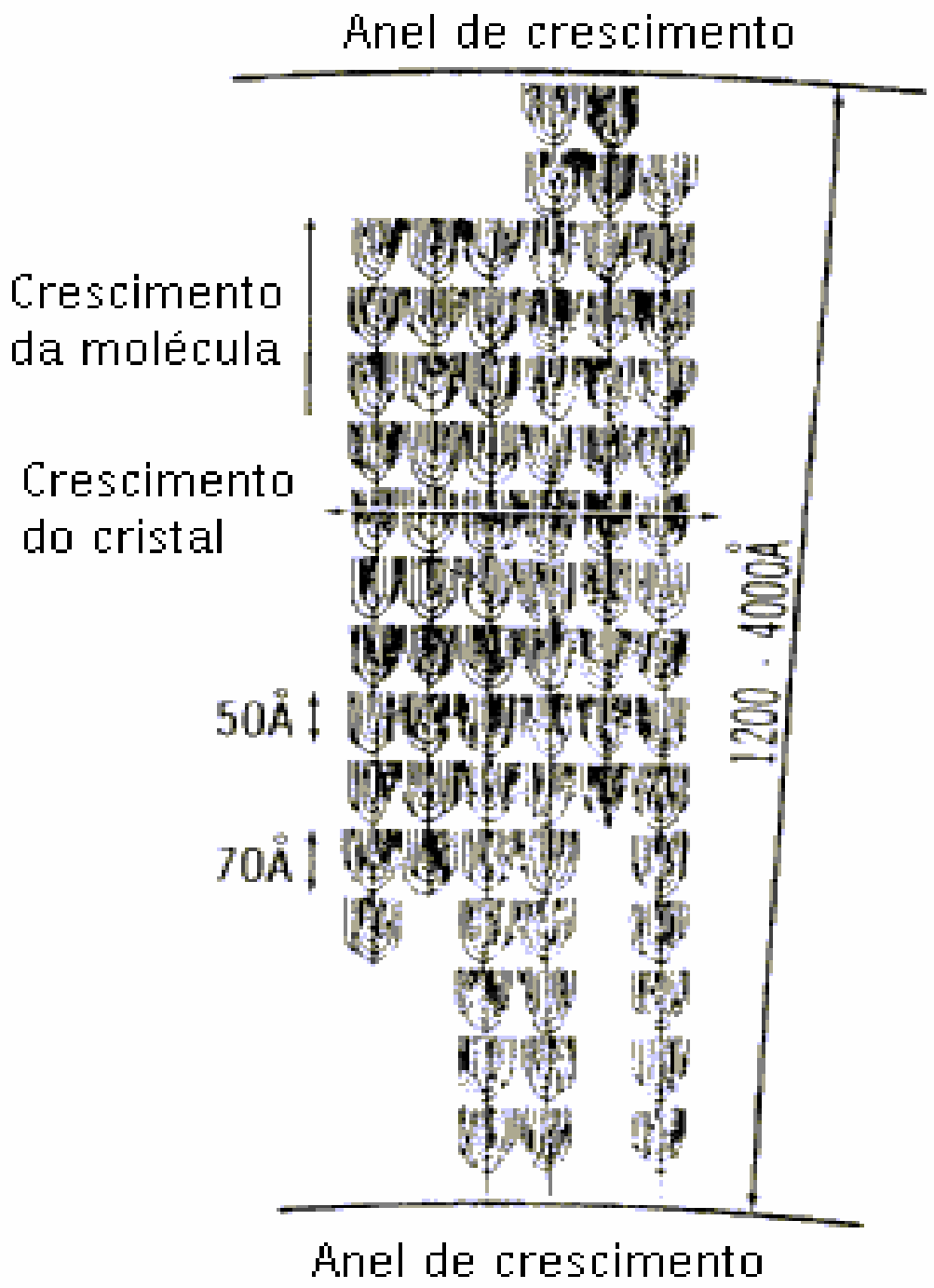

Figura 8 - Esquema do arranjo da molécula de amilopectina no anel de crescimento Fonte: French (1984)

\subsubsection{Padrão de cristalinidade}

Quando um cristal é irradiado com raios-x, os raios se dividem para formar um padrão distinto para a estrutura do cristal. Esta técnica é usada para estudar a natureza cristalina do amido (Figura 9). Por esse método foram identificados três padrões gerais de difração de raios-x em amido nativo. Amidos nativos de cereais 
como exemplo o de trigo, milho e arroz geram padrão A. Os amidos de tubérculos, como a batata, dão padrão $B$. Ervilha lisa e amidos de feijão geram padrão de $C$, que é uma forma de intermediária, provavelmente resultante da misturas dos tipos $\mathrm{A}$ e $\mathrm{B}$ (Thomas \& Atwell, 1999).

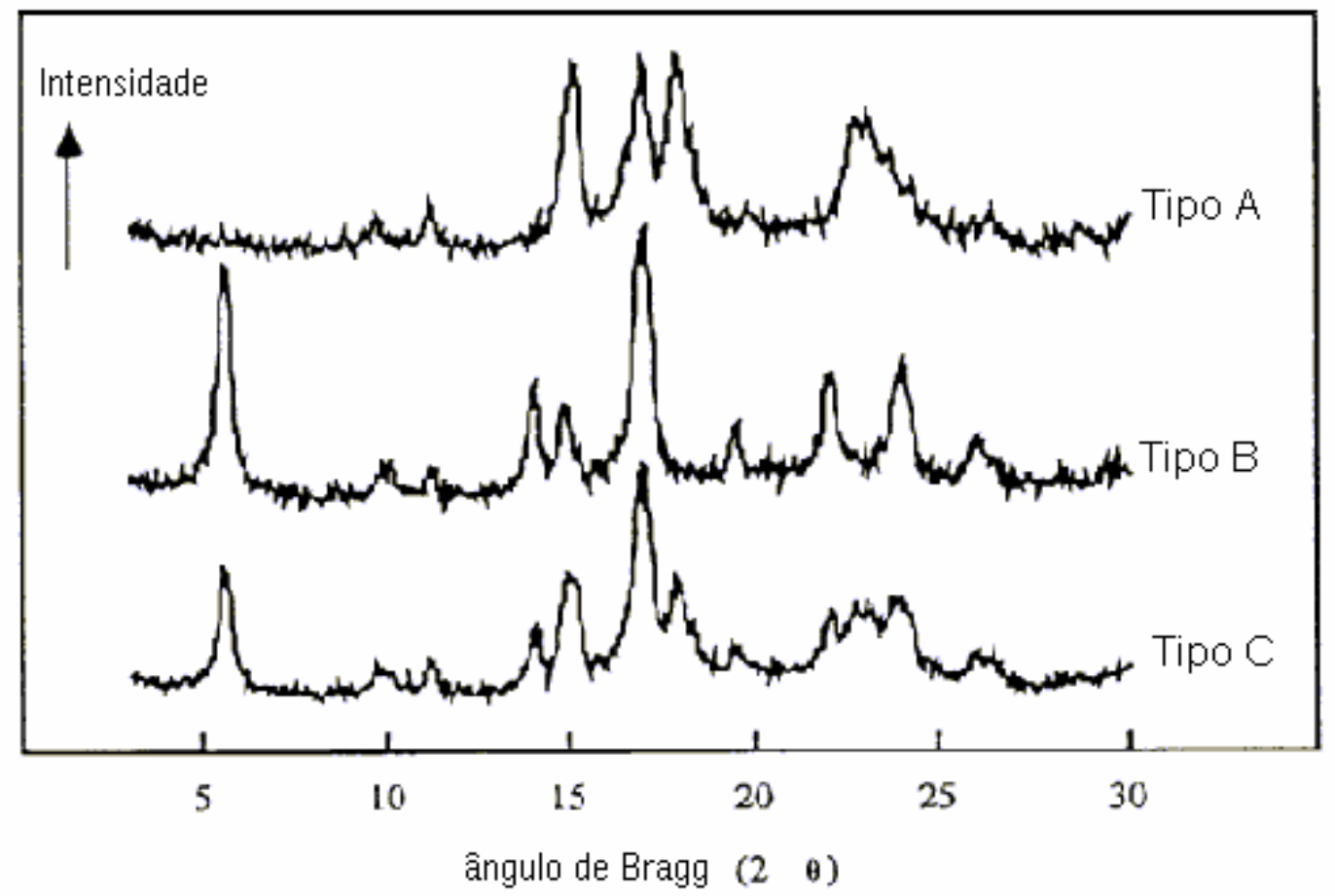

Figura 9 - Diagrama de difração de raios-x dos amidos de cristalinidade tipo A, B e C Fonte: Bertoline (1995)

Baseado na determinação da cristalinidade por raios- $x$, foram propostas estruturas detalhadas para o amido semi-cristalino. $O$ amido apresenta hélices duplas, com certa semelhança ao modelo proposto para a estrutura do DNA. Os modelos cristalinos para os padrões tipo A e B variam tanto com a quantidade de água que hidrata os resíduos de glicose como também com a densidade do empacotamento do arranjo cristalino (Thomas \& Atwell, 1999). 
Se o amido é recristalizado na presença de ácido graxo ou de álcool de cadeia longa, é obtido o padrão $\mathrm{V}$. O padrão $\mathrm{V}$ é atribuído a um amido complexo, no qual as cadeias de resíduos de glicose formam uma hélice com o exterior hidrofílico e um centro hidrofóbico, contendo uma molécula apolar como um lipídio (Thomas \& Atwell, 1999). Este tipo de estrutura é semelhante ao complexo de iodo-amido e sua estrutura geral é mostrada na Figura 10.

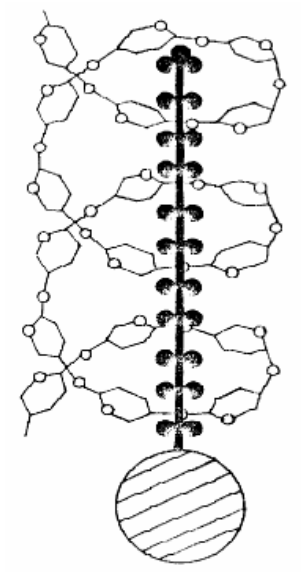

Figura 10 - Modelo simplificado para a estrutura de padrão V Fonte: Thomas \& Atwell (1999)

Ao contrário de Thomas \& Atwell (1999), Biliaderis (1991) afirma que o padrão A é característico de amidos de tubérculos, de raízes, de frutas, de milho com alto teor de amilose e de amidos retrogradados; o padrão B é característico de amidos de cereais e o padrão $C$ é característico em amidos de leguminosas.

Considerando que os grânulos de amido são parcialmente cristalinos, foram estabelecidos padrões específicos de difração de raios- $x$, variáveis com a fonte botânica. Nos difratogramas de raios- $x$, uma estimativa quantitativa das intensidades relativas das linhas de difração é dada pelas alturas dos picos. O ângulo de difração $2 \AA$, a partir do qual o espaço interplanar (d) é calculado, também pode ser facilmente 
obtido pelos gráficos de difração resultantes (Zobel, 1964). Os padrões de difração podem ser classificados em:

- $\quad$ Padrão A - Segundo Zobel (1988a), esse padrão apresenta picos fortes nos espaços interplanares (d) de 5,8; 5,2 e 3,8 $\AA$ (angstrons). Para Galant et al. (1982), esse padrão apresenta dois picos entre 8 e $9 \AA$ e um pico perto de $12 \AA$.

- $\quad$ Padrão B - Segundo Zobel (1988a), esse padrão apresenta pico forte de 15,8$16,0 \AA$, um pico com menor intensidade e mais largo a 5,9 c e um outro a 5,2 $\AA$, e um par de picos com intensidade de média a forte em 4,0-3,7 Å. Já segundo Galant et al. (1982), esse padrão apresenta um pico a $8,30 \AA$, dois picos a 11,30 e $12,0 \AA$ e um pico a $2,52 \AA$.

- $\quad$ Padrão C - é semelhante ao padrão A e apresenta um pico a mais em $16 \AA$. Segundo Zobel (1988a), o padrão C é uma estrutura distinta e não uma mistura dos padrões A e B. Já Gernat et al. (1990) concluíram que o padrão C é uma mistura de A e B e sendo assim, eles apresentam proporções de cada um nas partes cristalinas dos mesmos.

- $\quad$ Padrão V - conhecido como padrão hidratado e os picos aparecem em 12,0; 6,8 e 4,4 Å, o pico de 4,4 Å é normalmente usado como a primeira indicação de que o complexo V está sendo formado (Biliaderis, 1991; Zobel, 1988a,b).

Segundo Zobel (1964, 1988a), o padrão V é devido à formação de complexos de amilose com uma grande quantidade de moléculas orgânicas apolares.

Segundo Rosenthal et al. (1973) os amidos com padrão de difração de raios-x tipo A são os mais rapidamente são atacados pelas enzimas, o que segundo o autor, sugere heterogeneidade dentro do grânulo com regiões resistentes separadas por áreas mais abertas e acessíveis. Isso tem sido explicado através da existência de micelas cristalinas fortemente associadas que são separadas por regiões intermicelares, amorfas. Segundo os mesmos autores, os amidos que apresentam tipo A ou C são mais resistentes ao ataque enzimático, o que sugere grânulos mais homogêneos com relação à distribuição de forças internas de ligação.

Wu \& Sarko $(1978 a, b)$ propuseram uma estrutura cristalina para amilose A e B (Figura 11), baseadas em hélices duplas, de fios paralelos voltados para o lado direito, com 12 unidades glucosídicas por volta. $\mathrm{Na}$ unidade celular estas duplas hélices 
encontram-se empacotadas. A mesma conformação de duplas hélices de fios paralelos é encontrada nos polimorfos A e B. Entretanto, estes diferem no empacotamento cristalino das hélices e no teor de água. A amilose $A$ apresenta uma unidade celular ortorrômbica, com 8 moléculas de água e a amilose $B$ uma unidade celular hexagonal, com 36 moléculas de água ocupando um canal central. A estrutura C é simplesmente uma mistura das unidades celulares A e B e é portanto, intermediária entre as formas $A$ e $B$ na densidade de empacotamento. As estruturas $A$ e $B$ observadas nas fibras são idêntica às dos empacotamentos de amido correspondente.
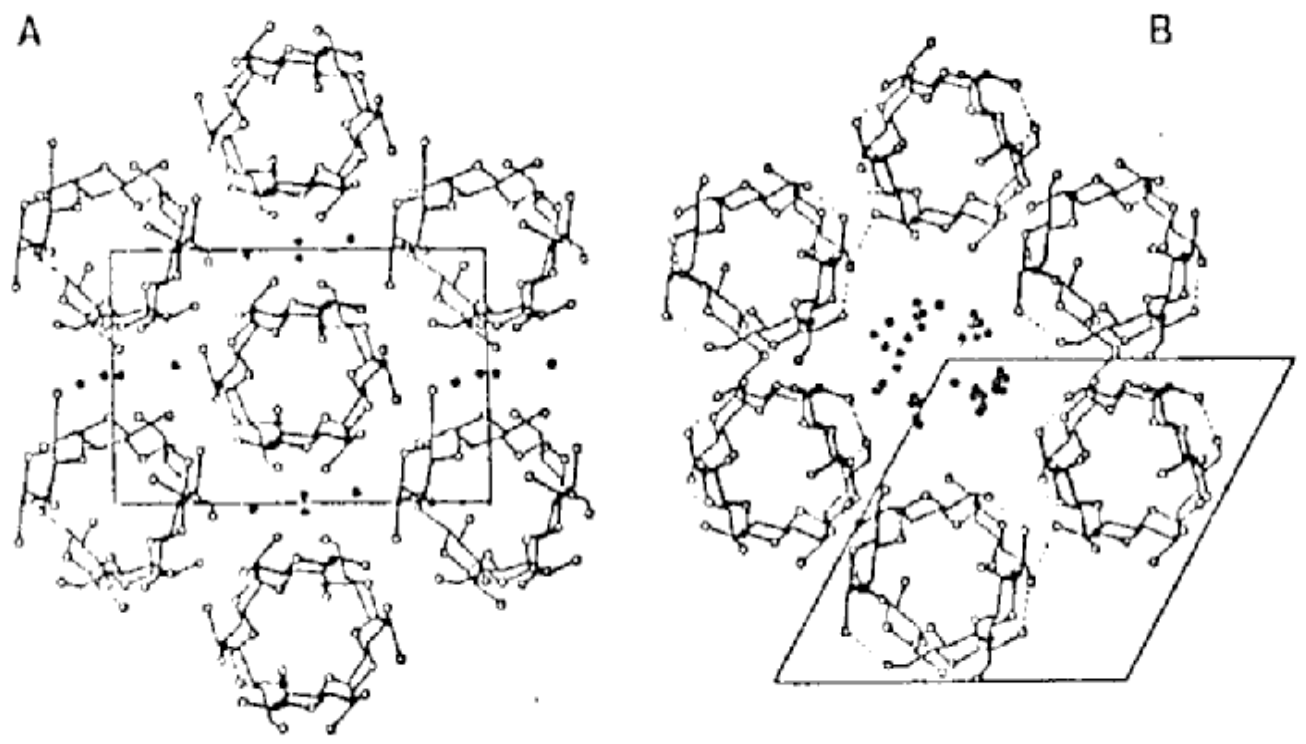

Figura 11 - Empacotamento cristalino das hélices duplas no tipo $A$ e no tipo $B$ e projeção da estrutura no plano

Fonte: Wu \& Sarko (1978a) 


\subsection{A gelatinização do amido}

O fenômeno de gelatinização ou gelificação do amido é extremamente importante para vários sistemas alimentícios.

Grânulos de amido nativos são insolúveis em água abaixo de sua temperatura de gelificação. Eles expandem um pouco em água fria (10-20\%), devido à difusão e absorção de água dentro das regiões amorfas, entretanto, esta expansão é reversível pela secagem (Biliaderis, 1991). De acordo com Morrison (1995), nas zonas amorfas os componentes que expandem são a amilose e um pouco de amilopectina. Essa expansão é limitada por ser severamente restringida pelas camadas essencialmente contínuas de amilopectina cristalina. Este autor considera que esse grau de expansão seja reversível porque as camadas cristalinas não são perturbadas.

Segundo Bermudez (1997)2 , citado por Franco et al. (2001), a temperatura de gelificação da batata-doce é da faixa de $61,1-86,0^{\circ} \mathrm{C}$ e da mandioquinha-salsa variando de 58,6 a $58,8^{\circ} \mathrm{C}$.

\subsection{Ação de enzimas sobre o amido}

Os ensaios enzimáticos têm sido usados para mostrar a existência de ligações associativas no interior dos grânulos de amido (Rosenthal et al., 1973). As enzimas a serem utilizadas para este fim devem ser concentradas, purificadas (Franco et al., 2001).

A hidrólise se dá por desdobramento total das moléculas de amilose ou amilopectina, que, ao se romperem transformam-se em dextrinas cada vez mais simples e finalmente em glucose. O amido não tem sabor, mas os produtos de uma hidrólise intensa apresentam sabor adocicado (Franco et al., 2001).

Há basicamente cinco grupos de enzimas envolvidos com hidrólise do amido. As endo- e exoamilases agem primeiramente nas ligações $\alpha-1,4$, ao passo que as enzimas desramificadoras agem exclusivamente nas ligações $\alpha-1,6$. Um quarto grupo

\footnotetext{
${ }^{2}$ Bermudez, op. cit., p.11.
} 
são as isomerases, que agem nos xaropes de glucose para convertê-los em xaropes de frutose.

E finalmente, as ciclodextrinas glicosil-transferases, que degradam amido pela catalisação de reações de despolimerização e de ciclização. As ações dessas enzimas nos amidos estão ilustradas esquematicamente na Figura 12.

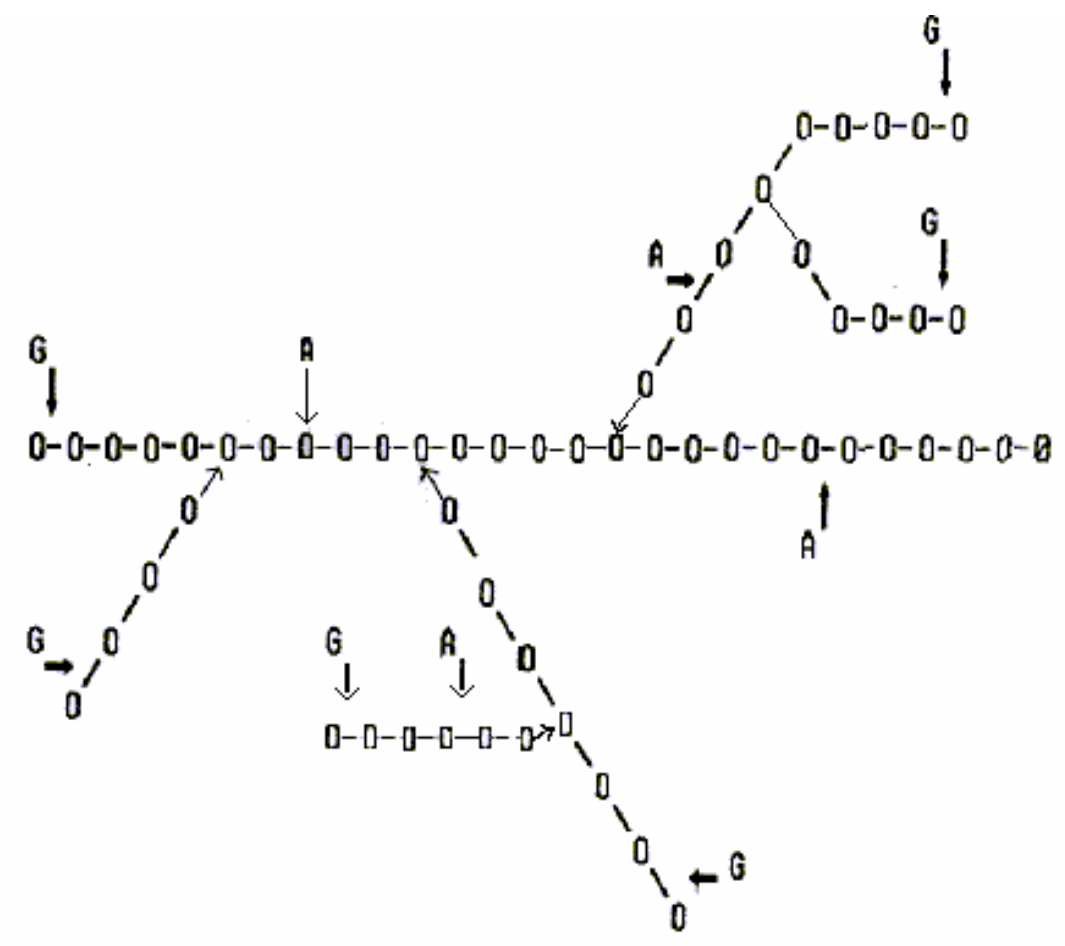

Figura 12 - Ação das enzimas amilolíticas sendo A: $\alpha$-amilase; G: amiloglucosidase; ø: extremidade redutora

Fonte: adaptado de Guzmán-Maldonado e Paredes-Lópes (1995)

Há um outro grupo de enzimas, as amilases formadoras de oligossacarídeos, como maltotriose, maltotetrose, maltopentose e maltohexose. Embora a produção de tais enzimas não seja explorada comercialmente em larga escala, o uso dessas amilases com ação externa específica representa uma área de interesse no campo de enzimologia de amido (Guzmán-Maldonado \& Paredes-Lópes, 1995). 


\subsubsection{Ação da alfa-amilase}

As alfa-amilases são enzimas que quebram as ligações glicosídicas $\alpha-1,4$ na amilose, na amilopectina e em polissacarídeos relacionados, mas não quebram as ligações $\alpha-1,6$ em amilopectinas. Os produtos da hidrólise apresentam moléculas de tamanhos variados e possuem a configuração a no carbono $C_{1}$ na unidade de glucose redutora produzida. Elas atuam nas ligações das regiões internas do substrato e por isso causam um rápido decréscimo da viscosidade de amidos gelatinizados (Figura 13). Há duas variedades de endoamilases (EC3.2.1.1), as termoestáveis e as termolábeis. As alfa-amilases termoestáveis são de origem bacteriana e derivam de Bacillus species (Guzmán-Maldonado \& Paredes-Lópes,1995).

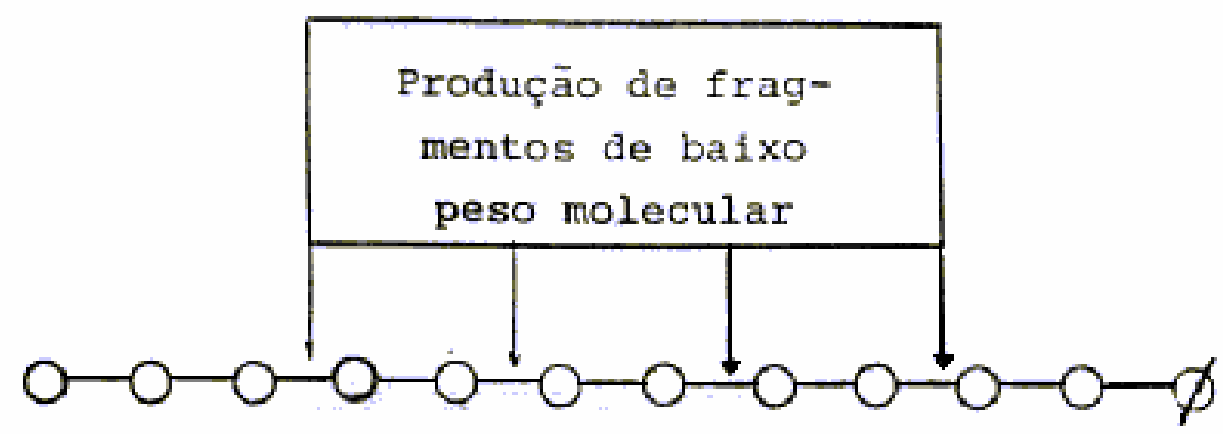

Figura 13 - Ação da alfa-amilase em moléculas de amido Fonte: Franco (1986)

French (1975) descobriu que a a-amilase se caracteriza por atacar tanto a amilose quanto a amilopectina. Em primeiro lugar a enzima forma com o substrato um complexo, independentemente da posição inicial do substrato. O complexo enzimasubstrato formado possui uma conformação ideal para a catálise. A ligação da direita está mais fracamente associada à enzima que a da esquerda, por isso a ligação da direita se dissocia deixando este lugar desocupado. $O$ fragmento da esquerda se rearranja para ocupar todo o lugar da ligação, este processo produz um complexo enzima-substrato com geometria ideal para as catálises posteriores. Como a $\alpha$ amilase não consegue quebrar as ramificações, a hidrólise da amilopectina é limitada, 
isso produz dextrinas limites ou oligossacarídeos, que possuem todos os pontos de ramificação.

O padrão de atuação da enzima $\alpha$-amilase produz inicialmente $\mathrm{G}_{5}$ (o tamanho da cadeia é expresso em número de glicoses) em grande quantidade, seguidos de $\mathrm{G}_{3}$, $\mathrm{G}_{2}, \mathrm{G}_{1}$ e $\mathrm{G}_{4}$ em ordem decrescente. A taxa de hidrólise aumenta muito com o aumento do tamanho da cadeia; $G_{2}$ e $G_{3}$ não são praticamente atacados. O modelo de MichaelMentem é suficiente para explicar a cinética para baixas concentrações de amido, entretanto, um modelo modificado de primeira ordem foi necessário para altas concentrações. Não há evidências da inibição do substrato pela alta concentração de amido (Guzmán-Maldonado \& Paredes-Lópes, 1995).

As amilases de uma maneira geral, agem na superfície do grânulo de amido, provavelmente em uma imperfeição estrutural ou fissura, e depois estendem-se lateralmente formando cavidades cônicas. A ação contínua da alfa-amilase causa erosão nos grânulos que podem ser, eventualmente, dissolvidos completamente (French, 1975).

\subsubsection{Ação da amiloglucosidase}

stas enzimas atuam nos mesmos substratos que as endoamilases, mas de forma diferenciada. Algumas podem quebrar as ligações $\alpha-1,6$ (Figura 14), mas a taxa de reação é lenta quando comparada com a hidrólise das ligações $\alpha-1,4$. As exoamilases atuam externamente nas ligações dos substratos a partir das extremidades não redutoras produzindo produtos com baixo peso molecular (GuzmánMaldonado \& Paredes-Lópes, 1995). 

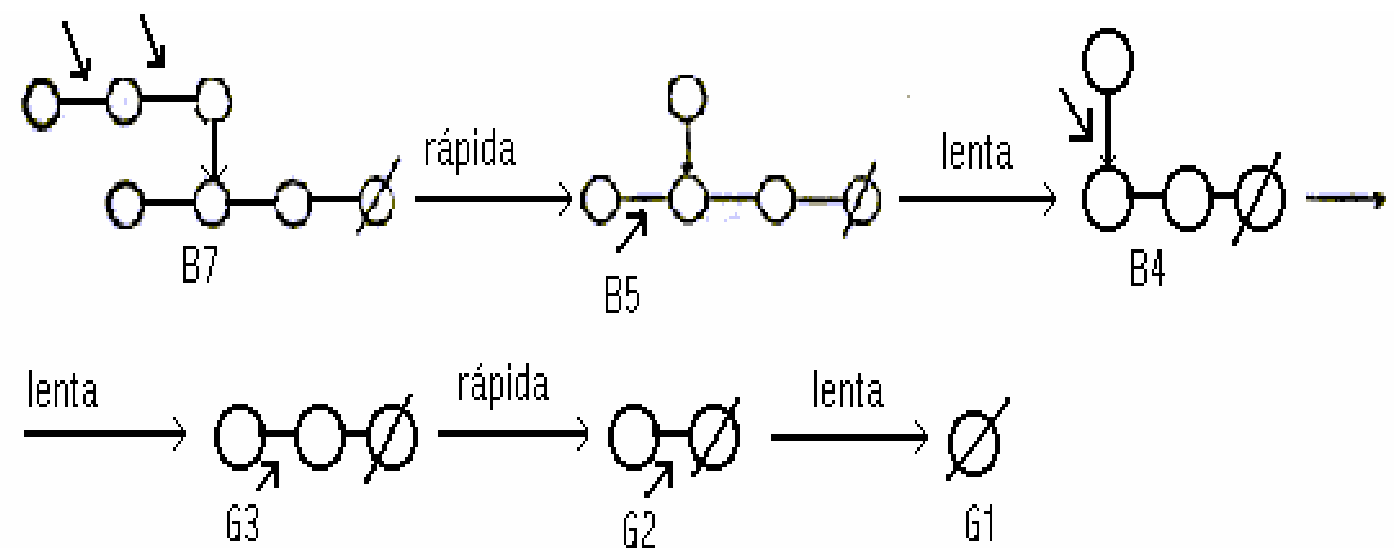

Figura 14 - Ação da amiloglucosidase em oligossacarídeos ramificados Fonte: Franco (1986)

O uso mais importante da glucoamilase é a produção de xaropes com alto teor de glicose (de 96 a 98\% de glicose), e de xaropes de alta frutose (55\% de frutose). Em altas concentrações de glucose a amiloglucosidase repolimeriza essas moléculas em uma reação chamada de reversão formando maltose e isomaltose. Esse fenômeno é mais pronunciado quando existe alta concentração de enzimas e de substratos. A reação de polimerização de glucose também pode ser catalisada por outra enzima, a transglucosidase (EC 2.4.1.24), a qual está freqüentemente presente em preparações de amiloglucosidase não refinadas (Guzmán-Maldonado \& Paredes-Lópes, 1995).

\subsubsection{Ação conjunta da alfa-amilase e amiloglucosidase}

A amiloglucosidase desempenha o papel principal na hidrólise do amido in natura e quando associada com a alfa-amilase apresenta um grande efeito sinergístico (Abe et al., 1988).

Segundo Ueda et al. (1974), misturas de enzimas contendo alfa-amilase e amiloglucosidase foram mais efetivas quanto à hidrólise do amido que aquelas contendo isoamilase e amiloglucosidase. Baseado nesses resultados, os autores sugeriram que a existência de amilose no amido pode impedir a digestão no grânulo 
pela amiloglucosidase sozinha, enquanto a presença de alfa-amilase propicia a hidrólise desse componente evitando a inibição da amiloglucosidase.

A ação sinergística da amiloglucosidase e a-amilase para hidrólise do amido é retardada apenas pelo decréscimo do peso molecular do substrato, mas em compensação é incrementada pelo aumento da concentração de substrato (GuzmánMaldonado \& Paredes-Lópes, 1995).

\subsection{Tratamento térmico do amido em baixos teores de umidade}

As propriedades de pasta dos amidos já são atualmente conhecidas, no entanto as modificações que ocorrem em condições de altas temperaturas e baixa umidade ainda não são totalmente conhecidas.

O tratamento com calor e baixa umidade é um processo que apresenta como parâmetros críticos de controle o teor de umidade, a temperatura e o tempo de aquecimento (Tester \& Debon, 2000). Os primeiros estudos de TCBU foram feitos com amido de batata-doce com a intenção de tornar suas propriedades mais parecidas com às do amido de milho e substituí-lo nos períodos de escassez do mesmo (Stute, 1992).

O tratamento com calor e baixa umidade usa baixos valores de umidade, abaixo de $35 \%$ e temperaturas acima da temperatura de transição vítrea e da temperatura de gelatinização, variando de 84 a $120^{\circ} \mathrm{C}$. O tempo pode variar de 15 minutos a 16 horas. Nessas condições ocorrem alterações no padrão de difração de raios- $x$, na cristalinidade, nas interações entre as cadeias, no intumescimento dos grânulos, na viscosidade e também na suscetibilidade à hidrólise enzimática e ácida. Entretanto não ocorrem alterações morfológicas passíveis de serem observadas ao microscópio eletrônico de varredura (Gunaratne \& Hoover, 2002).

As alterações diferem com a fonte botânica. Segundo Gunaratne \& Hoover (2002) os amidos de tuberosas são mais suscetíveis ao tratamento do que os amidos de cereais ou leguminosas. Os autores afirmam que amidos de tuberosas tropicais que apresentam propriedades funcionais limitantes podem ter as aplicações ampliadas quando submetidos a esse tratamento. 
Muhrbeck (1996) estudando o tratamento com calor e baixa umidade (27\% de umidade a $100^{\circ} \mathrm{C} / 16 \mathrm{~h}$ ) observou que o padrão de cristalinidade do amido de batata passou do tipo B para A. Leach et al. (1959) também relataram essa alteração quando submeteram o amido de batata ao tratamento nas condições de umidade variando de 20 a $25 \%$ e temperatura de $100^{\circ} \mathrm{C}$. Em ambos os casos não foi possível identificar microscopicamente alguma mudança não ocorrendo também perda da birrefringência. Os autores relataram grande redução do poder de inchamento dos grânulos e de sua solubilidade, as pastas obtidas apresentaram reologia curta, aspecto opaco e quando resfriadas, formavam géis rígidos muito parecidos com os géis de amido de milho. $A$ conclusão foi que o tratamento promoveu uma recristalização do amido tornando-o parecido com o amido de milho.

Lorenz \& Kulp (1982) estudaram o efeito do tratamento térmico sob baixa umidade $\left(100^{\circ} \mathrm{C} / 16\right.$ horas $/ 27 \%$ umidade) sobre os amidos de mandioca e araruta e observaram que a suscetibilidade enzimática e a capacidade de absorção de água desses amidos foram aumentadas. Os autores observaram também pelos difratogramas de raios-x uma diminuição no grau de cristalinidade dos amidos de cereais e mudanças de padrões $C$ para $A$.

Franco \& Ciacco (1995) observaram diferentes comportamentos quanto à suscetibilidade enzimática dos amidos de milho e mandioca tratados térmicamente sob baixa umidade com diferentes condições. A primeira condição foi com umidade a $27 \%$, a $100^{\circ} \mathrm{C}$ por 16 horas, nessa condição houve aumento da suscetibilidade à hidrólise enzimática o que pode ter sido causado por rompimento e posterior rearranjo das interações dentro dos grânulos provocando um certo grau de degradação do amido e aumento das regiões acessíveis às enzimas. A segunda condição apenas variou a umidade para $18 \%$. Nessa condição provavelmente houve um aumento da cristalinidade dos grânulos resultando na diminuição da suscetibilidade à hidrólise enzimática.

Gunaratne \& Hoover(2002) concluíram que o TCBU promove a interação das cadeias poliméricas, através do rompimento da estrutura cristalina e dissociação das estruturas de duplas hélices na região amorfa e posterior rearranjo dos cristais rompidos durante o tratamento. Para todos os amidos estudados (Taro, Mandioca e Batata) por esses autores o processamento TCBU $\left(100^{\circ} \mathrm{C} / 10 \mathrm{horas} / 30 \%\right.$ umidade) aumentou a suscetibilidade enzimática quando usado $\alpha$-amilase pancreática no 
máximo em $455 \%$ para a batata e no mínimo de $19 \%$ para o amido de taro). A quebra dos cristais de amido perto da superfície pode facilitar a adsorção da alfa-amilase no interior do grânulo, fato que pode explicar o aumento significativo na porcentagem de hidrólise dos amidos tratados com TCBU. Os autores também afirmam que mesmo quando os cristais não são quebrados pelo tratamento o aumento suscetibilidade ocorre devido a dois fatores. Primeiro devido ao número de hélices duplas rompidas pelo tratamento com TCBU nas regiões amorfas dos grânulos, que facilita o acesso das enzimas aos sítios da cadeia. Segundo, devido à interação que ocorre entre as cadeias de amilose durante o rearranjo das cadeias poliméricas.

Collado \& Corke (1999) afirmam que o tratamento com calor e baixa umidade pode ser usado pelas as indústrias para criar novos produtos. Um exemplo de uso seria em alimentos infantis aonde não é permitido o uso de amidos modificados por agentes químicos. 


\section{MATERIAL E MÉTODOS}

O presente experimento foi desenvolvido no Laboratório de Amido e Produtos Amiláceos, da Escola Superior de Agricultura Luiz de Queiroz, Universidade de São Paulo, em Piracicaba- SP.

\subsection{Material}

Os amidos utilizados no presente estudo foram extraídos de batata-doce de polpa branca, gengibre e mandioquinha-salsa. Estas tuberosas foram adquiridas no CEASA de Piracicaba-SP, em junho de 2002. As fotos dessas matérias-primas utilizadas são apresentadas na Figura 15.

As enzimas utilizadas foram a a-amilase de Bacillus sp (A6380) e a amiloglucosidase de Rhizopus mold (A7420), ambas da SIGMA.

Todos os reagentes utilizados no experimento foram puros para análise.

\subsection{Métodos}

\subsubsection{Extração do amido das tuberosas amiláceas}

As extrações foram realizadas cuidadosamente, evitando procedimentos que segundo a literatura pudessem alterar a estrutura dos grânulos. Foram realizadas três extrações distintas de cada fonte vegetal. 
(A)

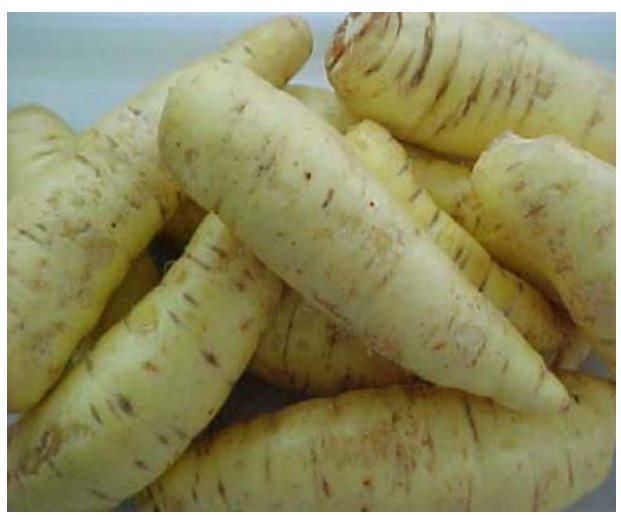

(B)

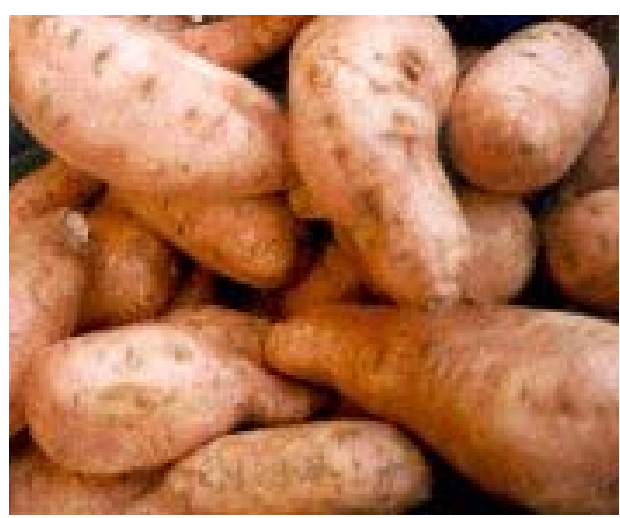

(C)

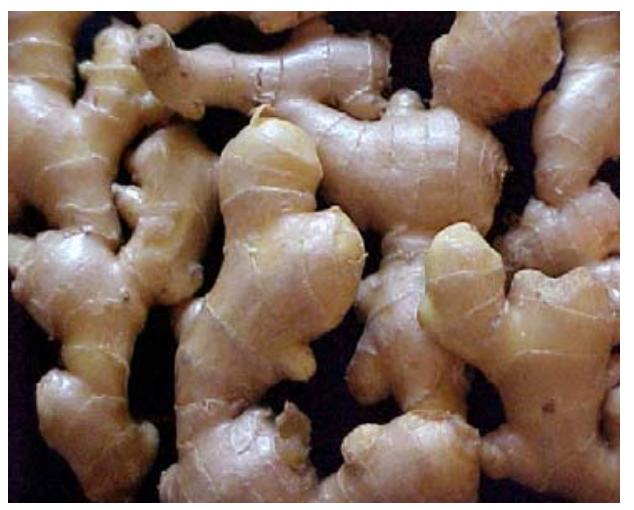

Figura 15 - Aspecto das tuberosas utilizadas para extração do amido sendo (A) mandioquinha-salsa, (B) batata-doce, (C) gengibre 


\subsubsection{Extração do amido de mandioquinha-salsa}

A extração do amido de mandioquinha-salsa foi efetuada conforme Sarmento (1997), com algumas modificações, conforme Figura 16. A adição de água gelada foi utilizada como recurso para evitar o escurecimento enzimático do material.

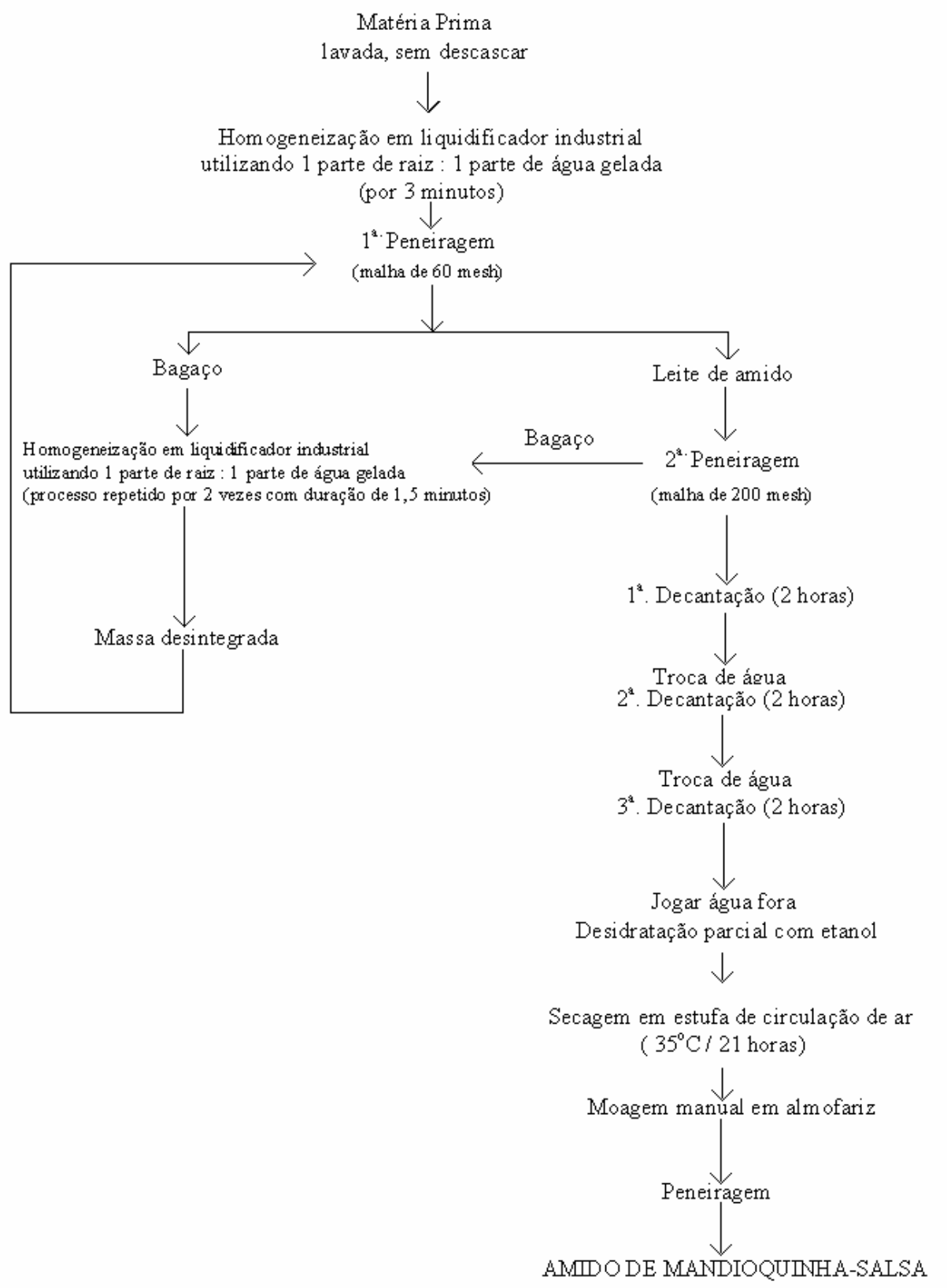

Figura 16 - Fluxograma do processo de extração do amido de mandioquinha-salsa 


\subsubsection{Extração do amido de batata-doce}

A extração do amido de batata-doce foi efetuada conforme Sarmento (1997), com algumas modificações, conforme Figura 17. A adição de água gelada foi feita para se evitar o escurecimento enzimático do material.

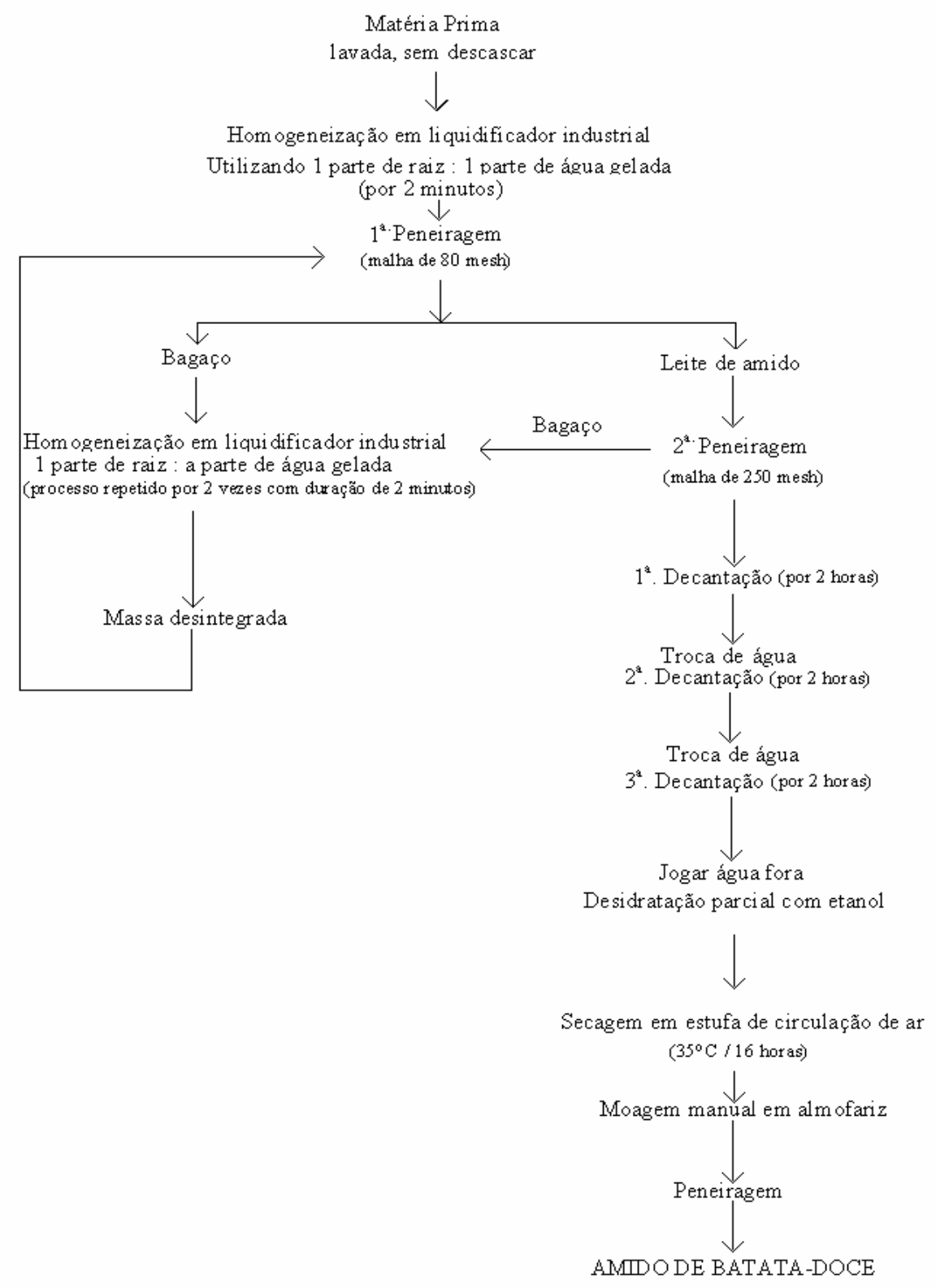

Figura 17 - Fluxograma do processo de obtenção do amido de batata-doce 


\subsubsection{Extração do amido de gengibre}

A extração do amido de gengibre foi realizada de acordo com Sarmento (1997), com algumas modificações, conforme Figura 18.

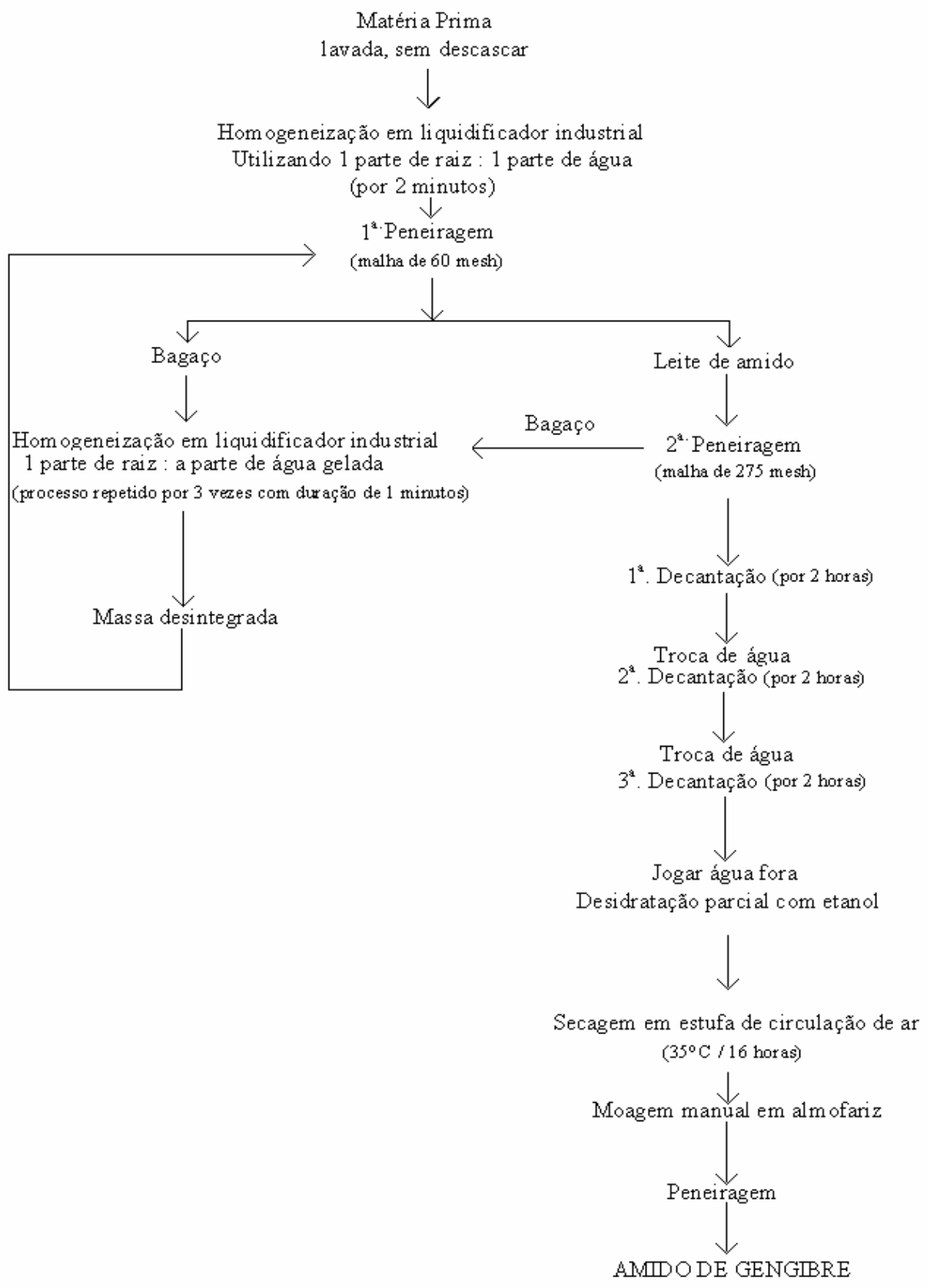

Figura 18 - Fluxograma do processo de obtenção do amido de gengibre 


\subsubsection{Composição dos amidos extraídos}

Os amidos das diversas fontes estudadas foram avaliados quanto à acidez e à composição química.

\subsubsection{1 pH}

$\mathrm{O} \mathrm{pH}$ foi determinado usando o método descrito pelas normas analíticas do Instituto Adolfo Lutz (IAL, 1985).

\subsubsection{Umidade}

O teor de umidade dos amidos foi determinado em estufa com circulação de ar a $105^{\circ} \mathrm{C}$ até peso constante, segundo o método da AOAC (1994).

\subsubsection{Lipídeos}

O teor de lipídeos foi determinado utilizando-se extrator Soxleth e hexano como solvente, segundo o método descrito pela AOAC (1994).

\subsubsection{Cinza}

O conteúdo de cinza foi determinado após calcinação em mufla por 2 horas a $550^{\circ} \mathrm{C}$, segundo o método descrito pela AOAC (1994). 


\subsubsection{Proteína}

O teor de nitrogênio dos amidos foi determinado pelo método de microKjeldahl segundo o método da AOAC (1994). O fator utilizado na conversão do teor de nitrogênio para proteína bruta foi de 6,25.

\subsubsection{Amilose}

O teor de amilose aparente foi determinado usando a metodologia ISO6647 (International Organization for Standardization, 1987).

\subsubsection{Fósforo}

O teor deste mineral foi determinado após digestão nitroperclórica da amostra, como preconizado por Sarruge \& Haag (1974), seguido de determinação espectrofotométrica.

\subsubsection{Formato e tamanho dos grânulos de amido}

Os grânulos de amidos isolados foram avaliados quanto ao formato e tamanho por Análise de Imagem. As amostras de amido foram coletadas com fio de platina e misturadas, sobre lâminas de vidro, com duas gotas de água destilada e, posteriormente, cobertas com lamínula. As lâminas foram observadas em microscópio óptico Zeiss (MC-80) e as imagens selecionadas foram analisadas pelo software KS300 da Zeiss. Foram tomadas medidas de 600 grânulos. Como os grânulos de amido, em sua maioria, apresentaram formato irregular, foram tomadas duas medidas, uma do diâmetro maior e outra do diâmetro menor e também calculada a área superficial aparente. 


\subsubsection{Tratamento do amido com calor em baixa umidade}

O tratamento com calor e baixa umidade foi feito seguindo a metodologia de Collado \& Corke (1999) nas condições de $27 \%$ de umidade e $100^{\circ} \mathrm{C}$ de temperatura por 16 horas. A quantidade de água para se atingir a umidade necessária foi calculada através da Fórmula 1.

$$
H=[(100-I) /(100-D)-1]^{*} Q
$$

Onde:

$\mathrm{H}=$ quantidade de água adicionada em $\mathrm{mL}$;

I = umidade inicial da amostra;

$\mathrm{D}=$ umidade desejada;

$\mathrm{Q}=$ quantidade de amostra em $\mathrm{g}$.

Após o acerto de umidade das amostras para $27 \%$, as mesmas foram acondicionadas em placas de Petri , fechadas hermeticamente por fitas adesivas e submetidas a estufa por 16 horas, a $100^{\circ} \mathrm{C}$. O material resultante deste tratamento foi avaliado quanto ao aspecto geral por microscopia eletrônica de varredura, suscetibilidade enzimática, difração de raios-x e propriedades da pasta.

\subsubsection{Digestão enzimática dos grânulos de amido}

A suscetibilidade enzimática dos grânulos de amido natural e tratado por calor em baixa umidade (TCBU) foi avaliada utilizando-se as enzimas alfa-amilase de Bacillus sp e amiloglucosidase de Rhizopus mold. Primeiramente foi avaliada a atividade de cada uma dessas enzimas. 


\subsubsection{Atividade da alfa-amilase bacteriana}

A atividade da $\alpha$-amilase bacteriana foi determinada utilizando-se como base a medida do tempo que a enzima requer para hidrolisar o grânulo de amido a um tamanho pré definido de dextrina, o tamanho foi indicado pela coloração dada pelo complexo dextrina-iodo, em relação a uma solução de cor padrão que é dada pela mistura $25 \mathrm{~g}$ de cloreto de cobalto hexahidratado, $3,84 \mathrm{~g}$ de dicromato de potássio em $100 \mathrm{~mL}$ de ácido clorídrico 0,01N, segundo metodologia de Sandsted et al. (1939).

Foi adicionada uma alíquota de $1 \mathrm{~mL}$ de solução aquosa da enzima a $20 \mathrm{~mL}$ de uma solução aquosa de amido solúvel a $2 \%(p / v)$ em solução de tampão acetato, $0,1 \mathrm{M}, \mathrm{pH} 6,0$. O volume foi completado para $30 \mathrm{~mL}$ com água destilada e colocamos a solução em banho-maria na temperatura de $30^{\circ} \mathrm{C}$.

Para acompanhar a coloração, foram retiradas alíquotas de $1 \mathrm{~mL}$ da solução que estava em banho-maria e estas, foram adicionadas a $5 \mathrm{~mL}$ de uma solução diluída de iodo-iodeto de potássio ( $11 \mathrm{~g}$ de $\mathrm{KI}$ e $5,5 \mathrm{~g}$ de $\mathrm{I}_{2}$ em $500 \mathrm{~mL}$ de $\mathrm{H}_{2} \mathrm{O}$ ) até que a coloração ficasse igual a da solução padrão de $\mathrm{CoCl}_{2}$ e $\mathrm{K}_{2} \mathrm{Cr}_{2} \mathrm{O}_{7}$ em $\mathrm{HCl} 0,01 \mathrm{~N}$. A atividade da alfa-amilase foi calculada pela fórmula (2) desenvolvida por Sandsted et al. (1939), e o valor foi expresso em unidades de SKB.

$$
\begin{gathered}
\text { Unidades } S K B=\underline{m \times t} \\
G \times t_{c}
\end{gathered}
$$

Onde:

$\mathrm{m}=$ peso do amido em gramas;

$\mathrm{t}=60$ minutos;

$\mathrm{g}=$ gramas de enzima $/ \mathrm{mL}$;

$t_{c}=$ tempo de incubação em minutos que deu a leitura da coloração. 


\subsubsection{Atividade da amiloglucosidase fúngica}

A atividade da enzima amiloglucosidase fúngica foi determinada pelo método de Ueda et al. (1980), com algumas modificações.

Foram utilizados $2,5 \mathrm{~mL}$ de uma solução a $1 \%(\mathrm{p} / \mathrm{v})$ de amido solúvel (Merck) fervida, adicionados de $0,5 \mathrm{~mL}$ da solução tampão acetato $0,05 \mathrm{M} \mathrm{em} \mathrm{pH} \mathrm{4,5,} 0,5 \mathrm{~mL}$ de água deionizada e também $0,5 \mathrm{~mL}$ de solução da enzima, que resultou em um volume final de $4,0 \mathrm{~mL}$. A solução foi incubada à temperatura de $55^{\circ} \mathrm{C}$ pelo período de 10 minutos, após o que, $1 \mathrm{~mL}$ dessa solução foi retirada e os açúcares redutores que foram produzidos foram medidos pelo método do DNS (3,5-ácido dinitrosalicílico) seguindo o método proposto por Miller (1959).

Foi definido que uma unidade de atividade de amiloglucosidase é a quantidade necessária para produzir $1 \mathrm{~mL}$ de glicose $/ \mathrm{mL}$ da mistura de reação sob as condições aqui descritas.

\subsubsection{Digestão enzimática dos grânulos de amido}

Os amidos naturais e os tratados por calor em baixa umidade foram submetidos a processo de digestão enzimática segundo a metodologia de Leach et al. (1963), com algumas modificações. Cinco gramas (base seca) de amido foram suspensas em $88 \mathrm{~mL}$ de solução tampão fosfato $0,05 \mathrm{M}, \mathrm{pH}$ 6,0. Em seguida 100 unidades SKB/g de amido de alfa-amilase de Bacillus e 50 unidades/g de amido de amiloglucosidase fúngica foram adicionadas. Para evitar crescimento microbiano foi adicionado $1 \mathrm{~mL}$ de tolueno à mistura, antes de ser incubada a $37^{\circ} \mathrm{C}$ por um período de 24 horas, sob agitação constante de 150rpm. Durante esse período foram retiradas alíquotas de $1 \mathrm{~mL}$ nos tempos 1 hora, 3 horas, 5 horas, 7 horas e 24 horas de digestão para a dosagem de açúcares redutores (Somogy (1945) \& Nelson (1944)). Com esses valores foram construídas as curvas cinéticas da hidrólise. Após o período de 24 horas as enzimas foram inativadas pela adição de $10 \mathrm{~mL}$ de etanol. O material foi filtrado em filtro com porosidade de $0,22 \mu \mathrm{m}$ (Millipore GSWP, Ireland) e lavado com três porções de $10 \mathrm{~mL}$ de etanol, $5 \mathrm{~mL}$ de acetona e seco em estufa a $37^{\circ} \mathrm{C}$. 
A porcentagem de hidrólise foi calculada através da Fórmula (3).

$$
H=\underline{P l}-P D \times 100
$$

$\mathrm{PI}$

Onde:

$\mathrm{H}=\%$ de hidrólise;

$\mathrm{PI}=$ Peso do amido inicial $(\mathrm{g})$;

$\mathrm{PD}=$ Peso do amido após hidrólise (g).

\subsubsection{Características dos grânulos e pastas de amidos tratados e não tratados pela alfa-amilase e amiloglucosidase}

\subsubsection{Microscopia eletrônica de varredura}

A morfologia dos grânulos e o perfil de ataque enzimático das amostras neste experimento foram observados ao microscópio eletrônico de varredura (MEV), marca ZEISS DSM 940A. A montagem das amostras foi feita em suportes (stubs) com fita adesiva dupla face, onde os amidos foram fixados e cobertos com uma fina camada de ouro em metalizador Balzers. 


\subsubsection{Difração por raios-X}

Após pernoitar em câmara saturada com água, as amostras de amido foram compactadas em suportes específicos e submetidos a um difratômetro de raios- $x$ da marca Phillips, com anodo de cobre (CuK $\alpha-1,54 \AA$ ), operando no intervalo 3 a 50 ${ }^{\circ} 2 \theta$, para avaliação da cristalinidade dos grânulos. As análises foram feitas segundo Gunaratne \& Hoover (2002) usando velocidade de varredura de $1,2 \AA 2 \theta / \mathrm{min}$ e condições de trabalho de $40 \mathrm{kv}$ e $40 \mathrm{~mA}$. Os perfis de difração de raios-x foram classificados de acordo com os padrões de Zobel (1964).

\subsubsection{Propriedades de pasta dos amidos}

As propriedades de pasta dos amidos isolados foram avaliadas em aparelho Rapid Visco Analyser (RVA), série 4, da Newport Scientific, na concentração de 2,5g/25 mL de água. Para o cálculo desta concentração foram efetuadas correções na quantidade de amido a ser pesada e na quantidade de água a ser adicionada ( $25 \mathrm{~mL}$ antes da correção), segundo tabela de correção fornecida pelo fabricante (Newport Scientific, 1998), tomando como base um teor de umidade de 14\%, para se obter um peso seco de amido de 2,5g. Foi utilizada a programação Std 2 (Standard Analysis 2) do software Thermocline for Windows, versão 2.2, para proceder a análise, segundo o Figura 19.

$\mathrm{Na}$ análise dos resultados obtidos para temperatura de pasta por este programa foi feita correção na fórmula, de TempAtViscRate $(1 ; 13 ; 1 ; 24)$ para TempAtViscRate $(1 ; 13 ; 1 ; 6)$. As unidades de viscosidade geradas pelo equipamento são arbitrárias, em RVU, ou seja, Rapid Visco Units. Os resultados foram interpretados a partir dos gráficos plotados pelo programa e os parâmetros avaliados no presente trabalho são apresentados na Figura 20.

\begin{tabular}{|l|l|l|}
\hline TEMPO & TIPO & VALOR \\
\hline
\end{tabular}




\begin{tabular}{|c|c|c|}
\hline (Hora: Minuto: Segundo) & & \\
\hline $00: 00: 00$ & Temperatura & $50^{\circ} \mathrm{C}$ \\
\hline $00: 00: 00$ & Velocidade & $960 \mathrm{rpm}$ \\
\hline $00: 00: 00$ & Velocidade & $160 \mathrm{rpm}$ \\
\hline $00: 01: 00$ & Temperatura & $50^{\circ} \mathrm{C}$ \\
\hline $00: 08: 30$ & Temperatura & $95^{\circ} \mathrm{C}$ \\
\hline $00: 13: 30$ & Temperatura & $95^{\circ} \mathrm{C}$ \\
\hline $00: 21: 00$ & Temperatura & $50^{\circ} \mathrm{C}$ \\
\hline
\end{tabular}

Figura 19 - Quadro dos parâmetros do Rapid Visco Analyser utilizados para determinação das propriedades das pastas dos amidos

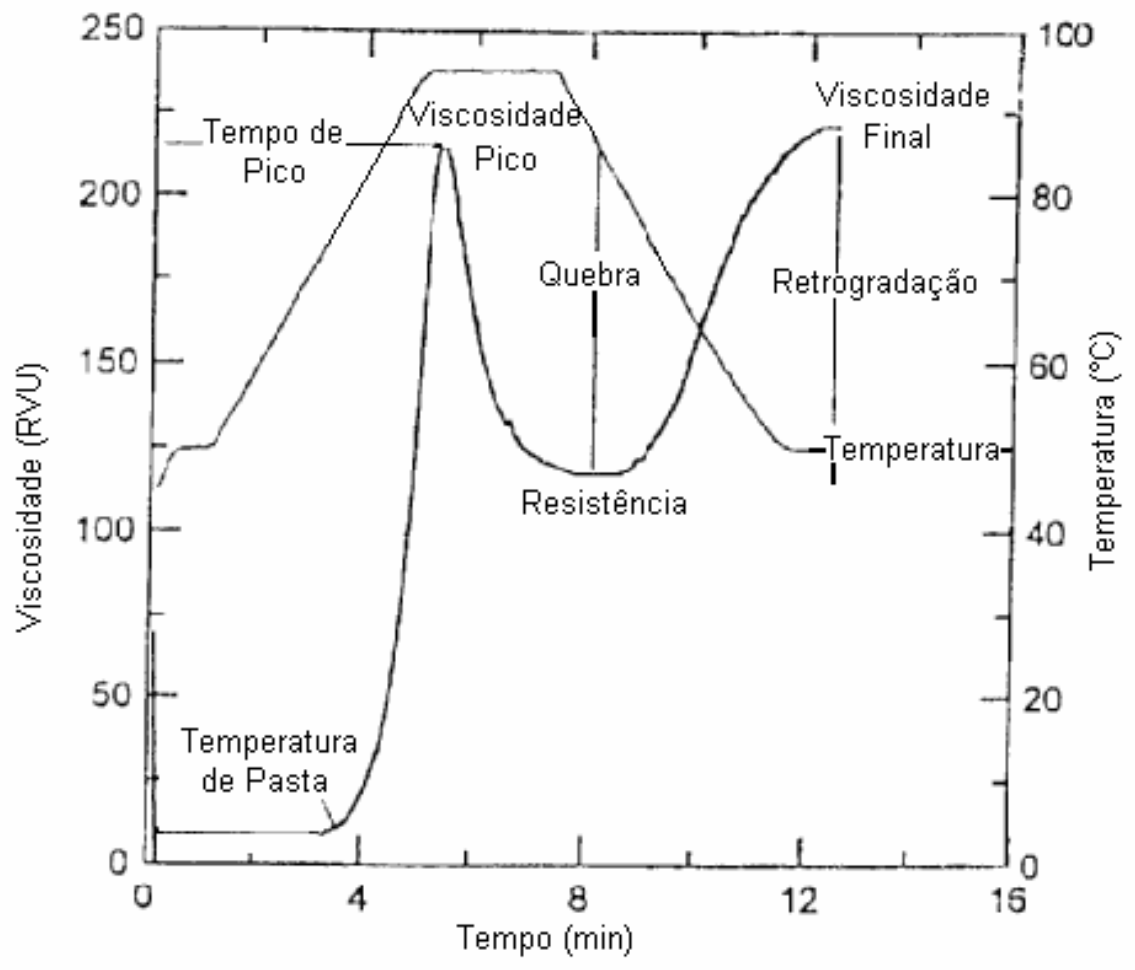

Figura 20 - Curva típica do RVA

Fonte: Thomas \& Atwell (1999)

\subsubsection{Tratamento estatístico}


Para o delineamento experimental foram utilizados 3 lotes distintos (ou 3 repetições). Os valores médios e os desvios padrões foram reportados. As análises de variância (ANOVA) e o teste de Tukey $(p<0,05)$ foram feitos usando o programa SPSS, versão 12.

Modelos considerados nesta análise

Análise de variância com um fator:

$$
Y_{i j}=\mu_{i}+\varepsilon_{i j},
$$

Onde:

- $\quad Y_{\mathrm{ij}}$ : valor da variável resposta no j-ésimo ensaio para o i-ésimo nível do fator.

- $\quad \mu_{\mathrm{i}}$ : parâmetros

- $\quad \varepsilon_{\mathrm{ij}}$ : erros associados ao modelo e são supostamente independentes com

distribuição $N\left(0, \sigma^{2}\right)$.

Este modelo é chamado modelo de média de casela. Este modelo é usado para estudos observacionais ou dados experimentais (conforme foi o caso aqui).

Análise de variância com dois fatores.

$$
Y_{i j k}=\mu_{. .}+\alpha_{i}+\beta_{j}+(\alpha \beta)_{i j}+\varepsilon_{i j k} .
$$

Onde:

- $\quad \mu .$. : constante.

- $\quad \alpha_{i}$ : constantes sujeito a restrição $\sum \alpha_{i}=0$.

- $\quad \beta \mathrm{j}$ : constantes sujeito a restrição $\sum \beta_{j}=0$.

- $\quad(\alpha \beta)_{i j}$ são constantes sujeito as restrições: $\sum_{i}(\alpha \beta)_{i j}=0$ e $\sum_{j}(\alpha \beta)_{i j}=0$ (aqui está representando a interação entre os fatores).

- $\quad \varepsilon_{\mathrm{ijk}}$ : erros associados ao modelo e são supostos independentes com distribuição $N\left(0, \sigma^{2}\right)$.

- $\quad \mathrm{Y}_{\mathrm{ijk}}$ : variável resposta. 


\section{RESULTADOS E DISCUSSÃO}

\subsection{Características dos grânulos de amidos}

Os grânulos de amido extraídos de mandioquinha-salsa, batata-doce e gengibre podem ser visualizados pelas fotomicrografias da Figura 21.

Os grânulos de amido de mandioquinha-salsa apresentaram as formas redonda, truncada e irregular. Já Bermudez (1997) ${ }^{3}$, citado por Franco et al. (2001), encontrou para o grânulo deste amido as formas elipsóide e truncada.

O amido de batata-doce apresentou grânulos com formato arredondado e poligonal. Estes formatos foram também observados por Garcia \& Leonel (2002) e Hoover (2001). Este último autor citou também a forma ovalada.

As formas observadas para os grânulos de amido de gengibre foram a oval e a irregular, e estão de acordo com o encontrado por Cereda \& Leonel (2002) para esta mesma fonte amilácea.

\footnotetext{
${ }^{3}$ Bermudez, op. cit. P.11.
} 


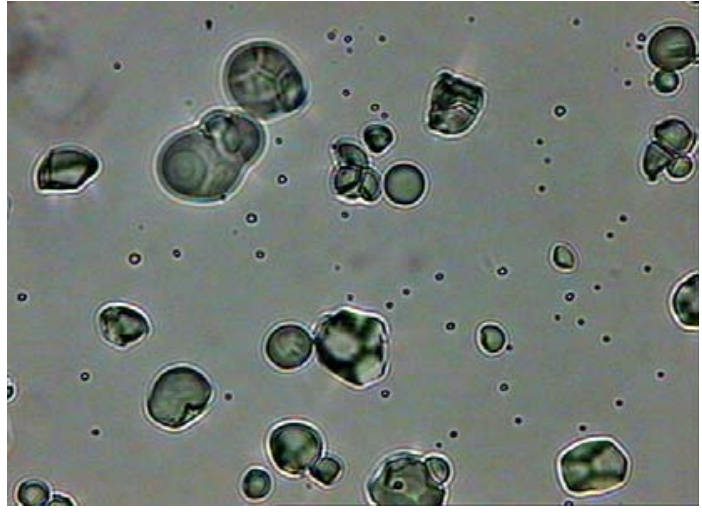

a) Mandioquinha-salsa

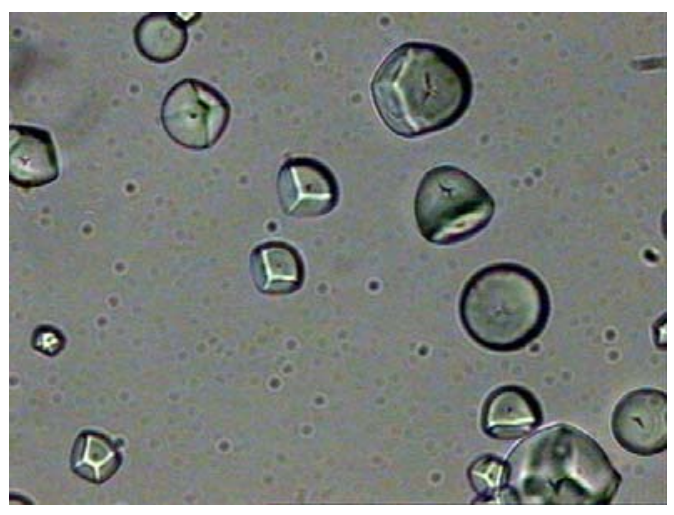

b) Batata-doce

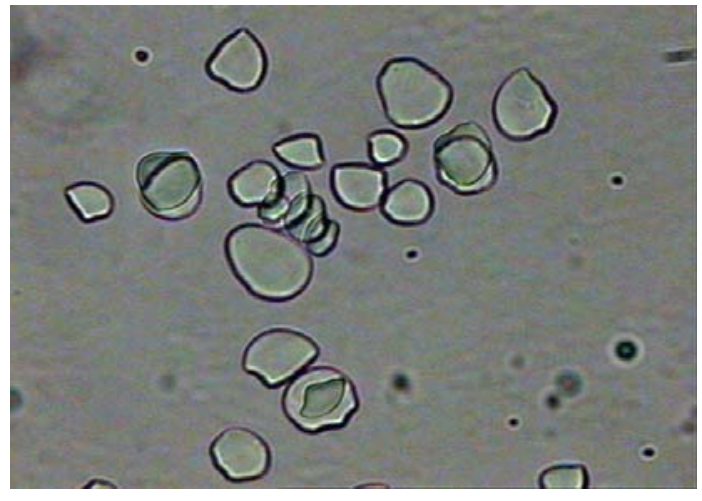

c) Gengibre

Figura 21- Imagem dos amidos de mandioquinha-salsa (a), batata-doce (b) e gengibre (c) em microscópio óptico

O tamanho dos grânulos e sua distribuição estão entre os fatores que influenciam as propriedades funcionais dos amidos, além disto, é um importante parâmetro para se definir etapas do processo de extração deste polissacarídeo.

Considerando a irregularidade encontrada para os formatos dos grânulos de amido dessas tuberosas, na mensuração dos mesmos foram considerados os diâmetros mínimo e máximo e ainda a área superficial de cada um.

As médias de tamanho dos grânulos de amido das diversas tuberosas são apresentadas na Tabela 1. 
Tabela 1. Tamanho médio dos grânulos de amido extraído das tuberosas

\begin{tabular}{|c|c|c|c|}
\hline \multirow[t]{2}{*}{ Amidos } & \multicolumn{2}{|c|}{ Diâmetro } & \multirow{2}{*}{$\begin{array}{l}\text { Área superficial } \\
\text { específica }\left(\mu \mathrm{m}^{2}\right)\end{array}$} \\
\hline & menor $(\mu \mathrm{m})$ & maior $(\mu \mathrm{m})$ & \\
\hline Mandioquinha-salsa & $12,4 \pm 1,08^{a}$ & $17,3 \pm 4,51^{a}$ & $159,0 \pm 29,70^{a}$ \\
\hline Batata-doce & $20,3 \pm 1,02^{b}$ & $26,2 \pm 0,57^{b}$ & $392,1 \pm 42,93^{c}$ \\
\hline Gengibre & $17,6 \pm 1,27^{b}$ & $23,2 \pm 1,89^{b}$ & $287,0 \pm 41,70^{b}$ \\
\hline
\end{tabular}

Nota: médias com letras diferentes dentro da mesma coluna diferiram significativamente entre si em nível de $5 \%$ pelo teste de Tukey

Os tamanhos médios dos grânulos de amido da mandioquinha-salsa e batatadoce no presente trabalho se mostraram superiores aos encontrados por Bermudez $(1997)^{1}$, citado por Franco et al. (2001) para estes amidos, que foram 8 e 10 $\mu \mathrm{m}$, respectivamente para diâmetro médio mínimo e máximo da mandioquinha-salsa e 10 e $15 \mu \mathrm{m}$ para a batata-doce. Já o amido de gengibre apresentou grânulos de tamanho inferior ao encontrado por Reyes et al. (1982), que foram diâmetros médios mínimo e máximo na faixa de 21,1 e 24,4 $\mu \mathrm{m}$, respectivamente. As diferenças no tamanho médio dos grânulos podem ser resultantes do uso de plantas de diferentes variedades, idades ou épocas de colheitas, ou ainda, podem decorrer de metodologia de mensuração do tamanho.

Dentre as estudadas, as plantas de mandioquinha-salsa apresentaram grânulos de amido com tamanho menor e as de gengibre e de batata doce apresentaram grânulos com tamanho maior, que não diferiram significativamente entre si quanto a diâmetro médio maior e menor. As áreas superficiais médias dos grânulos de amido das tuberosas estudadas, entretanto, se mostraram distintas entre si, ou seja, por ordem decrescente: batata-doce > gengibre > mandioquinha-salsa.

A avaliação do tamanho dos grânulos de amido foi também efetuada sob a forma de percentuais de distribuição de diâmetros por classes de tamanho. Os histogramas são apresentados na Figura 22. 
A amplitude de variação de tamanho dos grânulos de amido extraído da

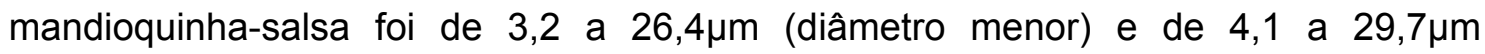
(diâmetro maior). Pelo histograma da Figura.., a classe de diâmetro menor que varia de 11 a $15 \mu \mathrm{m}$ concentra o maior percentual de grânulos, bem destacada das demais faixas. Esse amido apresentou a menor amplitude de variação de diâmetro maior dentre as espécies estudadas, tendo a maioria dos grânulos com diâmetro maior na faixa de 16 a $20 \mu \mathrm{m}$.

A amplitude de variação de tamanho dos grânulos de amido extraídos da

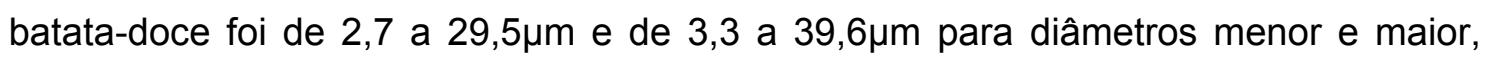
respectivamente. Esses valores estão bem próximos à faixa de variação de tamanho citada por Hoover (2001) para esta fonte de amido, que foi de de 2 a $42 \mu \mathrm{m}$. Este amido apresentou grânulos com tamanho superior aos demais, com percentual mais elevado de grânulos com diâmetro menor na faixa de 16 a $20 \mu \mathrm{m}$ e com diâmetro maior na faixa de 26 a $30 \mu \mathrm{m}$.

No amido extraído de gengibre foram encontrados grânulos variando de 3,7 a $33,4 \mu \mathrm{m}$ quanto ao diâmetro menor e de 4,1 a 37,9um quanto ao diâmetro maior. A amplitude de variação dos diâmetros menores foi a maior dentre as espécies estudadas, estando a maior concentração desses grânulos na faixa de 16 a $20 \mu \mathrm{m}$. O maior percentual de grânulos apresentou diâmetro maior na faixa de 21 a $25 \mu \mathrm{m}$. 


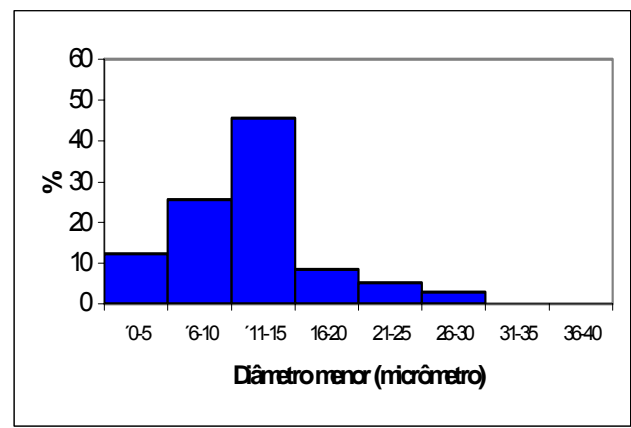

(A)

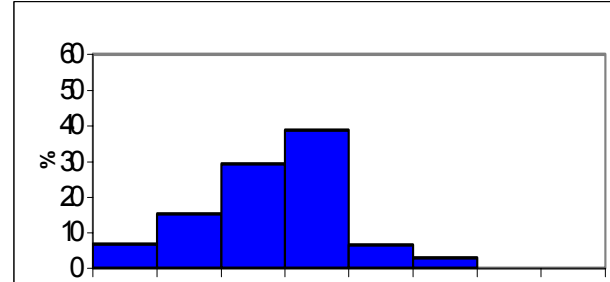

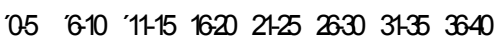

Dânthonenar (miaûâturo)

(B)

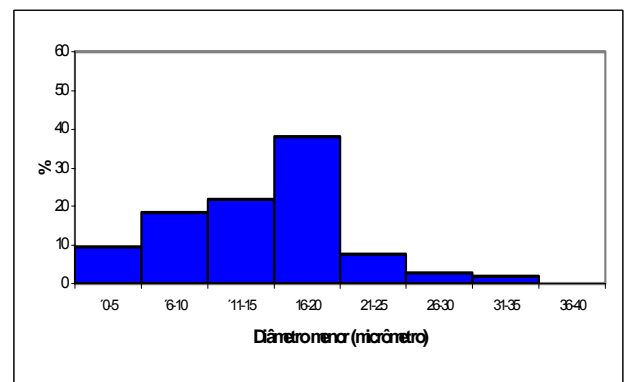

(C)

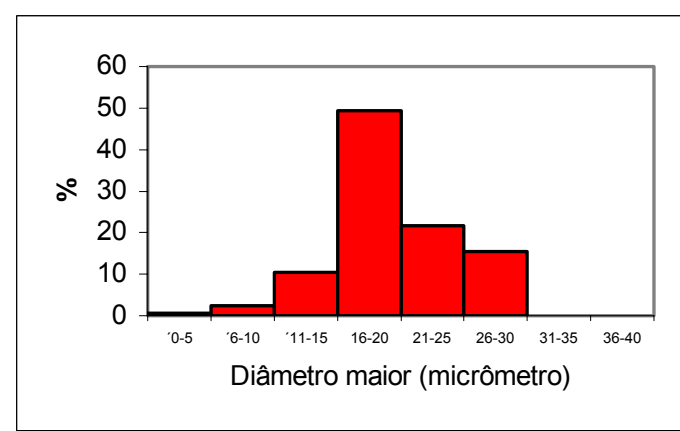

(D)

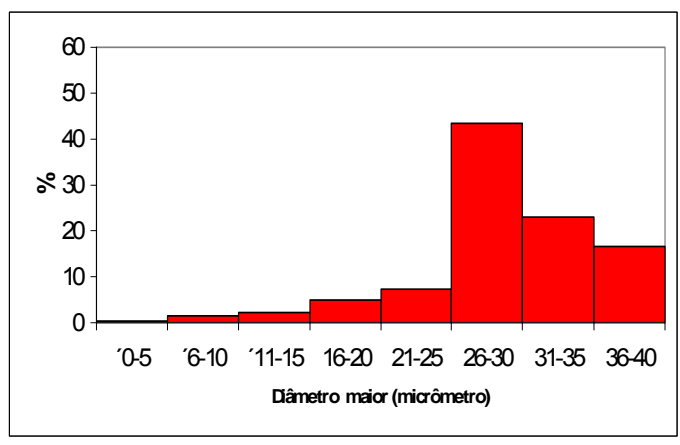

(E)

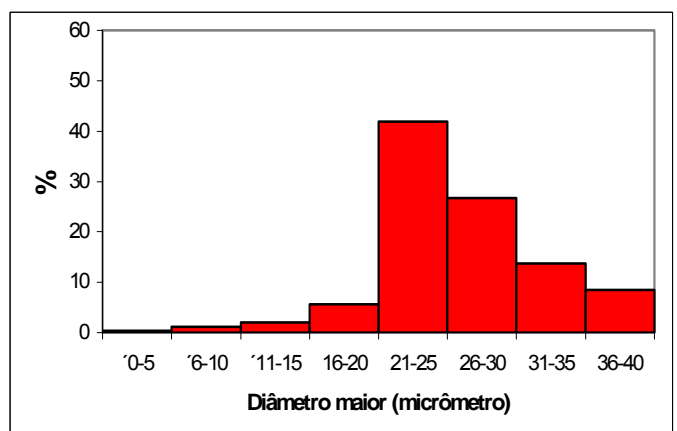

(F)

Figura 22 - Histogramas dos diâmetros mínimo e máximo dos amidos da mandioquinha-salsa ( $A$ e $B$ ), da batata-doce ( $C$ e $D)$ e gengibre ( $E$ e F) 


\subsection{Composição dos grânulos de amidos}

Os amidos isolados de mandioquinha-salsa, batata-doce e gengibre apresentaram valores de $\mathrm{pH} 7,5 \pm 0,1,7,4 \pm 0,1$ e 7,0 4 0,3, respectivamente. Esta variação decorre da composição e $\mathrm{pH}$ natural de cada matéria-prima, considerando também que não foram utilizados produtos químicos para o processo de extração e purificação dos mesmos e que este se deu em um curto intervalo de tempo. Os teores de umidade apresentados pelos amidos extraídos foram de 12,4 \% $\pm 2,3$ para o amido de mandioquinha-salsa, de 9,9\% \pm 0,9 para o amido de batata-doce e de $10,1 \%$ $\pm 0,5$ para o amido de gengibre. Todos os valores ficaram abaixo de $14 \%$, teor máximo permitido pela legislação brasileira (Brasil, 1987). O amido presente nos vegetais é extraído por processos que geralmente permitem que o mesmo carregue consigo parte dos componentes presentes nos tecidos parenquimáticos como proteínas, lipídeos e cinzas. Muito embora presentes em pequenas quantidades no amido estas substâncias acompanhantes podem interferir nas propriedades físico-químicas e funcionais dos mesmos (Cereda \& Leonel, 2002).

Tabela 2. Teores de cinzas (\% base seca) dos amidos das tuberosas

\begin{tabular}{llcc}
\hline \multicolumn{1}{c}{ Amidos } & Cinzas (\%) & \multicolumn{2}{c}{$\begin{array}{c}\text { DADOS DA LITERATURA } \\
\text { Cinzas (\%) }\end{array}$} \\
& & \multicolumn{2}{c}{ Amidos } \\
& & 0,18 & Peferencias \\
\hline Mandioquinha-salsa & $0,21 \pm 0,05^{\mathrm{a}}$ & 0,21 & Peroni (2003) \\
Batata-doce & $0,30 \pm 0,02^{\mathrm{a}}$ & 0,15 & Reyes et al. (1982), \\
Gengibre & $0,33 \pm 0,11^{\mathrm{a}}$ & 0,50 & Peroni (2003) \\
\hline
\end{tabular}

Nota: médias com letras iguais dentro da mesma coluna não diferiram significativamente entre si em nível de $5 \%$ pelo teste de Tukey 
Os teores de componentes menores nos amidos isolados das tuberosas em estudo foram reportados na base seca e são apresentados nas Tabelas 2 a 6 .

Os teores de cinzas presentes nos amidos dessas tuberosas são apresentados na Tabela 2. Os amidos de mandioquinha-salsa e gengibre mostraram teores próximos aos encontrados na literatura. Já o amido de batata-doce apresentou teor superior ao que foi encontrado por Peroni (2003).

Tabela 3. Teores de proteína bruta dos amidos das tuberosas

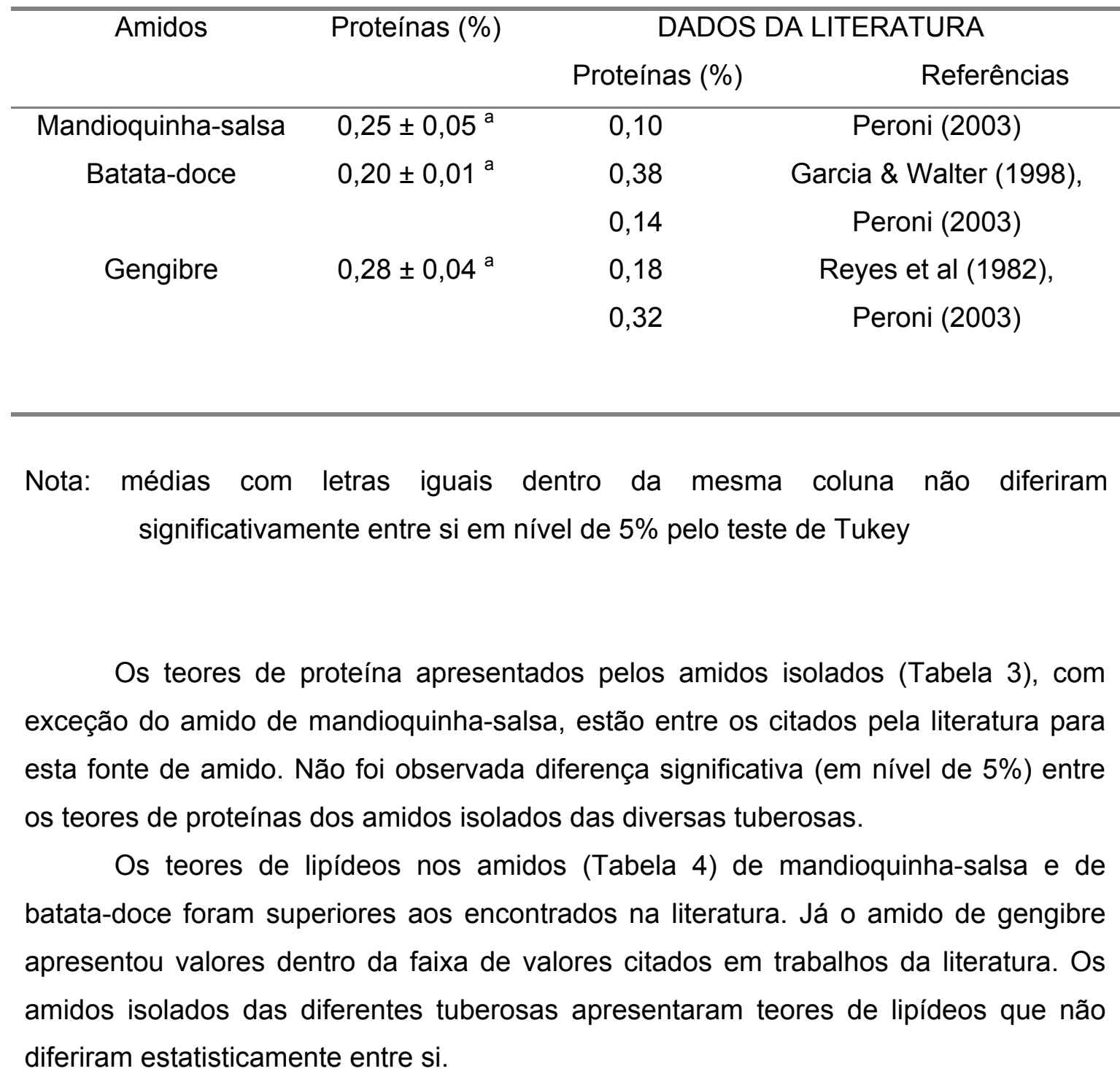


Tabela 4. Teores de lipídeos (\% base seca) nos amidos das tuberosas amiláceas

\begin{tabular}{|c|c|c|c|}
\hline \multirow[t]{2}{*}{ Amidos } & \multirow[t]{2}{*}{ Lipídeos (\%) } & \multicolumn{2}{|c|}{ DADOS DA LITERATURA } \\
\hline & & Lipídeos (\%) & Referências \\
\hline Mandioquinha-salsa & $0,19 \pm 0,05^{a}$ & 0,13 & Peroni (2003) \\
\hline \multirow[t]{2}{*}{ Batata-doce } & $0,21 \pm 0,09^{a}$ & $0,06-, 060$ & Tian et al. (1991), \\
\hline & & 0,14 & Peroni (2003) \\
\hline \multirow[t]{2}{*}{ Gengibre } & $0,17 \pm 0,05^{a}$ & 0,10 & Reyes et al. (1982), \\
\hline & & 0,24 & Peroni (2003) \\
\hline
\end{tabular}

Nota: médias com letras iguais dentro da mesma coluna não diferiram significativamente entre si em nível de $5 \%$ pelo teste de Tukey

Os teores de lipídeos presentes nessas fontes de amidos podem ser considerados baixos se comparados com os teores encontrados em amidos extraídos de cereais como o milho e o arroz, que apresentam 0,6 e 0,5\%, respectivamente. Os amidos estudados podem, portanto, ser considerados mais neutros e menos sujeitos a complexações que os amidos de cereais.

$\mathrm{Na}$ avaliação da composição química dos amidos estudados as frações cinzas, lipídeos e proteínas, juntas, somaram $0,65 \%, 0,70 \%$ e 0,79\%, respectivamente para os amidos de mandioquinha-salsa, batata-doce e gengibre. Todas as somatórias resultaram em valores inferiores a $1 \%$. Os processos de extração e purificação do amido utilizados no presente experimento para estas tuberosas, em nível de laboratório foram, portanto, eficientes.

Segundo Tester et al. (2004) os amidos normalmente apresentam pequenas quantidades de minerais (cálcio, magnésio, fósforo, potássio e sódio) dentre os quais apenas o fósforo apresenta significância funcional. O fósforo pode ser encontrado nos grânulos de amido nas formas de monoester fosfato, fosfolipídeos e fosfato inorgânico. Geralmente os amidos apresentam pequenos teores de fósforo, com exceção do amido de batata, que praticamente não apresenta lipídeos e o teor de monoester fosfato pode exceder a $0,1 \%$. Kerr (1950), afirma que a presença de moléculas 
esterificadas com fósforo forma uma barreira impedindo que as enzimas atinjam os sítios de ação.

O fósforo pode contribuir, quando presente em quantidades mais elevadas, para uma maior viscosidade e claridade da pasta, aumento da capacidade de ligação com água e poder de inchamento (Lim et al., 1994).

Os teores de fósforo encontrados nos amidos das tuberosas estudadas (Tabela 5) foram superiores aos citados pela literatura, o que provavelmente decorre da variedade e idade da planta ou ainda, da metodologia utilizada na determinação deste composto.

Tabela 5. Teores de fósforo nos amidos das tuberosas

\begin{tabular}{|c|c|c|c|}
\hline \multirow[t]{2}{*}{ Amidos } & \multirow[t]{2}{*}{ Fósforo (\%) } & \multicolumn{2}{|c|}{ DADOS DA LITERATURA Fósforo (\%) } \\
\hline & & \multicolumn{2}{|c|}{ Referências } \\
\hline Mandioquinha-salsa & $0,032 \pm 0,003^{a}$ & 0,015 & Peroni(2003) \\
\hline \multirow[t]{2}{*}{ Batata-doce } & $0,027 \pm 0,003^{b}$ & 0,012 & Lim et al.(1994), \\
\hline & & 0,014 & Peroni (2003) \\
\hline Gengibre & $0,022 \pm 0,001^{c}$ & 0,007 & Peroni (2003) \\
\hline
\end{tabular}

Nota: médias com letras diferentes dentro da mesma coluna diferiram significativamente entre si em nível de $5 \%$ pelo teste de Tukey

A análise de variância e o teste de Tukey indicaram que há diferença significativa entre os valores encontrados para as diferentes tuberosas. O teor de fósforo se mostrou crescente na ordem: amido de mandioquinha-salsa > batata-doce > gengibre. Os valores de fósforo no amido destas tuberosas foram, contudo, inferiores aos encontrados no amido da batata inglesa, que é de 0,09\% (Franco et al., 2001).

As macromoléculas presentes nos amidos são a amilose e a amilopectina. A taxa de amilose/amilopectina pode alterar propriedades funcionais dos amidos, dentre as quais, a gelatinização, retrogradação, empastamento, inchamento e hidrólise 
enzimática (Gallant et al., 1982). Os teores de amilose dos amidos das diferentes fontes botânicas estudadas são apresentados na Tabela 6 .

Tabela 6. Teores de amilose aparente nos amidos das tuberosas

\begin{tabular}{lccc}
\hline \multicolumn{1}{c}{ Amidos } & Teor de & \multicolumn{2}{c}{ DADOS DA LITERATURA } \\
& $\begin{array}{c}\text { amilose } \\
(\%)\end{array}$ & Teor de amilose (\%) & Referências \\
& $17,2 \pm 1,5^{\text {a }}$ & 20,0 & Gonzáles \& Carrasco (2001), \\
Mandioquinha- & 15,3 & Hoover (2001), \\
Salsa & 21,3 & Peroni (2003) \\
Batata-Doce & $22,2 \pm 1,3$ & $19,7-23,1$ & Noda et al. (1992b), \\
& b & 22,8 & McPherson \& Jane (1999), \\
& & $16,0-27,0$ & Hoover (2001), \\
& & 19,1 & Collado \& Corke (1999), \\
Gengibre & 25,6 & Peroni (2003) \\
& & 22,2 & Reyes et al. (1982), \\
& & 28,2 & Peroni (2003) \\
\hline
\end{tabular}

Nota: médias com letras diferentes dentro da mesma coluna diferiram significativamente entre si em nível de $5 \%$ pelo teste de Tukey

Os teores de amilose aparente dos amidos estão dentro das faixas citadas pela literatura. Observa-se grande variabilidade nestes resultados da literatura, que decorre do uso de diferentes metodologias de determinação, variedades ou idades das plantas utilizadas nos experimentos.

O teor de amilose aparente presente no amido de mandioquinha-salsa foi significativamente menor que os teores presentes nos amidos de batata-doce e gengibre, que não diferiram entre si. 


\subsection{Digestibilidade enzimática dos amidos naturais e tratados termicamente sob baixa umidade}

\subsubsection{Percentual de hidrólise dos amidos}

A porcentagem de hidrólise e a cinética da hidrólise enzimática dos amidos granulares foram parâmetros utilizados para se avaliar o efeito do tratamento com calor e baixa umidade sobre os amidos das tuberosas em estudo. A suscetibilidade enzimática dos amidos das diferentes tuberosas, natural e tratados com calor sob baixa umidade, após 24 horas de digestão com alfa-amilase bacteriana e amiloglucosidase fúngica pode ser visualizada pela Tabela 7.

Pela Tabela 7 foram evidenciadas diferenças significativas entre os amidos das diversas tuberosas estudadas quanto à suscetibilidade enzimática, tanto entre amidos naturais, como entre amidos tratados por TCBU, e também antes e após o processo TCBU.

No caso dos amidos naturais foi observada diferença significativa entre as fontes botânicas avaliadas. O amido de batata-doce apresenta elevada suscetibilidade enzimática, enquanto que o de gengibre a maior resistência às enzimas estudadas. A mesma diferenciação observada para amidos naturais se manteve nos amidos tratados com TCBU, muito embora, em grandezas superiores. Este tratamento promoveu aumentos nos percentuais de hidrólise dos amidos quando comparados com seus respectivos naturais. $\mathrm{O}$ amido de mandioquinha-salsa apresentou o aumento mais expressivo (41\%) no percentual de hidrólise com o tratamento de calor e baixa umidade, o de gengibre apresentou aumento intermediário (28\%) e o de batata-doce o menor $(5 \%)$, talvez porque este último já apresente naturalmente uma elevada suscetibilidade à ação dessas enzimas. 
Tabela 7. Porcentagem de hidrólise dos amidos das tuberosas, naturais e tratados com calor sob baixa umidade, após 24 horas de digestão enzimática

\begin{tabular}{lcc}
\hline AMIDOS & NATURAL $(\%)$ & TRATAMENTO TĖRMICO EM BAIXA \\
& & UMIDADE (\%) \\
\hline Mandioquinha-salsa & $38,0 \pm 3,69^{\mathrm{a}, 1}$ & $53,5 \pm 4,82^{\mathrm{A}, 2}$ \\
Batata-doce & $72,1 \pm 0,23^{\mathrm{b}, 1}$ & $75,9 \pm 0,61^{\mathrm{B}, 2}$ \\
Gengibre & $15,2 \pm 0,44^{\mathrm{c}, 1}$ & $19,5 \pm 0,55^{\mathrm{c}, 2}$ \\
\hline
\end{tabular}

- As letras a, b e c demonstram diferenças significativas entre o percentual de hidrólise dos amidos naturais das diferentes fontes botânicas em nível de $5 \%$ pelo teste de Tukey

- Os números 1 e 2 demonstram diferença significativa entre os porcentuais de hidrólise dos amidos da mesma fonte botânica, antes e após tratamento térmico sob baixa umidade, em nível de $5 \%$ pelo teste de Tukey

- As letras A, B e C demonstram diferenças significativas entre percentuais de hidrólise dos amidos das diferentes fontes botânica tratadas termicamente sob baixa umidade, em nível de $5 \%$ pelo teste de Tukey

Segundo Hoover \& Manuel (1996), o aumento da porcentagem de hidrólise nos amidos tratados com TCBU se deve a uma maior concentração de enzima dentro do grânulo, que pode ser causada pela maior facilidade de entrada das mesmas através das fissuras criadas na superfície do grânulo pelo tratamento.

Para Cone \& Wolters (1990) os amidos com maior teor de amilose são mais suscetíveis à degradação enzimática com a-amilase que os com menor teor desta macromolécula. Já Sandstead et al. (1962) afirmam que as diferenças nas suscetibilidades enzimática dos grânulos de amido não estão diretamente relacionadas ao teor de amilose e sim à estrutura dos grânulos.

Lorenz \& Kulp (1982) reportaram que o tratamento térmico sob baixa umidade provavelmente ocorra nas regiões mais amorfas dos grânulos, mais acessíveis à amilólise e um certo grau de degradação do amido se faz presente. 
Aumentos consideráveis de percentagem de hidrólise também foram encontrados por Franco (1993) para amidos cereais tratados por TCBU sob as mesmas condições do presente estudo, sendo $16 \%$ para milho normal e de $19 \%$ para milho ceroso. Este autor sugeriu que o tratamento nestas condições promove um rompimento das ligações internas dos grânulos aumentando a área acessível à hidrólise enzimática. Além disto, os dados encontrados sugeriram que o tratamento atua preferencialmente nas zonas amorfas dos grânulos de amido.

Kulp \& Lorenz (1982) encontraram para os amidos de araruta e mandioca um aumento na suscetibilidade enzimática com o TCBU $\left(100^{\circ} \mathrm{C} / 16\right.$ horas / $27 \%$ de umidade) e concluíram que esse aumento foi causado pela formação de áreas acessíveis às enzimas nos grânulos.

Gunaratne \& Hoover (2002), estudando amidos de batata, inhame, mandioca e taro tratados por TCBU $\left(100^{\circ} \mathrm{C} / 30 \%\right.$ de umidade/ 10horas), observaram aumento da suscetibilidade enzimática pela a-amilase pancreática para todos os amidos, concluindo que esse processo quebra os cristais de amido próximos à superfície do grânulo, o que facilita a entrada de enzimas para o interior dos mesmos.

\subsubsection{Cinética da digestibilidade enzimática dos amidos}

A Figura 23 mostra a quantidade de açúcares redutores (glicose) produzida durante a digestão do amido granular e do amido tratado com calor sob baixo teor de umidade (TCBU) pelas enzimas alfa-amilase bacteriana e amiloglucosidase fúngica.

Para batata-doce e gengibre após 1 hora de digestão os amidos naturais produziram maiores percentuais de açúcares redutores do que os tratados com calor em baixa umidade, entretanto, ao redor do tempo de 1,7 horas ocorreu uma inversão, que se manteve até ao final do período de digestão estudado.

As curvas obtidas para todos os amidos, naturais ou tratados por TCBU, mostraram aumento expressivo da quantidade de glucose gerada nas primeiras 7 horas de hidrólise. Após esse período continuou havendo incremento, mas a uma taxa bem reduzida. 


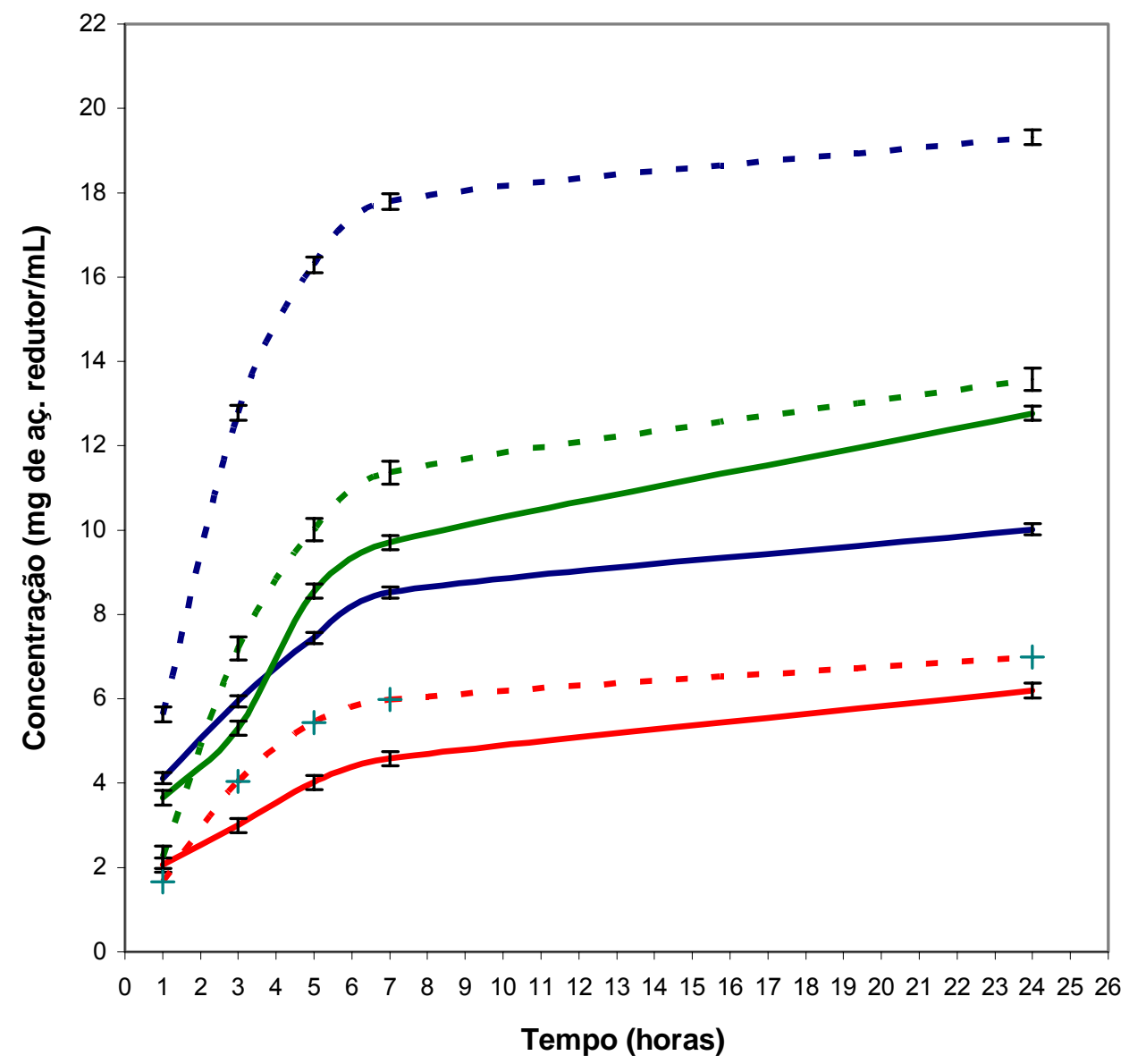

\begin{tabular}{|c|c|c|}
\hline MS NAT & $\longrightarrow$ BD NAT & $\longrightarrow$ GENG NAT \\
\hline - - MS TCBU & - $=\mathrm{BD}$ TCBU & -+ - GENG TCBU \\
\hline
\end{tabular}

Figura 23 - Teores de açúcares redutores produzidos durante a digestão enzimática dos amidos de mandioquinha-salsa, batata-doce e gengibre, tanto no estado natural (NAT) como após tratamento com calor e baixa umidade (TCBU)

Após 7 horas de digestão, os amidos de mandioquinha-salsa, batata-doce e gengibre apresentaram, respectivamente, $52 \%, 17 \%$ e $30 \%$ de aumento na quantidade de açúcar redutor produzida pela hidrólise do amido tratado com calor e baixa umidade com relação à produzida pela hidrólise do amido natural. Ao término da hidrólise estas 
diferenças caem na faixa de $48 \%, 6 \%$ e $13 \%$, respectivamente, para amidos de mandioquinha-salsa, batata-doce e gengibre.

Ao término da digestão, por ordem decrescente, a quantidade total de açúcares redutores produzida, conforme pode ser visualizado na Figura 23, foi mandioquinha TCBU > batata-doce TCBU > batata-doce natural > mandioquinha natural > gengibre TCBU > gengibre natural.

Aqui ficou evidenciado novamente o efeito expressivo do tratamento com calor em baixa umidade sobre a suscetibilidade à hidrólise enzimática do amido de mandioquinha-salsa. Já os amidos de batata-doce e gengibre foram menos afetados por este tratamento.

Hoover \& Manuel (1996) descreveram como fatores responsáveis por uma maior ação enzimática nos amidos tratados com TCBU, por ordem de importância, primeiramente o teor de amilose, a seguir o percentual de lipídeos complexados na cadeia de amilose e por último a extensão dos danos nos grânulos causados pelo processo de extração. Conforme os autores, a amilose e a presença de lipídeos complexados com as cadeias de amilose dificultam a hidrólise enzimática das mesmas. No presente estudo o teor de amilose no amido de mandioquinha foi significativamente menor $(17,2 \%)$ que os apresentados pelos amidos de batata-doce $(22,2 \%)$ e gengibre $(24,5 \%)$, os quais não apresentaram diferença significativa entre si. Os teores de lipídeos apresentados pelos grânulos das tuberosas aqui estudadas, entretanto, além de serem considerados baixos, não apresentaram diferenças significativas entre si. 


\subsection{Aspectos dos grânulos de amido vistos ao microscópio eletrônico de varredura}

Aspectos dos amidos tratados e não tratados com calor em baixa umidade e submetidos ou não à digestão enzimática, foram avaliados em microscópio eletrônico de varredura e as fotomicrografias, em dois aumentos, são apresentadas nas Figuras de 24 a 35.

As Figuras 24 e 25 mostram, respectivamente, as fotomicrografias dos grânulos de amido de mandioquinha-salsa natural e de mandioquinha-salsa após 24 horas de digestão pela alfa-amilase e amiloglucosidase. As Figuras 26 e 27 mostram, respectivamente, as fotomicrografias dos grânulos de amido de mandioquinha-salsa tratados termicamente sob baixa umidade e o amido de mandioquinha salsa tratados termicamente sob baixa umidade após 24 horas de digestão pela alfa-amilase e amiloglucosidase. 

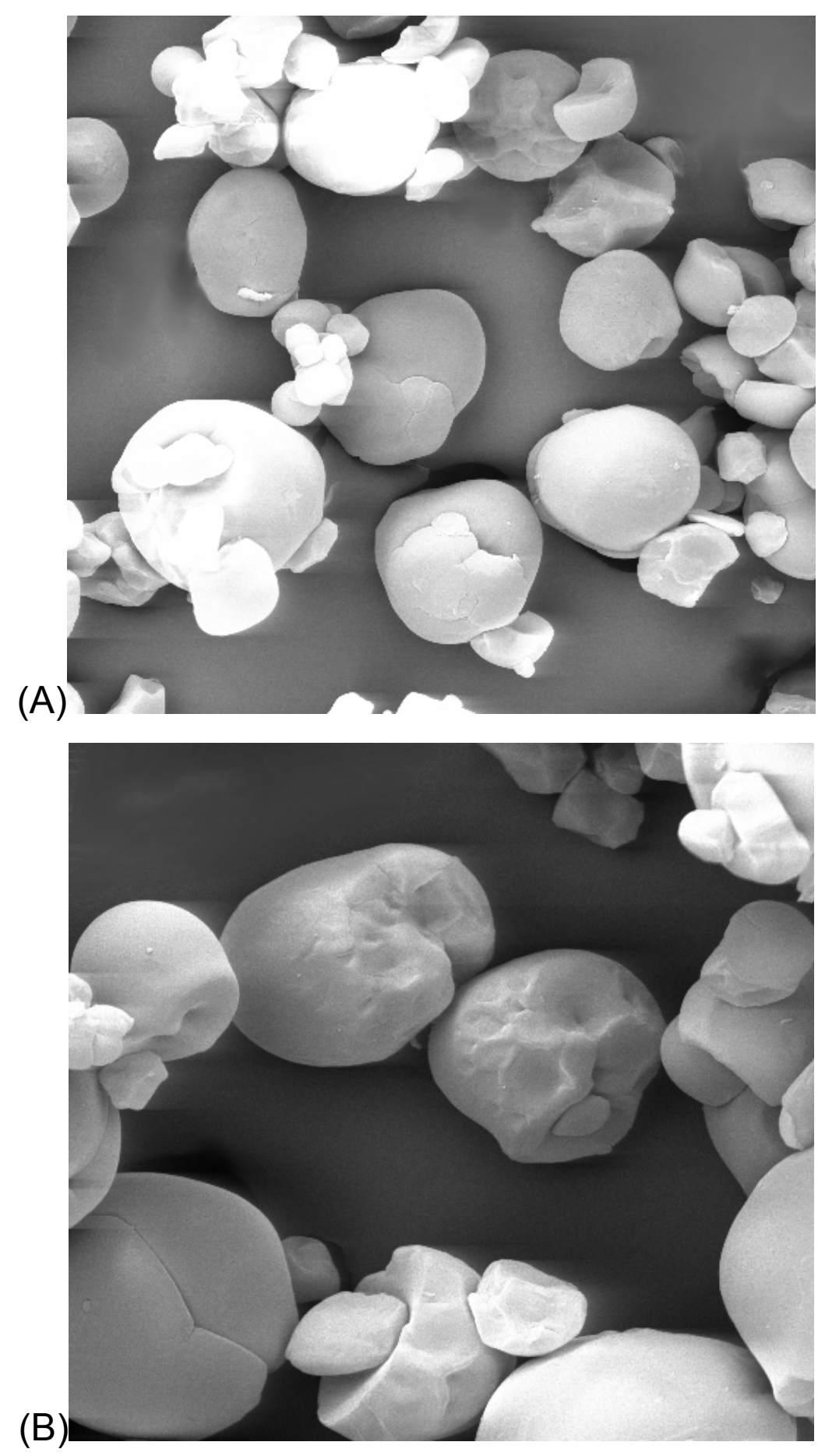

Figura 24 - Fotos dos amidos de mandioquinha-salsa em microscópio eletrônico de varredura $(20 \mathrm{kV} / 12 \mathrm{~mm})$ 


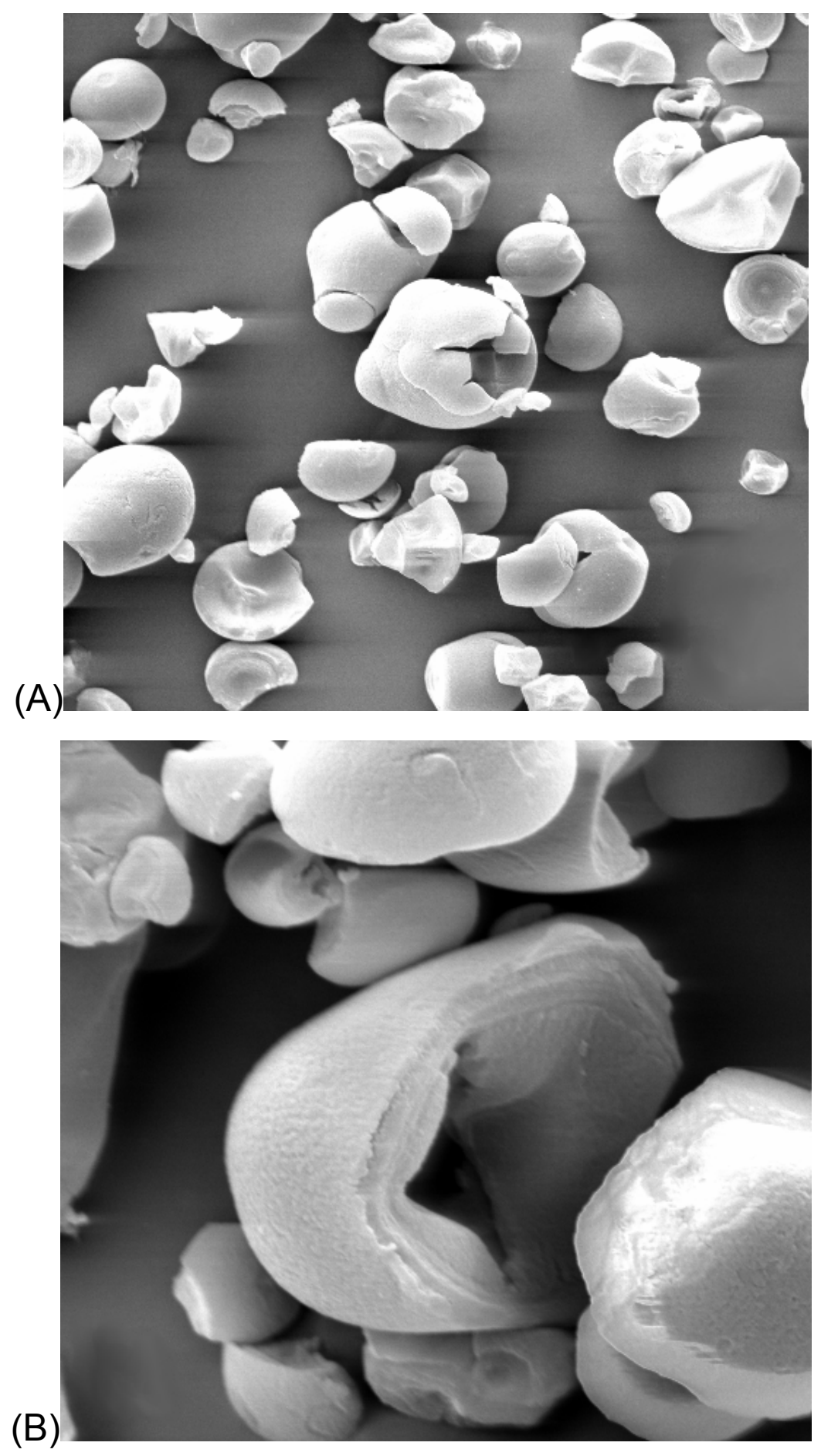

Figura 25 - Fotos dos amidos de mandioquinha-salsa após digestão enzimática em microscópio eletrônico de varredura $(20 \mathrm{kV} / 12 \mathrm{~mm})$ 


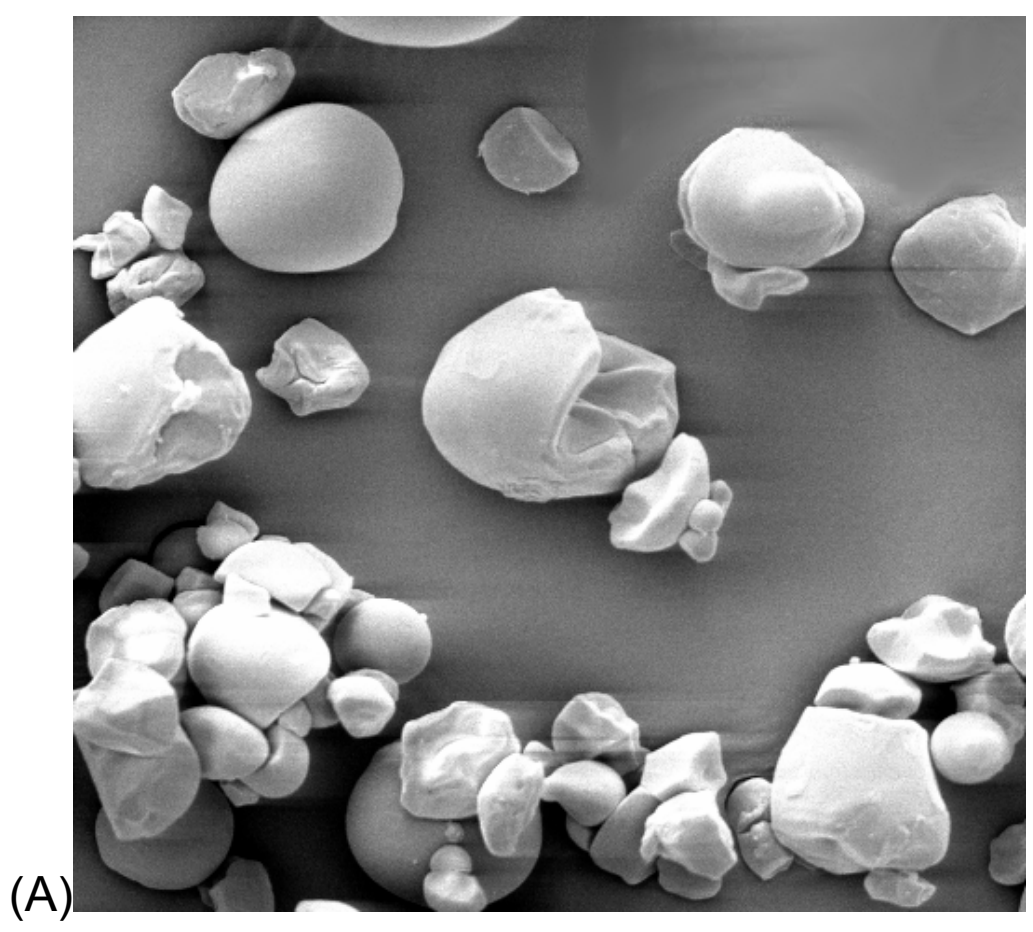

(A)

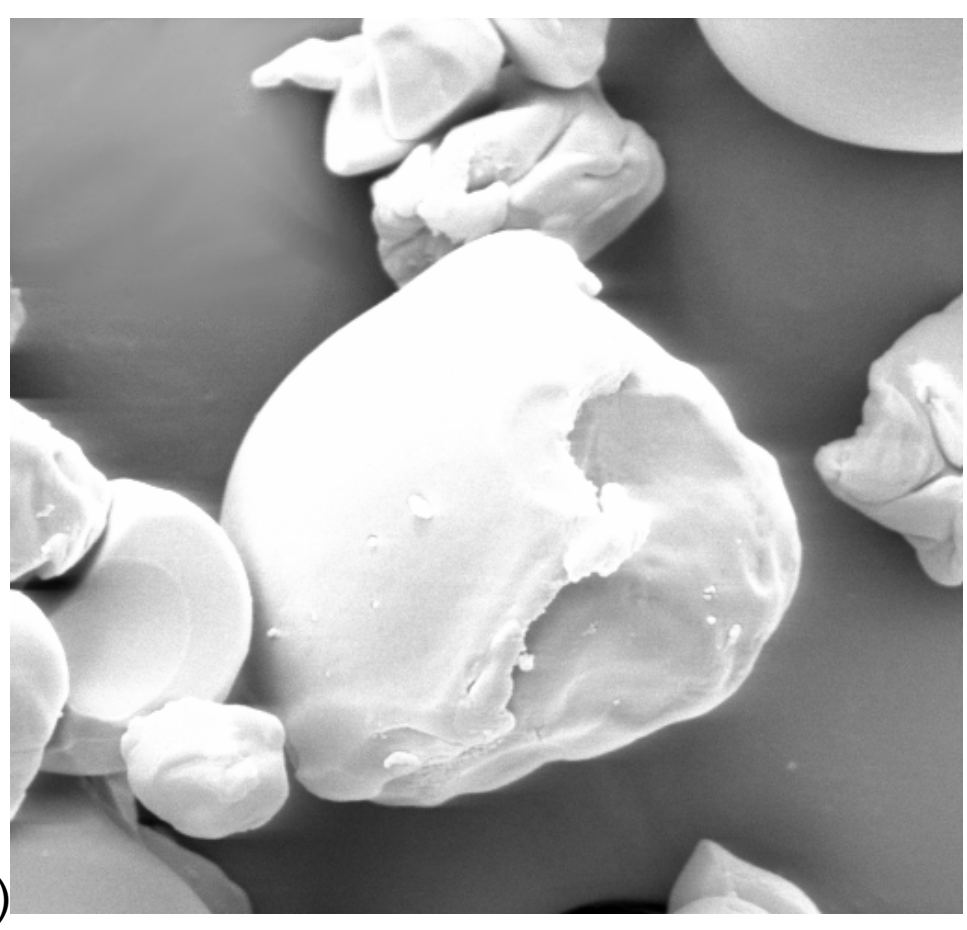

Figura 26 - Fotos dos amidos de mandioquinha-salsa tratados termicamente sob baixa umidade em microscópio eletrônico de varredura $(15 \mathrm{kV} / 12 \mathrm{~mm})$ 


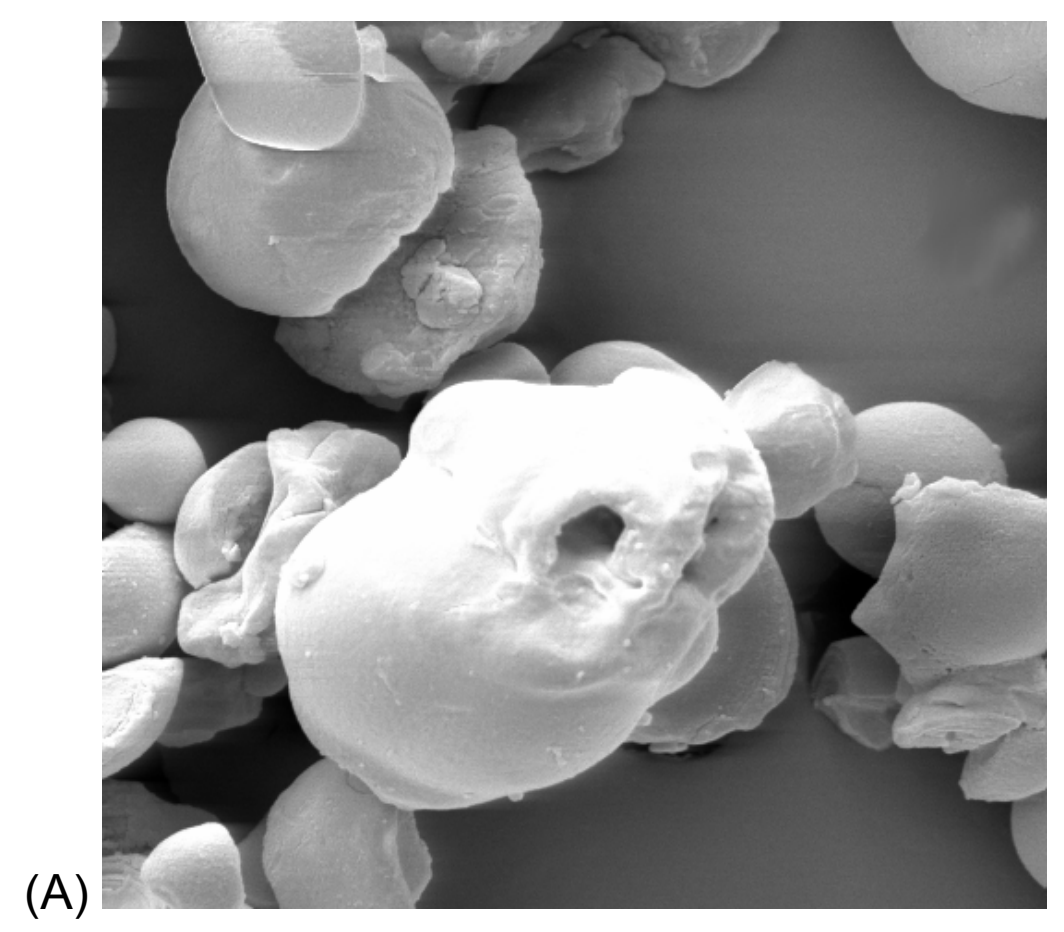

(A)

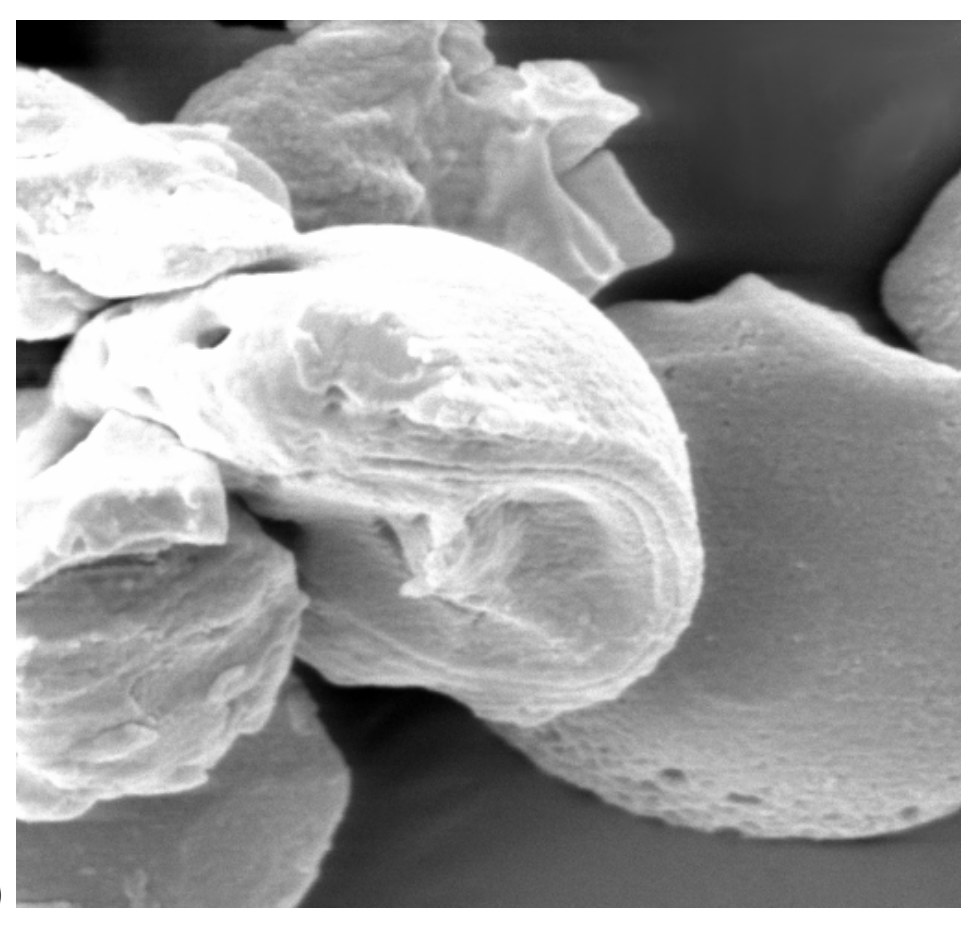

Figura 27 - Foto dos amidos de mandioquinha-salsa tratados termicamente sob baixa umidade, após digestão enzimática, em microscópio eletrônico de varredura $(15 \mathrm{kV} / 12 \mathrm{~mm})$ 
As fotos da Figura 24 mostram os amidos naturais de mandioquinha-salsa, em diferentes aumentos. $\mathrm{O}$ aspecto da superfície da maior parte desses grânulos de amido é liso, entretanto, alguns deles apresentam depressões em parte da superfície granular, conferindo aspecto ou formato irregular, truncado. $\mathrm{O}$ aspecto de truncado foi citado como formato típico do amido desta espécie em Franco et al. (2002).

As fotos da Figura 25 apresentam os amidos naturais após a digestão enzimática com a presença de alguns grânulos com pequenos orifícios na superfície. No destaque da foto $25(B)$ podem ser visualizadas as camadas concêntricas que estruturam os grânulos, evidenciando ataque enzimático mais intenso e também grânulos com desgaste superficial proporcionando aspecto mais poroso aos mesmos.

As fotos da Figura 26 mostram os grânulos de amido de mandioquinha-salsa tratados com calor e baixa umidade, que apresentaram grânulos similares aos amidos naturais. Alguns grânulos, entretanto, apresentam imperfeições, não ficando claro se estas seriam resultantes de danos pelo processo extrativo ou pelo tratamento térmico. As fotos da Figura 27 mostram os amidos tratados com calor e baixa umidade após a digestão enzimática, mostrando hidrólise mais intensa do amido, com muitos grânulos de aparência superficial porosa e outros mostrando as camadas concêntricas de sua estrutura. Possivelmente a irregularidade superficial desses grânulos, com depressões permita maior acesso às enzimas.

As Figuras 28 e 29 mostram, respectivamente, as fotomicrografias dos grânulos de amido de batata-doce natural e de batata-doce após 24 horas de digestão pela alfaamilase e amiloglucosidase. As Figuras 30 e 31 mostram, respectivamente, as fotomicrografias dos grânulos de amido de batata-doce tratados termicamente sob baixa umidade e o amido de batata-doce tratado termicamente sob baixa umidade após 24 horas de digestão pela alfa-amilase e amiloglucosidase. 

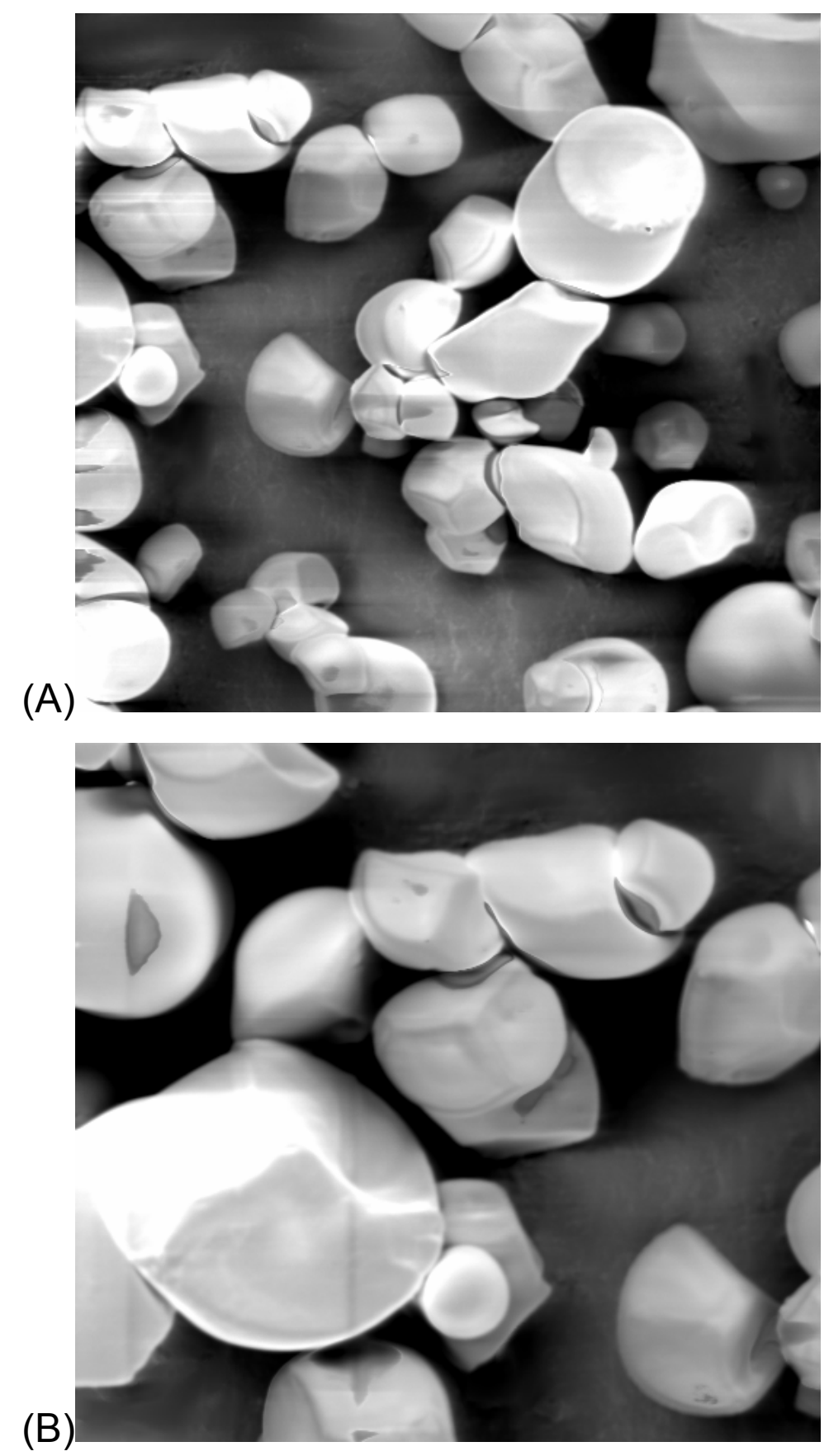

Figura 28 - Fotos dos amidos de batata-doce em microscópio eletrônico de varredura $(10 \mathrm{kV} / 12 \mathrm{~mm})$ 


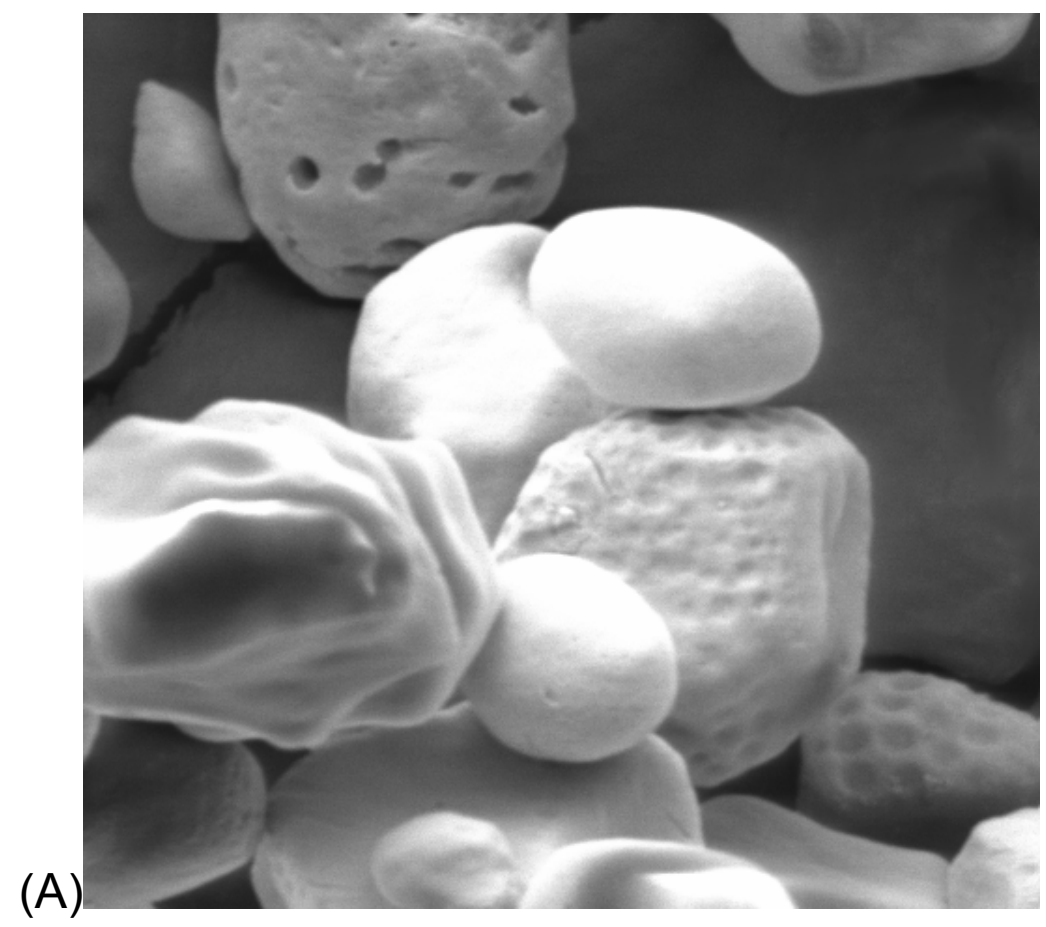

(A)

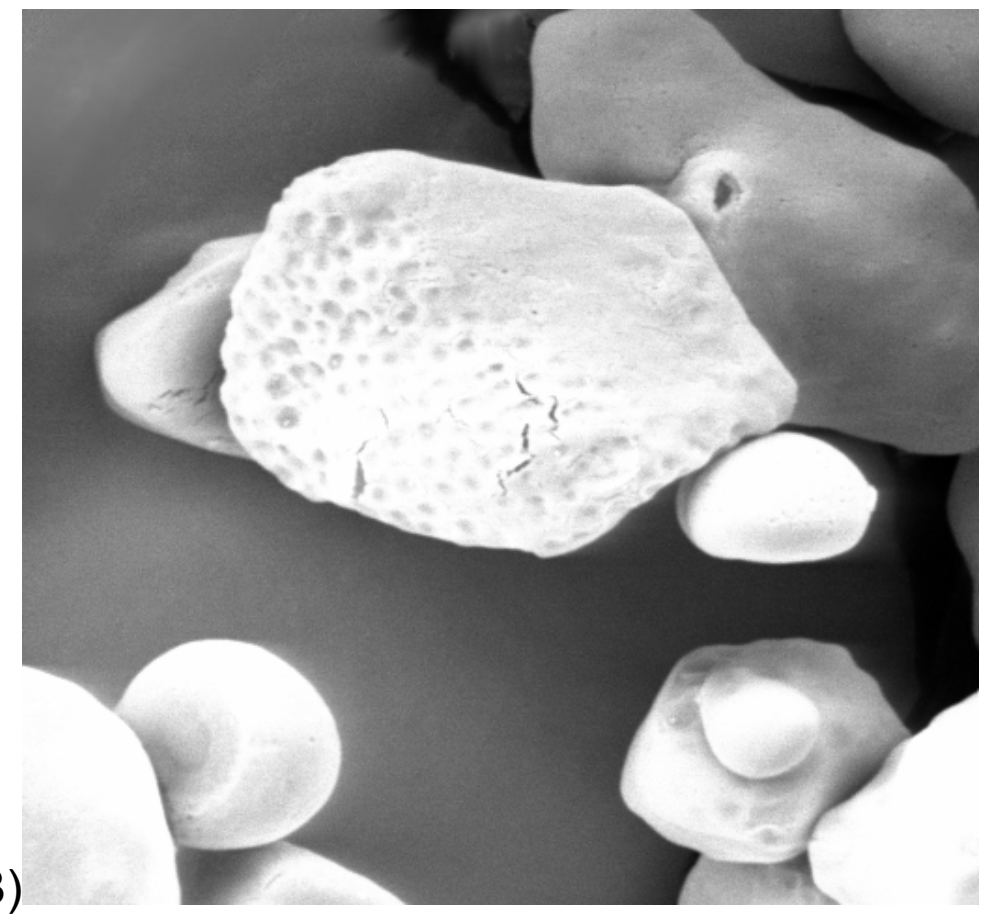

Figura 29 - Fotos dos amidos de batata-doce após digestão enzimática, em microscópio eletrônico de varredura $(15 \mathrm{kV} / 17 \mathrm{~mm})$ 

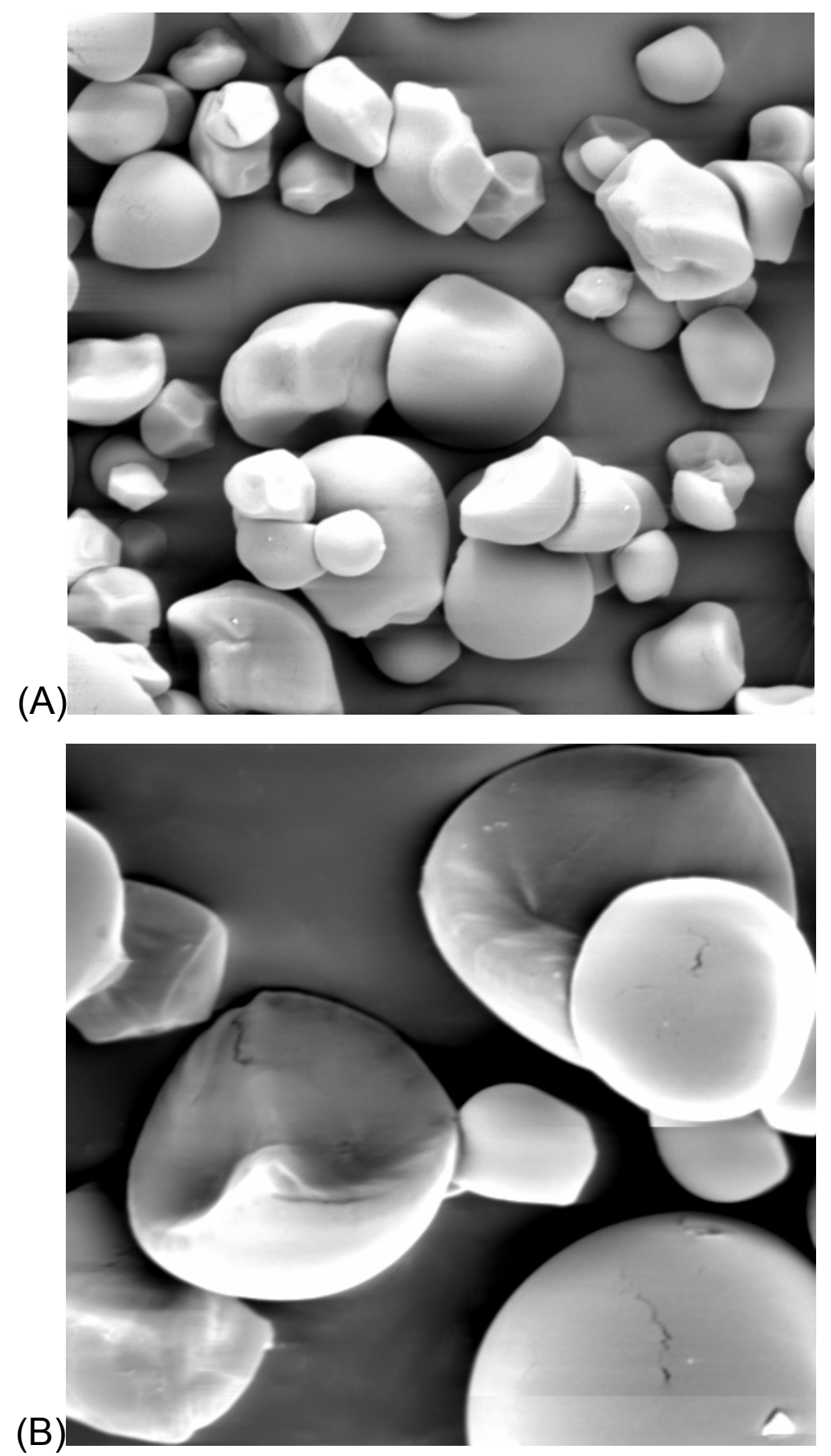

Figura 30 - Fotos dos amidos de batata-doce tratados termicamente sob baixa umidade, em microscópio eletrônico de varredura (20kV/12mm) 


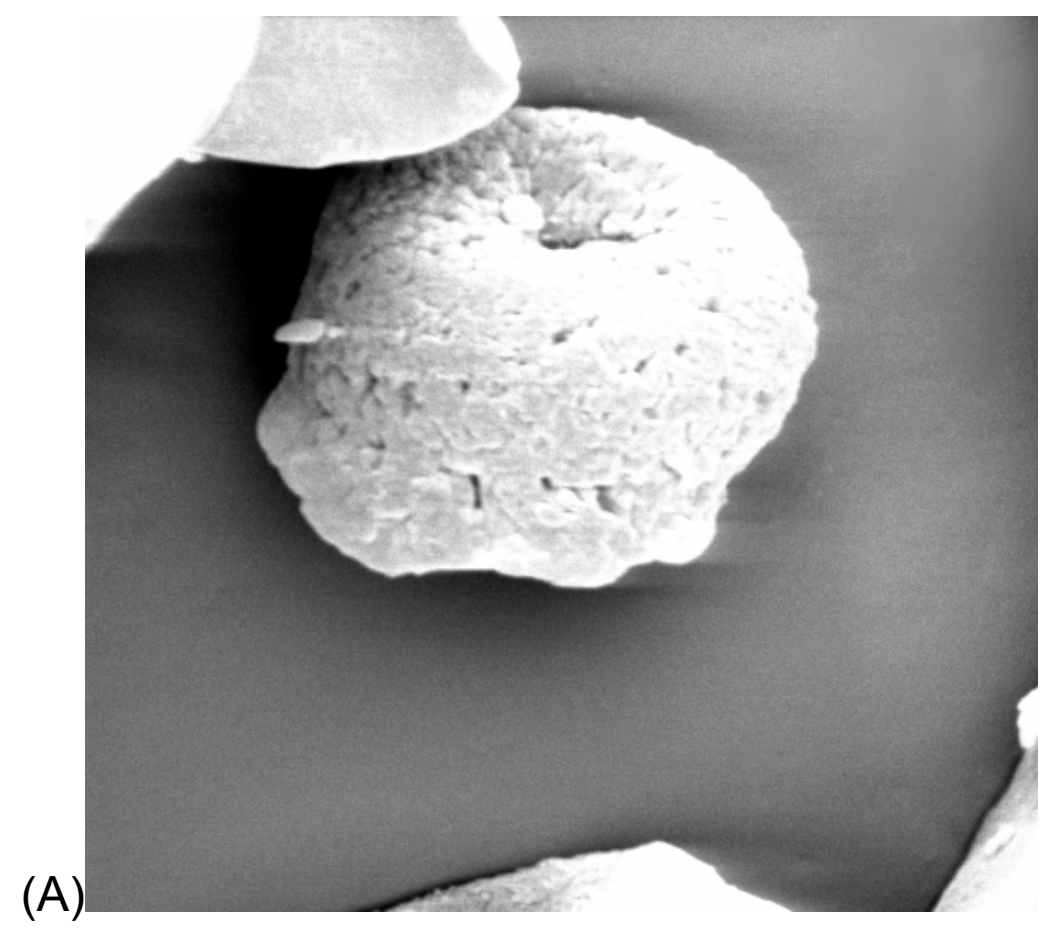

(A)

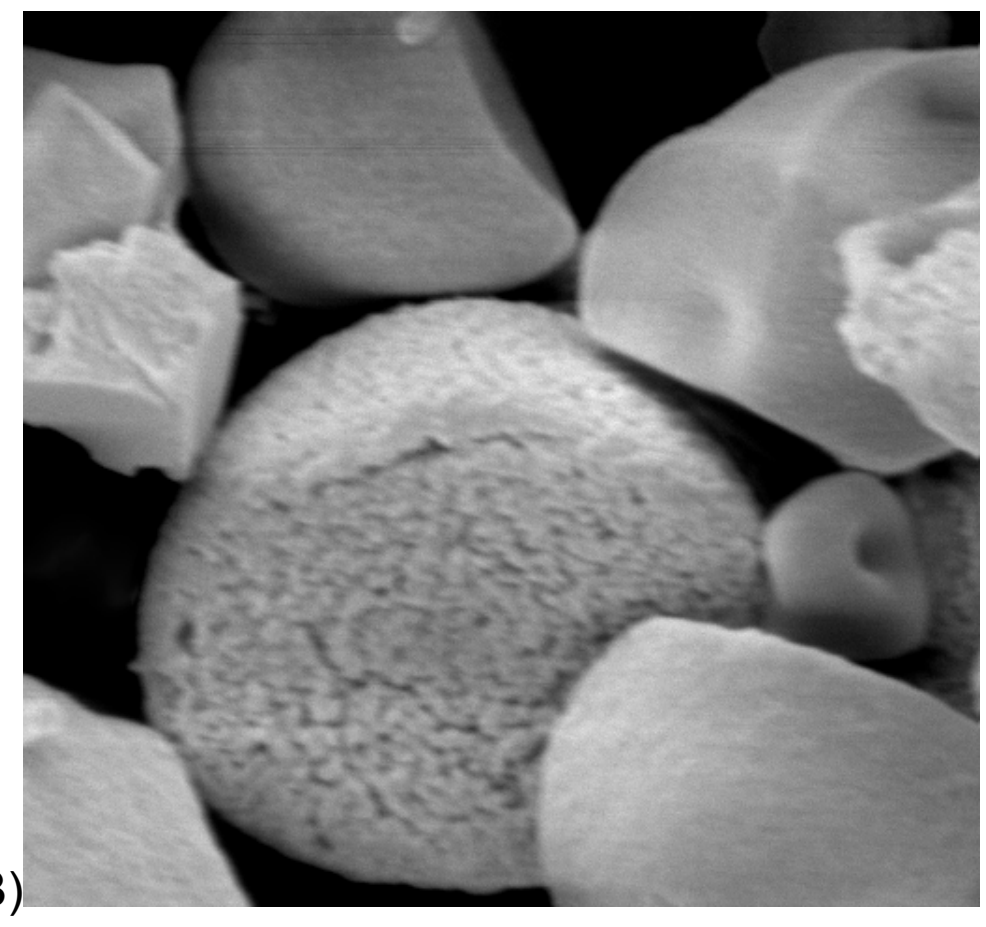

Figura 31 - Fotos dos amidos de batata-doce tratados termicamente sob baixa umidade, após digestão enzimática, em microscópio eletrônico de varredura $(15 \mathrm{kV} / 12 \mathrm{~mm})$ 
Os amidos regulares de batata-doce apresentaram grânulos com formatos e tamanhos característicos da espécie, com aspecto superficial liso (fotos da Figura 28). Pelas fotos da Figura 29 observa-se a aparência desse amido após digestão enzimática. Embora as enzimas e concentração de uso das mesmas sejam idênticas ao que foi utilizado para o amido de mandioquinha-salsa natural, o padrão de ação enzimático sobre o amido de batata-doce se mostrou diferenciado. Os grânulos de amido natural digeridos enzimaticamente apresentaram aspecto superficial poroso, alguns com orifícios de tamanho pequeno e numerosos, outros com orifícios maiores e menos numerosos, alguns orifícios foram mais profundos, outros mais superficiais. Ocorreu também para alguns grânulos uma extensiva corrosão através de canais radiais.

As fotos da Figura 30 apresentam os grânulos de amido de batata-doce tratados com calor e baixa umidade, que não mostraram diferenças visuais ao microscópio eletrônico quando comparados com os grânulos de amido natural. Alguns poucos grânulos, entretanto, apresentaram pequenas fissuras.

O efeito das enzimas sobre o amido de batata doce submetido ao tratamento térmico sob baixa umidade é apresentado na Figura 31. Grânulos com desgaste superficial intenso foram encontrados. O aspecto predominante do TCBU sobre o amido de batata doce foi o de superfície porosa irregular, desgastada e com a presença de fissuras nos grânulos.

As Figuras 32 e 33 mostram, respectivamente, as fotomicrografias dos grânulos de amido de gengibre natural e de gengibre após 24 horas de digestão pela alfaamilase e amiloglucosidase. As Figuras 34 e 35 mostram, respectivamente, as fotomicrografias dos grânulos de amido de gengibre tratados termicamente sob baixa umidade e o amido de gengibre tratado termicamente sob baixa umidade após 24 horas de digestão pela alfa-amilase e amiloglucosidase. 


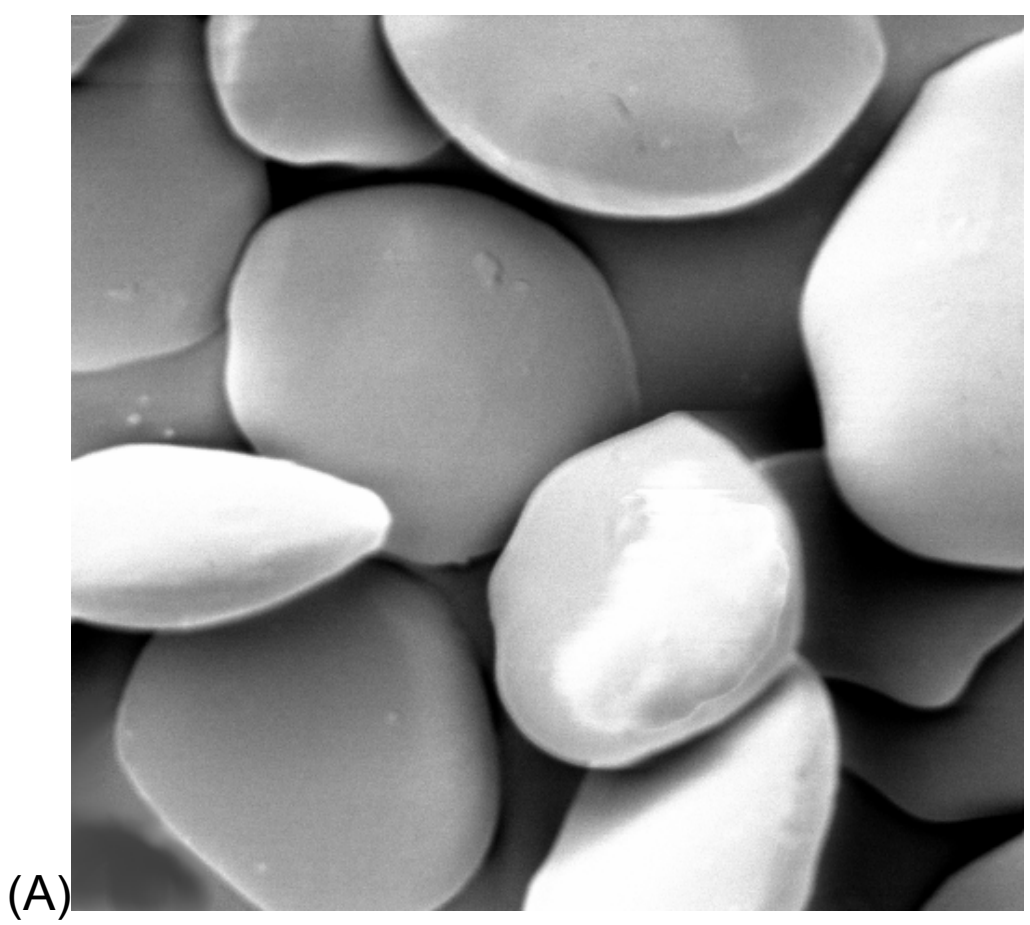

(A)

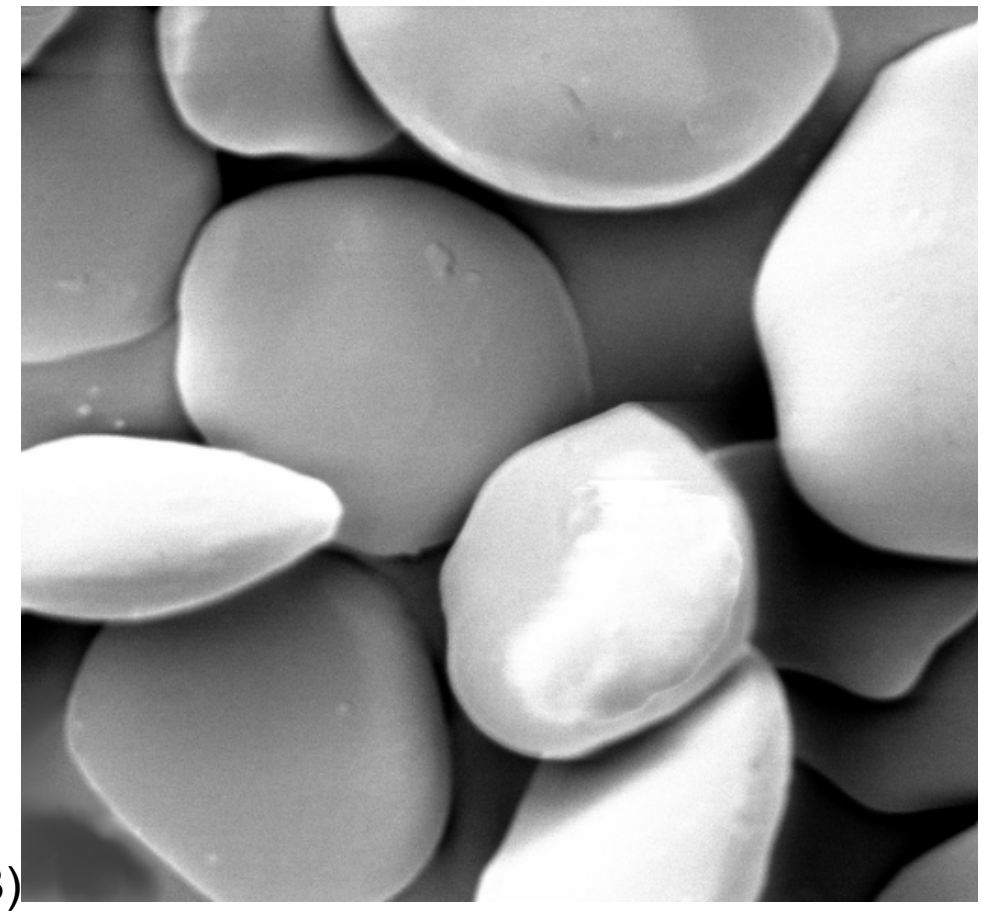

Figura 32 - Fotos dos amidos de gengibre em microscópio eletrônico de varredura $(15 \mathrm{kV} / 12 \mathrm{~mm})$ 


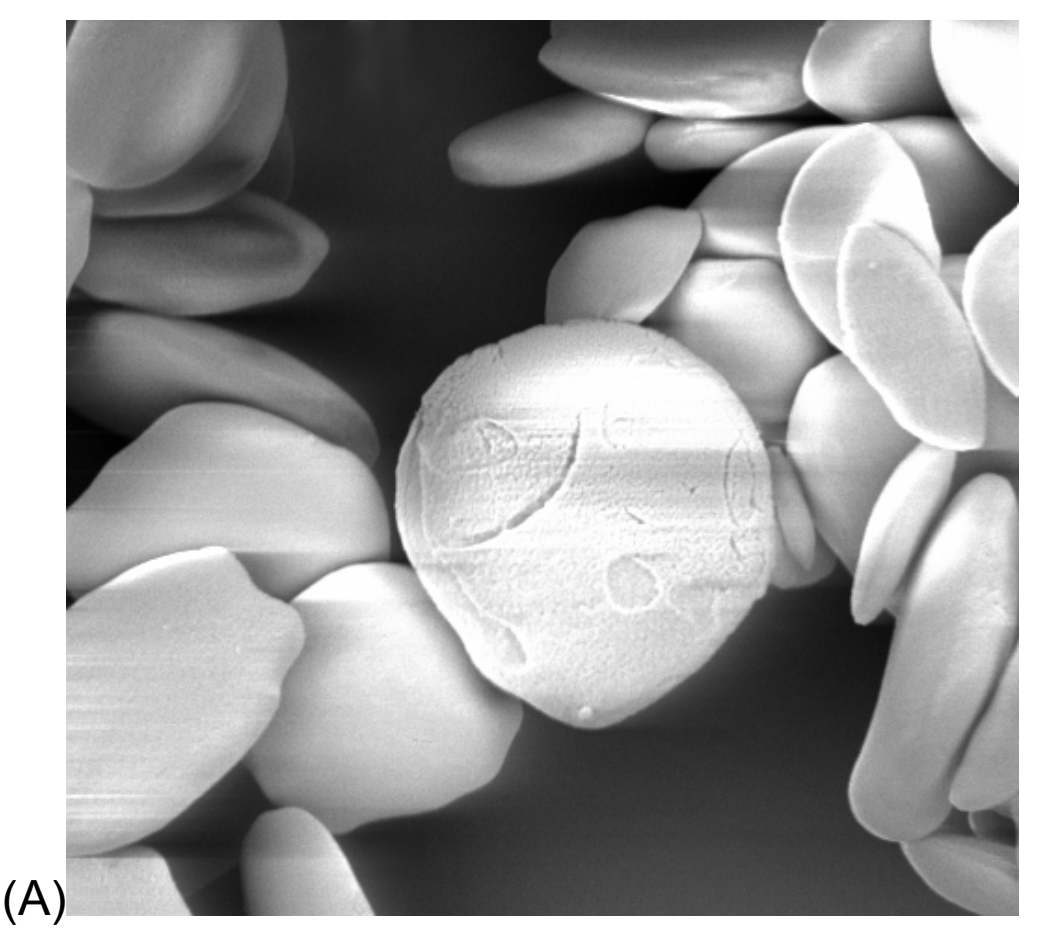

(A)

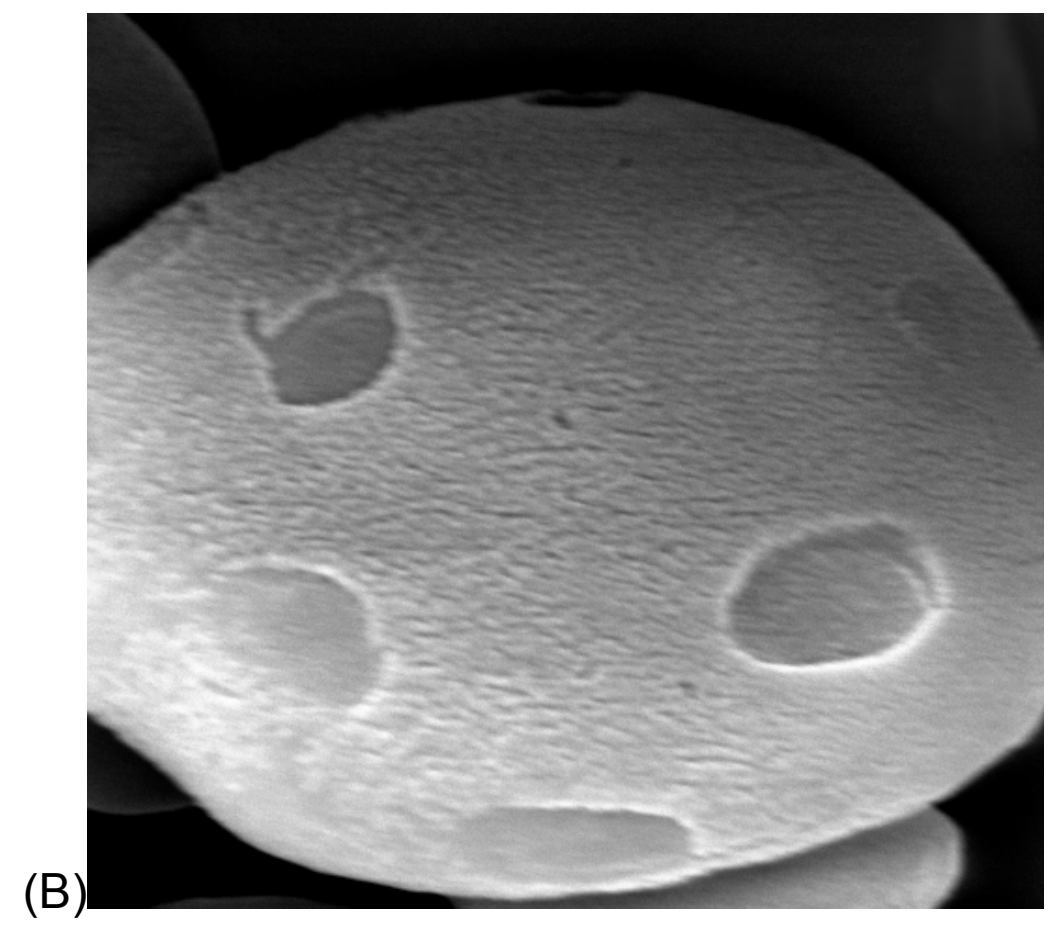

Figura 33 - Fotos dos amidos de gengibre após digestão enzimática, em microscópio eletrônico de varredura 

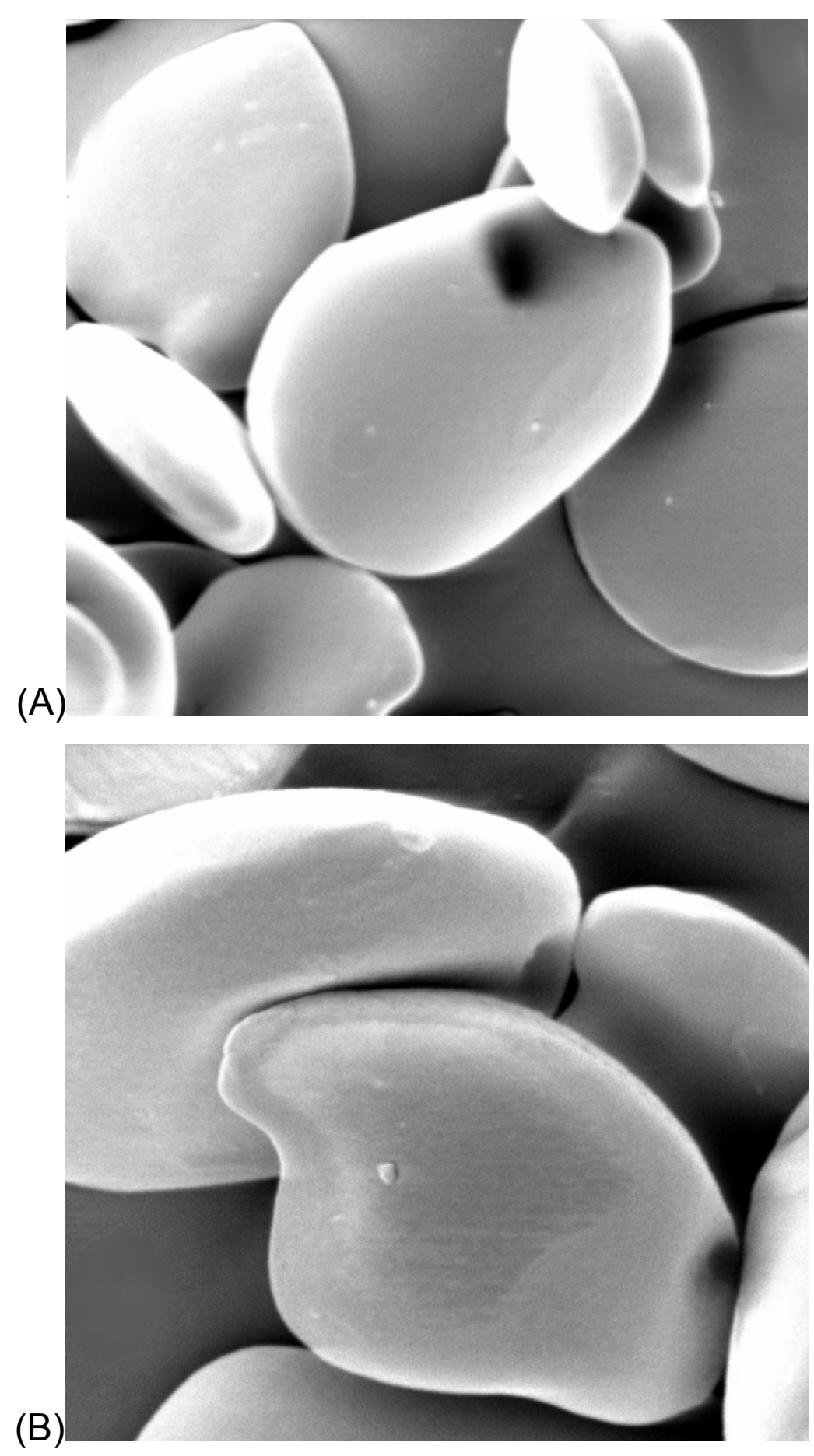

Figura 34 - Fotos dos amidos de gengibre tratados termicamente sob baixa umidade, em microscópio eletrônico de varredura $(15 \mathrm{kV} / 12 \mathrm{~mm})$ 

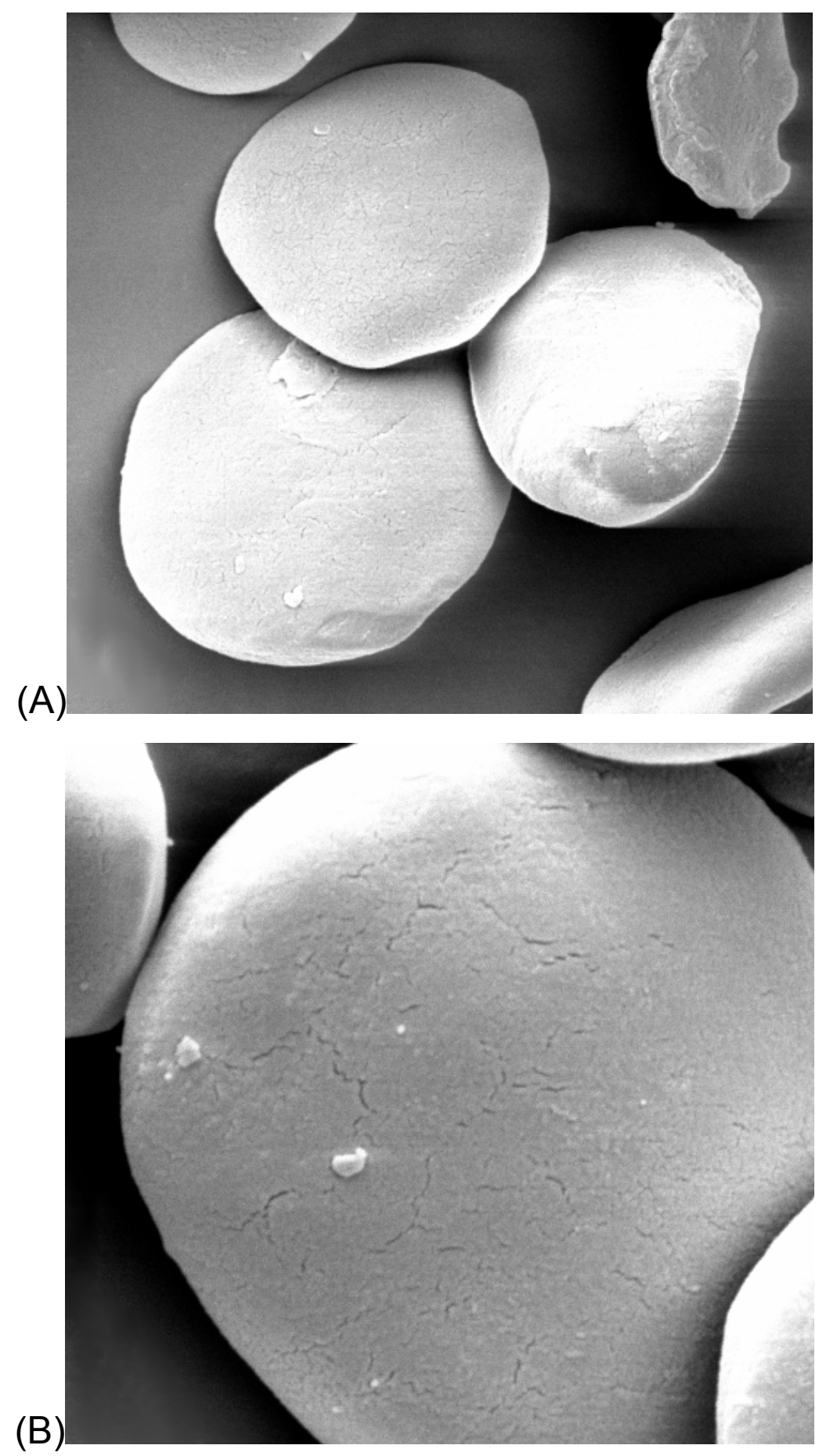

Figura 35 - Fotos dos amidos de gengibre tratados termicamente sob baixa umidade, após digestão enzimática, em microscópio eletrônico de varredura $(15 \mathrm{kV} / 12 \mathrm{~mm})$ 
Pelas fotos da Figura 32 o amido de gengibre natural apresenta grânulos com formatos arredondados e achatados, característicos desta espécie. Este aspecto da espessura pôde ser visualizado pelo microscópio eletrônico, que apresenta a terceira dimensão. A superfície granular é lisa. Já as fotos da Figura 33 mostraram o efeito das enzimas alfa-amilase e amiloglucosidas e sobre alguns destes grânulos de amido, os quais apresentaram pequeno número de orifícios superficiais de formato arredondado e tamanho grande, em padrão diferenciado do ataque enzimático aos amidos das demais tuberosas estudadas. O percentual de hidrólise deste amido foi de apenas $15 \%$.

Comparando-se as fotos das Figuras 32 e 34, de amidos de gengibre natural e tratado com calor e baixa umidade, observa-se que não há diferenças no aspecto granular ao microscópio eletrônico, concordando com o que foi verificado por Kulp \& Lorenz (1981) e Franco (1993) ao estudarem o efeito deste tratamento sobre grânulos de outras fontes vegetais.

Pela Figura 35 observa-se que os amidos tratados com calor em baixa umidade e que foram digeridos enzimaticamente não apresentam grande diferenciação quanto ao aspecto superficial quando comparados com os naturais, o que é comprovado pelo pequeno (5\%) aumento de hidrólise ocorrido após o tratamento térmico.

A suscetibilidade dos grânulos de amido ao ataque enzimático é influenciada por vários fatores, entre eles, a proporção amilose/amilopectina, a estrutura cristalina, o tamanho das partículas e a presença de inibidores de enzima (Zhang \& Oates, 1999). Dentre esses fatores os autores acreditam que a estrutura seja o mais importante.

Segundo Rosenthal et al. (1973), durante a ação das enzimas sobre grânulos de amido, podem ser observadas diferentes formas de solubilização. Uma destruição lenta e seletiva sugere uma estrutura contínua e homogênea. Uma extensiva corrosão e fragmentação dos grânulos sugerem estrutura heterogênea devido à presença de poros característicos de cada fonte botânica. No presente trabalho o amido de gengibre poderia ser classificado no grupo dos amidos de estrutura mais homogênea e o de batata-doce no grupo dos mais heterogêneos. 


\subsection{Difração de raios- $X$}

As Figuras 36 a 38 apresentam os difratogramas de raios- $x$ obtidos para os amidos de mandioquinha-salsa, batata-doce e gengibre, respectivamente. Foram avaliados os amidos naturais e os tratados por calor úmido, submetidos ou não à digestão enzimática com alfa-amilase e amiloglucosidase.

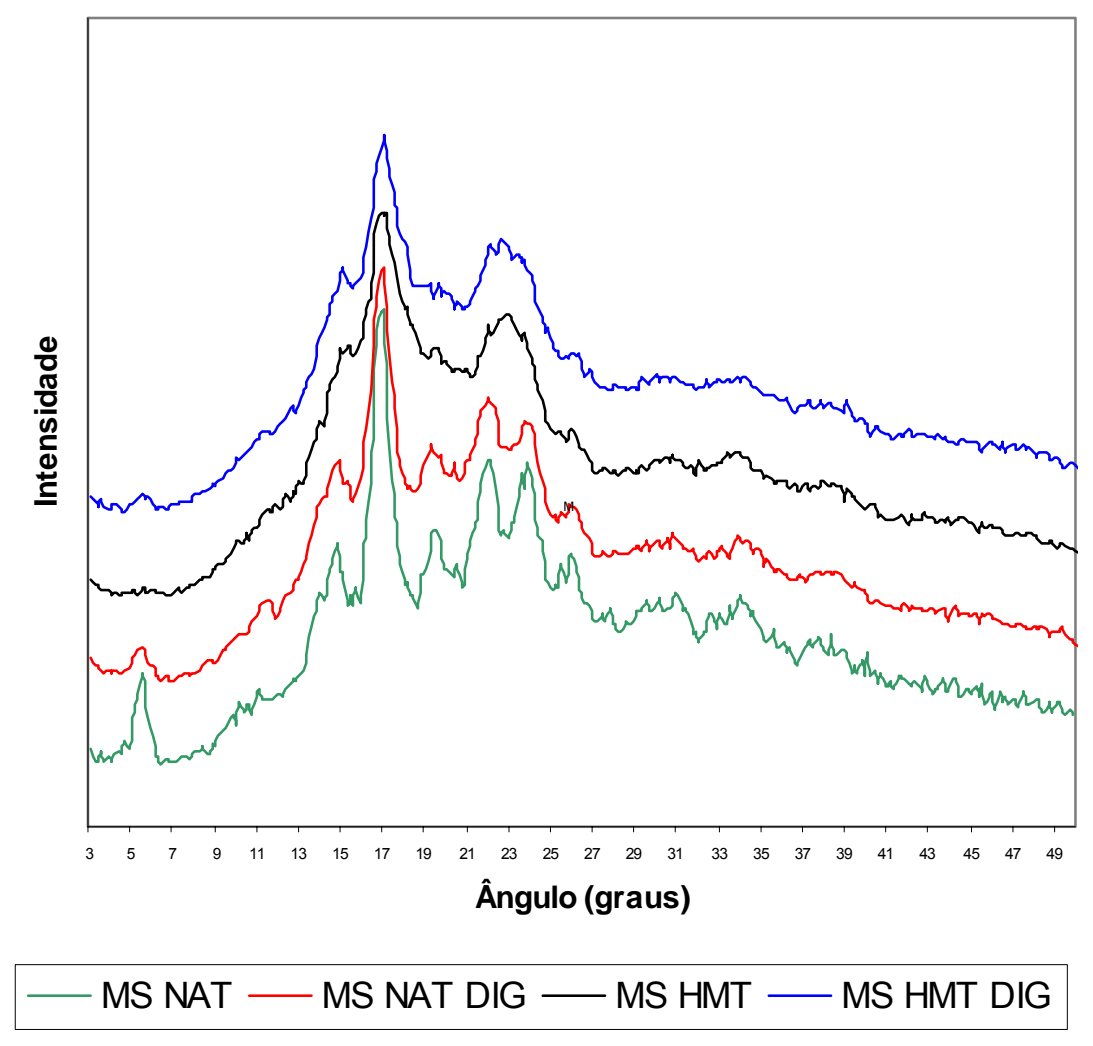

Figura 36 - Perfis de difração de raios-x dos amidos de mandioquinha-salsa natural (NAT), natural submetido a digestão enzimática (NAT DIG), submetido a tratamento térmico em baixa umidade (TCBU) e submetido a tratamento térmico em baixa umidade e digestão enzimática (TCBU DIG) 


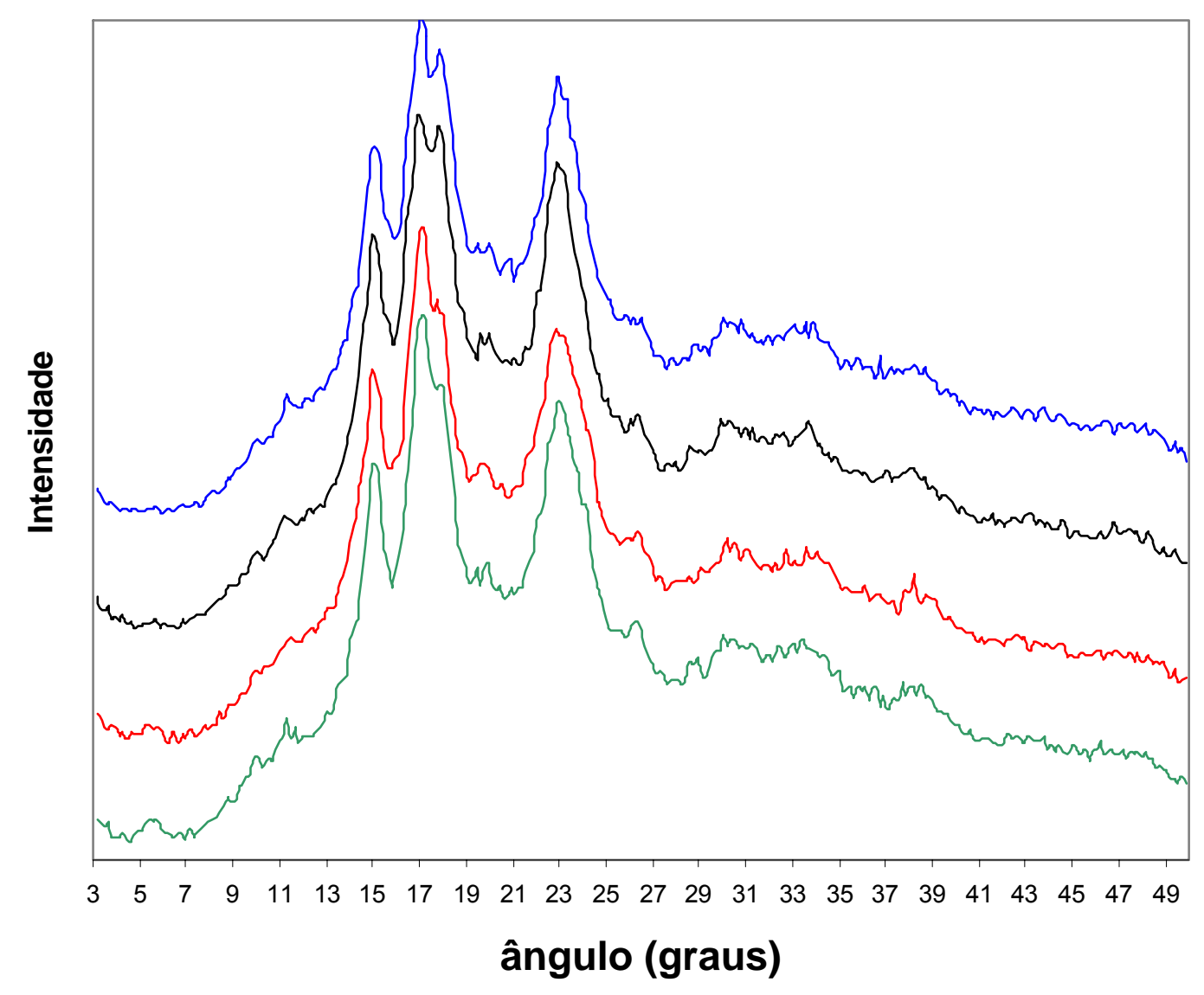

- BD NAT —BD NAT DIG —BD TCBU —BD TCBU DIG

Figura 37 - Perfis de difração de raios-x dos amidos de batata-doce natural (NAT), natural submetido a digestão enzimática (NAT DIG), submetido a tratamento térmico em baixa umidade (TCBU) e submetido a tratamento térmico em baixa umidade e digestão enzimática (TCBU DIG) 


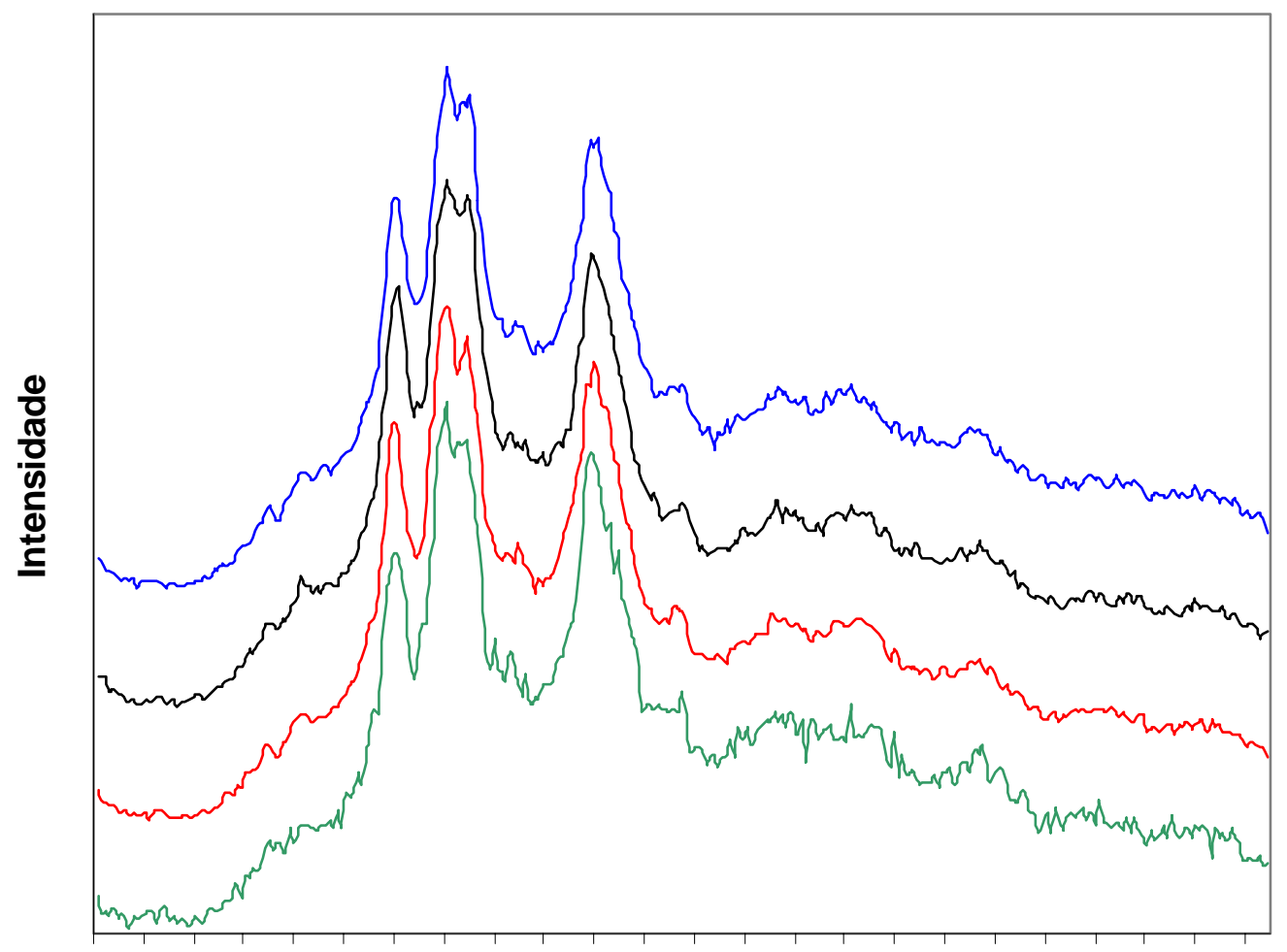

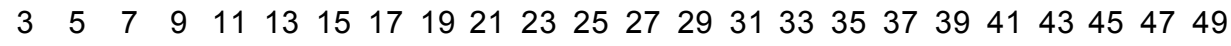
Ângulo (graus)

GENG NAT — GENG NAT DIG — GENG TCBU — GENG TCBU DIG

Figura 38 - Perfis de difração de raios-x dos amidos de gengibre natural (NAT), natural submetido a digestão enzimática (NAT DIG), submetido a tratamento térmico em baixa umidade (TCBU) e submetido a tratamento térmico em baixa umidade e digestão enzimática (TCBU DIG)

As intensidades dos principais picos encontrados nos difratogramas de raios- $\mathrm{X}$ do amido de mandioquinha-salsa, natural e tratado por TCBU, antes e após a digestão enzimática são apresentadas na Tabela 8. 
Tabela 8. Intensidades dos principais picos dos difratogramas de raios-x dos amidos de mandioquinha-salsa, tratados e não tratados com TCBU, antes e após a digestão enzimática

\begin{tabular}{ccccc}
\hline & \multicolumn{4}{c}{ Contagem de picos por segundo (CPS) } \\
Ângulo 2 $\theta$ & Natural & Natural digerido & TCBU & TCBU digerido \\
\hline 5,55 & 146 & 50 & 8 & 23 \\
11,17 & 48 & 121 & 22 & - \\
14,90 & 266 & 286 & 139 & - \\
17,02 & 635 & 615 & 276 & 313 \\
19,27 & 240 & 262 & - & - \\
22,03 & 331 & 313 & 110 & 156 \\
23,99 & 256 & 259 & 125 & 135 \\
26,10 & 121 & 94 & 22 & 30 \\
34,06 & 61 & 53 & - & 19 \\
\hline
\end{tabular}

Pela Figura 36 e Tabela 8 podem ser observadas diferenças nos difratogramas de amido de mandioquinha-salsa com os vários tratamentos, que se deram pela alteração da ocorrência de pico ou pela intensidade dos mesmos. Diferenças menos acentuadas ocorreram com a digestão enzimática e mais acentuadas com o TCBU.

O amido de mandioquinha-salsa natural após a digestão enzimática apresentou picos nos mesmos pontos que os naturais, embora suas intensidades tenham sido alteradas. Tais alterações, contudo não obedeceram tendências, ou seja, alguns picos mostraram-se mais intensos e outros menos intensos após a digestão.

O tratamento térmico alterou de modo expressivo o difratograma do amido de mandioquinha-salsa, que deixou de apresentar alguns dos picos que são importantes na classificação do amido em padrões de cristalinidade definidos pela literatura, com destaque para um dos picos de intensidade média, que deixou de ocorrer aos $19,3^{\circ}$. $O$ tratamento reduziu a intensidade de todos os demais picos ocorridos. A redução dos valores de intensidade com o tratamento térmico efetuado implica, portanto, em 
alterações em zonas semi-cristalinas, com redução de áreas cristalinas ou aumento de zonas amorfas.

Após a digestão enzimática 0 amido de mandioquinha-salsa tratado termicamente deixou de apresentar alguns picos de difração e apresentou pequena elevação de valores nos demais picos ocorridos.

Tabela 9. Intensidades dos principais picos dos difratogramas de raios-x dos amidos de batata-doce, tratados e não tratados com TCBU, antes e após a digestão enzimática

\begin{tabular}{ccccc}
\hline & \multicolumn{4}{c}{ Contagem de picos por segundo (CPS) } \\
Ângulo $2 \theta$ & Natural & Natural digerido & TCBU & TCBUdigerido \\
\hline 5,49 & 23 & 12 & - & - \\
9,85 & 34 & 44 & 12 & 14 \\
11,18 & 46 & - & 35 & 49 \\
14,94 & 296 & 392 & 317 & 253 \\
16,98 & 497 & 586 & 493 & 412 \\
17,90 & 408 & 437 & 449 & 361 \\
19,80 & 159 & 234 & 182 & - \\
22,77 & 376 & 380 & 416 & 256 \\
26,35 & 77 & 77 & 71 & 37 \\
30,06 & - & 38 & 31 & 44 \\
\hline
\end{tabular}

O amido de batata-doce natural, que sofreu um ataque mais intenso das enzimas amilolíticas, apresentou após este tratamento enzimático comportamento diferenciado do amido de mandioquinha-salsa, com elevação de intensidade da maioria dos picos significativos do difratograma, embora tenha perdido o pico no ângulo $11,18^{\circ}$. Tal comportamento sugere um aumento de cristalinidade dos grânulos digeridos. 
Com o TCBU o amido desta raiz deixou de apresentar o pico fraco em $5,5^{\circ}$, teve pequena redução de alguns valores e pequenos incrementos na maioria dos picos críticos, diferindo do comportamento apresentado pelo amido de mandioquinha-salsa. Após a digestão enzimática, esse amido tratado termicamente apresentou redução nas intensidades dos picos.

Tabela 10. Intensidades dos principais picos dos difratogramas de raios-x dos amidos de gengibre, tratados e não tratados com TCBU, antes e após a digestão enzimática

\begin{tabular}{ccccc}
\hline & \multicolumn{4}{c}{ Contagem de picos por segundo (CPS) } \\
Ângulo $2 \theta$ & Natura & Natural digerido & HMT & HMT digerido \\
\hline 5,49 & 26 & - & 21 & - \\
9,89 & 29 & 17 & 27 & 23 \\
10,21 & 42 & 34 & 58 & 36 \\
14,92 & 324 & 313 & 313 & 303 \\
17,03 & 458 & 433 & 408 & 424 \\
17,92 & 365 & 365 & 357 & 361 \\
19,85 & 49 & 79 & - & 55 \\
22,84 & 250 & 253 & 250 & 204 \\
26,45 & 45 & 40 & 31 & 36 \\
30,17 & 30 & - & 35 & 26 \\
\hline
\end{tabular}

O amido de gengibre não apresentou alterações expressivas nas intensidades de pico após a digestão enzimática e também após o tratamento térmico com calor e baixa umidade. Podendo ser considerado, portanto, mais estável a este tratamento a que podem ser submetidos os amidos.

De um modo geral, a intensidade dos picos foi bastante diferenciada entre as fontes de amido estudadas. Os picos mais elevados dos difratogramas de amidos naturais foram os de intensidades de 635, 497 e 433cps, respectivamente para 
mandioquinha-salsa, batata-doce e gengibre. Dentre os amidos estudados, o que parece ter sido mais afetado pelo TCBU foi o de mandioquinha-salsa e o mais afetado pela digestibilidade enzimática foi o de batata-doce. $\mathrm{O}$ amido de gengibre mostrou ser o mais estável frente ao tratamento térmico.

As cinéticas da digestibilidade enzimática do amido de batata-doce natural e também do amido de mandioquinha-salsa tratado termicamente comprovam as alterações observadas nos difratogramas de raios-x nos amidos destas tuberosas.

De acordo com a intensidade dos picos e os espaços interplanares em que ocorreram, os amidos estudados, naturais ou submetidos ao tratamento térmico, puderam ser classificados de acordo com os padrões cristalográficos propostos por Zobel (1988a). Os resultados são apresentados na Tabela 11.

Tabela 11. Padrões de difração de raios-x dos amidos de mandioquinha-salsa, batatadoce e gengibre, sob a forma natural, após tratamento com calor em baixa umidade

\begin{tabular}{ccc}
\hline Amidos & Natural & TCBU \\
\hline Mandioquinha-salsa & B & B \\
Batata-doce & A & A \\
Gengibre & A & A \\
\hline
\end{tabular}

O amido extraído de mandioquinha-salsa apresentou padrão cristalográfico do tipo B, apresentando picos de intensidade médias em 5,55, em 14,9, em 19,3 e 22,0 e em $24,0^{\circ}$ e um pico de intensidade forte em $17,0^{\circ}$. Após o tratamento térmico o amido de mandioquinha perdeu em intensidade o pico a $5,55^{\circ}$, muito embora tenha mantido os outros picos e intensidades relativas que o classificam neste mesmo padrão. Apesar do padrão cristalográfico deste amido não ter sido alterado, nem pelo tratamento com calor em baixa umidade, nem pela digestão enzimática, os perfis apresentaram-se diferenciados. 
O amido extraído de batata-doce apresentou padrão cristalográfico tipo $A$, apresentando picos fortes em 17,0, 17,9 e 22,8 $8^{\circ}$ e médios em 15,0, 19,8 . Hoover (2001) também classificou o amido desta raiz como sendo do tipo $A$.

Após o tratamento térmico, o amido de batata-doce perdeu o pico a $5,49^{\circ} \mathrm{e}$ apresentou aumento dos valores de intensidade de pico, entretanto, manteve a maioria dos picos nos espaços interplanares em que ocorrem e com intensidades relativas similares, podendo ser classificado como de mesmo padrão de cristalinidade do amido quando natural.

O amido de gengibre natural apresentou picos de intensidade forte a 17,0 e $17,9^{\circ}$, pico de intensidade média a forte a $14,9^{\circ}$ e pico de intensidade média a $22,8^{\circ}$, o que permite a classificação deste amido no padrão de cristalinidade do tipo $A$. $O$ tratamento com calor em baixa umidade não afetou o padrão cristalográfico deste amido.

French (1984) estudando o efeito do tratamento com calor sob baixa umidade $\left(100^{\circ} \mathrm{C} / 16 \mathrm{horas} / 35 \%\right.$ de umidade) sobre amido de batata, observou mudança do padrão de difração de raios-x de B para A. O autor deduziu que durante este tratamento ocorreu que os cristais se fundiram e se recristalizaram.

O tratamento com TCBU promove interação das cadeias poliméricas, rompimento da estrutura cristalina e dissociação das estruturas de duplas hélices presentes na região amorfa do grânulo. A extensão dessas alterações estruturais é mais pronunciada nos amidos com padrão de raios-x do tipo B (Gunaratne \& Hoover, 2002). Este fato foi confirmado no presente trabalho porque o amido de mandioquinhasalsa (padrão B) sofreu mais o impacto deste tratamento, o que pode ser deduzido das alterações nas intensidades de pico e digestibilidade enzimática diferenciada.

Segundo Rosenthal et al. (1973) os amidos com padrão de difração de raios-X tipo B são os mais rapidamente são atacados pelas enzimas, o que segundo o autor, sugere heterogeneidade dentro do grânulo com regiões resistentes separadas por áreas mais abertas e acessíveis. Isso tem sido explicado através da existência de micelas cristalinas fortemente associadas que são separadas por regiões intermicelares, amorfas. Os amidos que apresentam tipo A ou C são mais resistentes ao ataque enzimático, o que sugere grânulos mais homogêneos com relação à distribuição de forças internas de ligação. 


\subsection{Propriedades de pasta dos amidos}

Os amidos de mandioquinha-salsa, batata-doce e gengibre naturais e tratados termicamente sob baixa umidade, submetidos à digestão enzimática ou não, foram avaliados pelo RVA e os perfis podem ser visualizados pelas Figuras 39, 40 e 41, respectivamente.

Os perfis de viscosidade dos amidos naturais de mandioquinha-salsa e batatadoce foram semelhantes quanto ao formato e valores, apresentando picos agudos. Apresentaram também consideráveis quedas de viscosidade, indicativas de fragilidade dos grânulos que, inchados em excesso, quebram-se perdendo viscosidade. A tendência a retrogradação do amido de mandioquinha-salsa natural mostrou-se muito discreta.

O amido de gengibre natural apresentou perfil diferenciado dos demais, com início de empastamento posterior, valores inferiores de viscosidade, não apresentou quebra, o que indica elevada estabilidade em temperaturas elevadas sob agitação, além de tendência moderada a retrogradação com o resfriamento.

O processo de digestão enzimática dos grânulos de amido estudados causou redução nos picos de viscosidade de todos os amidos naturais, como esperado, uma vez que as enzimas reduzem o tamanho das macromoléculas de amido. Entretanto, esta redução aconteceu em diferentes intensidades, confirmando a suscetibilidade enzimática diferenciada.

O tratamento com calor em baixa umidade provocou alterações intensas em todos os amidos estudados, modificando significativamente o perfil viscoamilográfico obtido para os amidos naturais. Houve alteração nos formatos das curvas e nos valores de viscosidade. Os perfis dos amidos de mandioquinha e de batata-doce tratados termicamente tornaram-se parecidos com o de gengibre natural, ou seja, apresentaram temperaturas de pasta elevadas e picos de viscosidade não bem definidos. $O$ amido de gengibre tratado termicamente apresentou perfil similar ao natural, entretanto, com valores de viscosidade bem inferiores. 


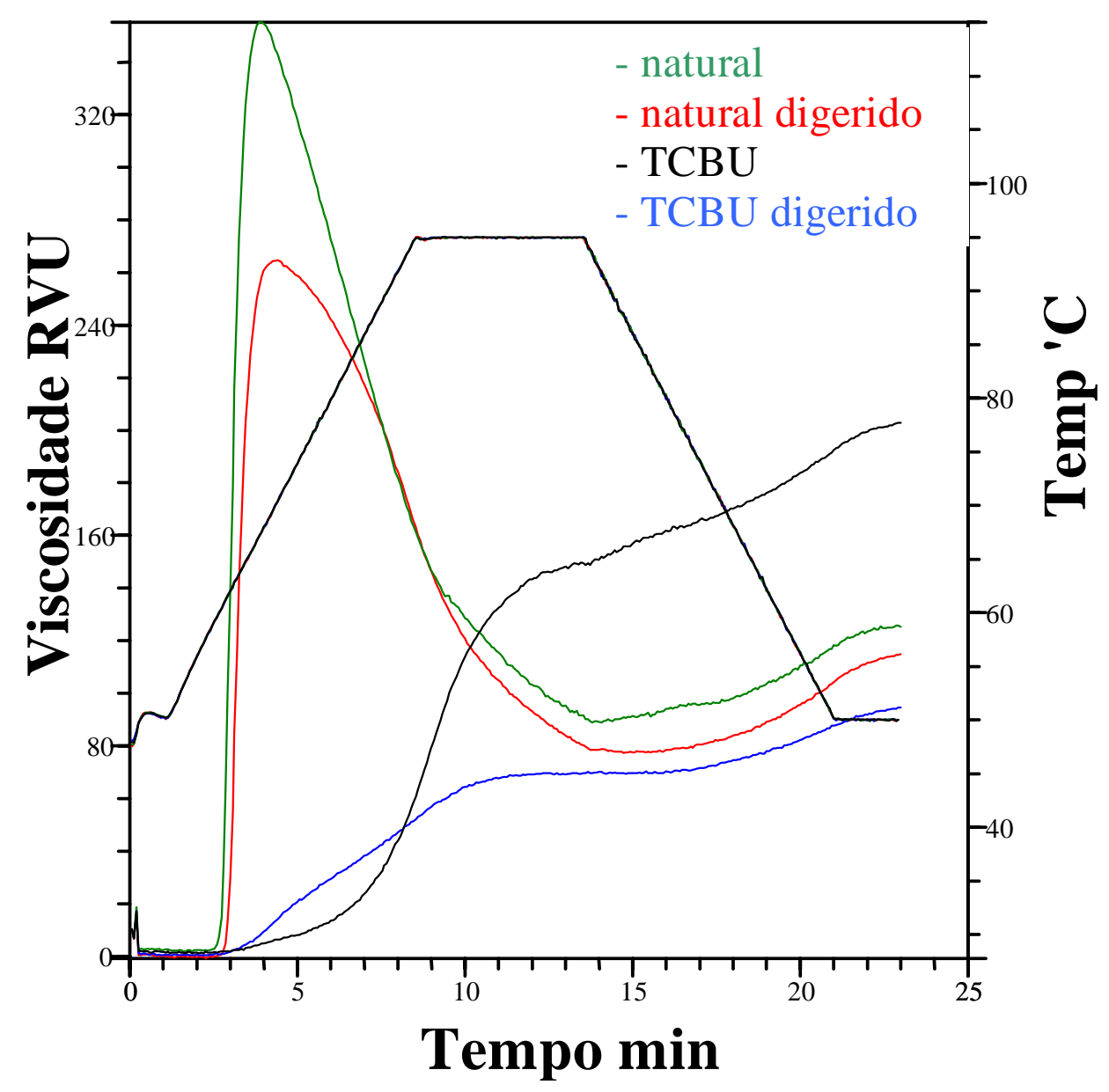

Figura 39 - Perfis viscoamilográficos do amido extraído de mandioquinha-salsa (natural) e após sua digestão enzimática (natural digerido), tratado termicamente em baixa umidade (TCBU), e tratado termicamente em baixa umidade após a digestão enzimática (TCBU digerido) 


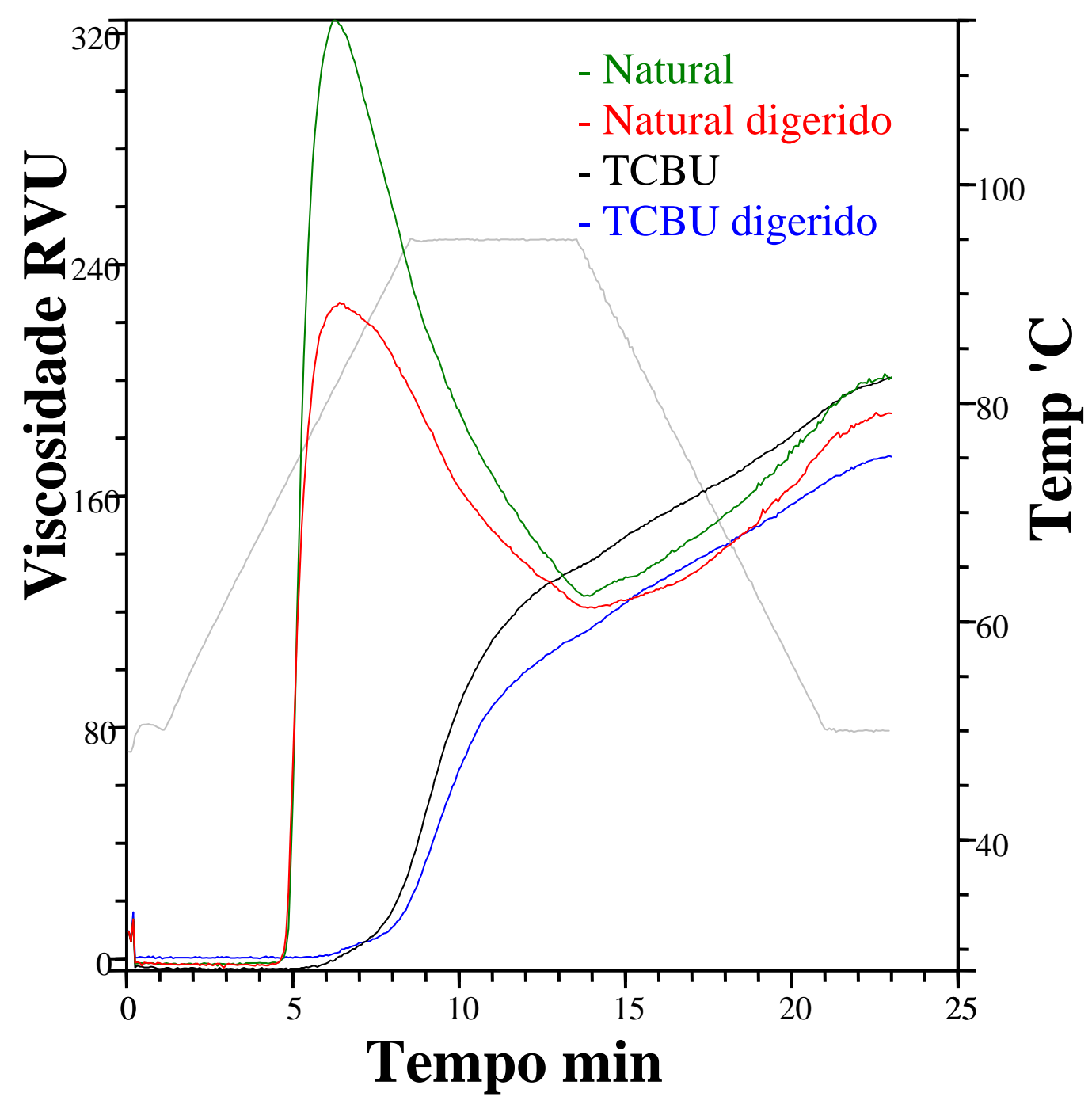

Figura 40 - Perfis viscoamilográficos do amido de batata-doce (natural) e após sua digestão enzimática (natural digerido), tratado termicamente em baixa umidade (TCBU), e tratado termicamente em baixa umidade após a digestão enzimática (TCBU digerido) 


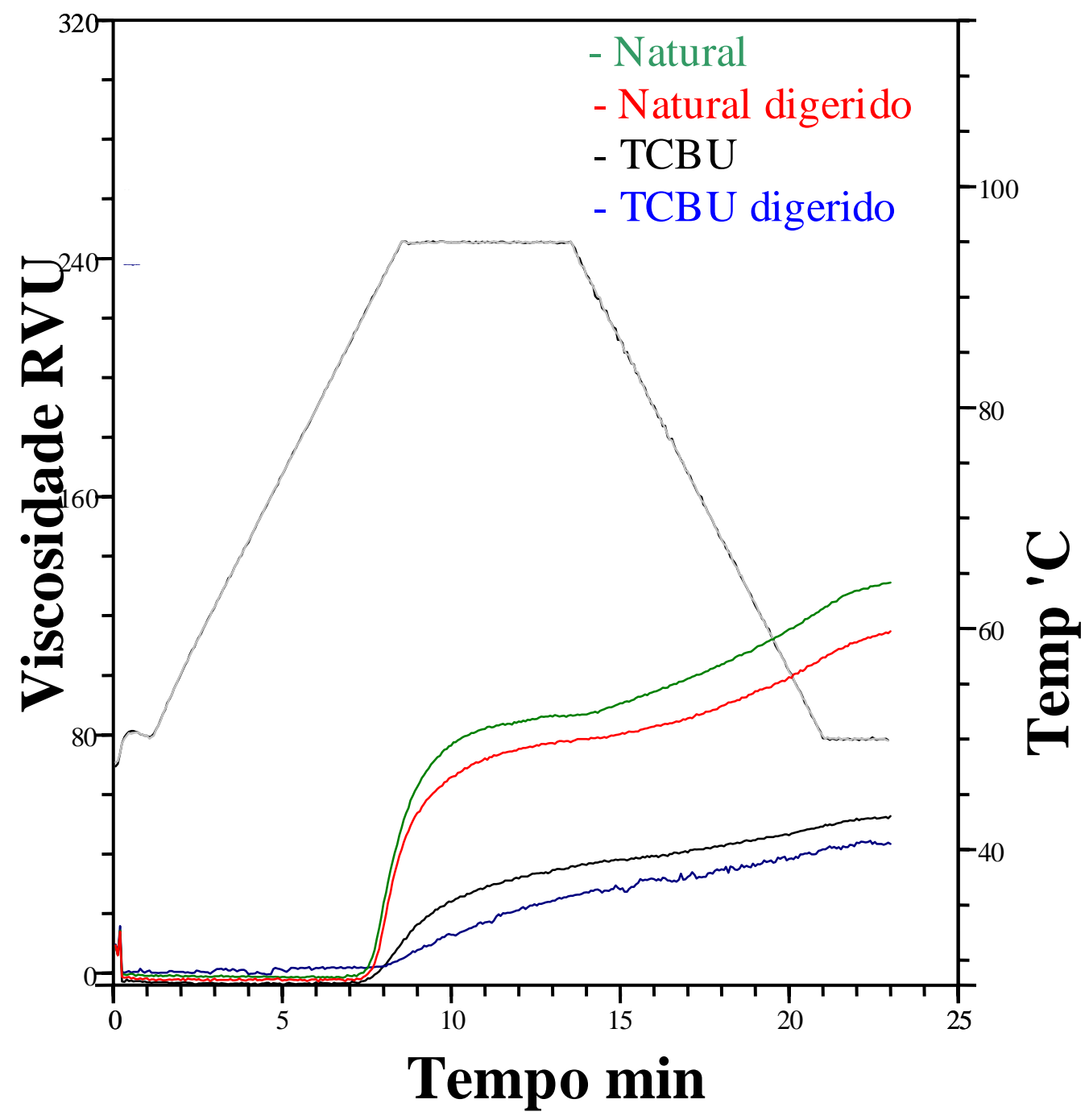

Figura 41 - Perfis viscoamilográficos do amido de gengibre (natural) e após sua digestão enzimática (natural digerido), tratado termicamente em baixa umidade (TCBU), e tratado termicamente em baixa umidade após a digestão enzimática (TCBU digerido) 
O tratamento com calor em baixa umidade aumentou a suscetibilidade dos grânulos ao ataque enzimático e isto teve reflexo na produção de viscosidade. O amido de mandioquinha-salsa apresentou grande diferença na intensidade dos picos de viscosidade entre os amidos submetidos a este tratamento, antes e após a digestão enzimática.

Kulp \& Lorenz (1981) estudando amidos de trigo e batata tratados termicamente sob baixa umidade $\left(100^{\circ} \mathrm{C} / 16\right.$ horas / 27\%umidade) observaram aumento na temperatura de gelatinização e redução do poder de inchamento. Este comportamento também foi observado para os amidos de mandioquinha-salsa, batata-doce e gengibre tratados sob as mesmas condições de temperatura, tempo e umidade no presente trabalho. Segundo Kulp \& Lorenz (1981) a diminuição do poder de inchamento sugere que o tratamento com TCBU tenha ocasionado mudanças na estrutura das regiões amorfas do grânulo.

As propriedades de pasta do amido mandioquinha-salsa natural e tratado termicamente sob baixa umidade, submetido à digestão enzimática ou não são apresentadas na Tabela 12.

O amido de mandioquinha-salsa natural apresentou baixa temperatura de pasta e baixo tempo para atingir o pico, fatos que indicam que este amido apresenta cozimento mais fácil que os demais. Após um considerável pico de viscosidade, houve também grande quebra, o que demonstra sua suscetibilidade à ruptura dos grânulos quando submetidos ao aquecimento e à agitação mecânica.

Todos os valores de viscosidade encontrados para amido de mandioquinha-salsa natural foram similares aos encontrados por Peroni (2003) para amido desta mesma fonte, operando o viscógrafo sob as mesmas condições. 
Tabela 12. Propriedades de pasta de suspensões $(2,5 \mathrm{~g} / 25 \mathrm{~mL}$ água) de amido extraído de mandioquinha-salsa (natural) e após digestão enzimática (natural digerido), após tratamento com calor em baixa umidade (TCBU) e após tratamento com calor em baixa umidade e digestão enzimática (TCBU digerido)

\begin{tabular}{|c|c|c|c|c|c|c|}
\hline & \multicolumn{4}{|c|}{ Viscosidade (RVU) } & \multirow{2}{*}{$\begin{array}{c}\text { Temperatura } \\
\text { de pasta * } \\
\left({ }^{\circ} \mathrm{C}\right)\end{array}$} & \multirow{2}{*}{$\begin{array}{c}\text { Tempo } \\
\text { de } \\
\text { pico } \\
\text { (min) }\end{array}$} \\
\hline & Pico & quebra & Final & Tend. Retro. & & \\
\hline Natural & $353 \pm 1,5^{a}$ & $265 \pm, 0^{a}$ & $149 \pm 1,6^{a}$ & $37 \pm 1,1^{a}$ & $59 \pm 0,5^{a}$ & $3,9 \pm 0,1^{a}$ \\
\hline $\begin{array}{l}\text { Natural } \\
\text { digerido }\end{array}$ & $261 \pm 4,1^{\mathrm{b}}$ & $183 \pm 4,4^{b}$ & $116 \pm 1,2^{b}$ & $38 \pm 1,2^{a}$ & $61 \pm 0,7^{a}$ & $4,4 \pm 0,1^{a}$ \\
\hline TCBU & $151 \pm 2,8^{c}$ & $0,5 \pm 0,01^{c}$ & $187 \pm 1,6^{c}$ & $56 \pm 0,5^{b}$ & $63 \pm 1,8^{a}$ & $13 \pm 0,2^{b}$ \\
\hline $\begin{array}{l}\text { TCBU } \\
\text { digerido }\end{array}$ & $75 \pm 5,7^{d}$ & $0,4 \pm 0,02^{c}$ & $97 \pm 3,0^{d}$ & $28 \pm 2,7^{c}$ & $60 \pm 2,7^{a}$ & $12,3 \pm 0,2^{b}$ \\
\hline
\end{tabular}

Nota: médias com letras diferentes dentro da mesma coluna diferiram significativamente entre si em nível de $5 \%$ pelo teste de Tukey

O tratamento com calor e baixa umidade (TCBU) alterou significativamente as características de pasta do amido de mandioquinha-salsa natural. O tempo para ocorrência do pico de viscosidade desse amido aumentou consideravelmente, o seu pico de viscosidade foi reduzido a menos da metade e a quebra de viscosidade deixou de existir, ou seja, o tratamento tornou o amido menos susceptível a ruptura dos grânulos em temperaturas elevadas e sob agitação mecânica. A viscosidade final do amido foi elevada e a tendência de retrogradação se tornou mais acentuada comparativamente ao amido não tratado. O único parâmetro não afetado pelo tratamento foi a temperatura de pasta. 
As propriedades de pasta do amido batata-doce natural e tratado termicamente sob baixa umidade, submetido à digestão enzimática ou não são apresentadas na Tabela 13.

Tabela 13. Propriedades de pasta de suspensões $(2,5 \mathrm{~g} / 25 \mathrm{~mL}$ água) de amido extraído de batata-doce (natural) e após a digestão enzimática (natural digerido), após tratamento com calor em baixa umidade (TCBU), e após tratamento com calor em baixa umidade e digestão enzimática (TCBU digerido)

\begin{tabular}{|c|c|c|c|c|c|c|}
\hline & \multicolumn{4}{|c|}{ Viscosidade (RVU) } & \multirow{2}{*}{$\begin{array}{c}\text { Temperatura } \\
\text { de pasta * } \\
\left({ }^{\circ} \mathrm{C}\right)\end{array}$} & \multirow{2}{*}{$\begin{array}{c}\text { Tempo de } \\
\text { pico } \\
\text { (min) }\end{array}$} \\
\hline & Pico & quebra & Final & end. Retro. & & \\
\hline Natural & $345 \pm 0,2^{a}$ & $205 \pm 0,4^{a}$ & $201 \pm 0,3^{a}$ & $76 \pm 0,3^{a}$ & $72 \pm 0,04^{a}$ & $6,3 \pm 0,00^{a}$ \\
\hline $\begin{array}{l}\text { Natural } \\
\text { digerido }\end{array}$ & $247 \pm 0,1^{b}$ & $118 \pm 2,1^{b}$ & $199 \pm 1,0^{a}$ & $69 \pm 2,1^{b}$ & $72 \pm 0,1^{a}$ & $6,5 \pm 0,07^{b}$ \\
\hline TCBU & $120 \pm 1,2^{c}$ & $-1 \pm 0,2^{c}$ & $199 \pm 1,3^{a}$ & $69 \pm 0,3^{b}$ & $94 \pm 1,1^{\mathrm{b}}$ & $13,0 \pm 0,00^{c}$ \\
\hline $\begin{array}{c}\text { TCBU } \\
\text { digerido }\end{array}$ & $108 \pm 0,2^{d}$ & $-1 \pm 0,1^{c}$ & $173 \pm 0,2^{b}$ & $65 \pm 0,1^{c}$ & $95 \pm 0,001^{b}$ & $13,0 \pm 0,00^{c}$ \\
\hline
\end{tabular}

- Letras diferentes na mesma coluna significa que há diferença significativa em nível de $5 \%$ segundo o teste de Tukey

Os valores de viscosidade máxima e de quebra encontrados para amido de batatadoce natural foram superiores aos encontrados por Peroni (2003) e os demais valores são próximos.

Segundo Takeda et al. (1986) o amido de batata-doce apresenta alta resistência à desintegração mecânica durante o processo de gelificação, fato não observado o presente trabalho, já que os valores de quebra encontrados para o amido de batata-doce natural foram elevados. 
O amido da batata-doce após o tratamento pelo calor em baixa umidade também teve suas propriedades de pasta consideravelmente afetadas. Para este amido houve alteração na temperatura de pasta, tempo para ocorrência do pico, valor de viscosidade máxima e tendência a retrogradação. Houve ainda considerável aumento da resistência térmica e mecânica do amido, o que pode ser observado pela ausência de quebra de viscosidade. Após este tratamento o amido de batata-doce não apresentou alteração apenas na viscosidade final.

Algumas das tendências de alteração no caso deste amido foram as mesmas observadas para o amido de mandioquinha-salsa, ou seja, aumento do tempo para ocorrência do pico e redução da viscosidade máxima para menos da metade do valor obtido para o amido natural. Foram opostos os comportamentos da tendência a retrogradação. Segundo Sriroth et al. (2002) o amido de mandioca tratado termicamente sob baixa umidade também diminui a tendência a retrogradação das pastas.

As propriedades de pasta do amido gengibre natural e tratado termicamente sob baixa umidade, submetido à digestão enzimática ou não são apresentadas na Tabela 14.

O amido natural de gengibre apresentou valores de viscosidade máxima e final superiores aos obtidos por Peroni (2003), contudo a quebra, retrogradação, temperatura de pasta e tempo de pico foram semelhantes.

A quebra de viscosidade do amido de gengibre natural foi próxima de zero, demonstrando elevada estabilidade térmica e mecânica. Este resultado está em conformidade com as afirmações de Reyes et al. (1982) para o qual o amido de gengibre apresenta elevada resistência às temperaturas elevadas, alta resistência à agitação mecânica e, resistência ao cozimento à temperatura constante. Os autores associaram tais fatos ao alto grau de associação entre os componentes formadores desse amido e também ao seu elevado teor de amilose. 
Tabela 14. Propriedades de pasta de suspensões $(2,5 \mathrm{~g} / 25 \mathrm{~mL}$ água) de amido extraído de gengibre (natural) e após a digestão enzimática (natural digerido), após tratamento com calor em baixa umidade (TCBU), e após tratamento com calor em baixa umidade e digestão enzimática (TCBU digerido)

\begin{tabular}{|c|c|c|c|c|c|c|}
\hline & \multicolumn{4}{|c|}{ Viscosidade (RVU) } & \multirow{2}{*}{$\begin{array}{c}\text { Temperatura } \\
\text { de pasta * } \\
\left({ }^{\circ} \mathrm{C}\right)\end{array}$} & \multirow{2}{*}{$\begin{array}{c}\text { Tempo de } \\
\text { pico } \\
(\min )\end{array}$} \\
\hline & Pico & quebra & Final & Tend. Retro. & & \\
\hline Natural & $98 \pm 2,3^{a}$ & $0,48 \pm 0,05^{\mathrm{a}}$ & $140 \pm 3,7^{\mathrm{a}}$ & $43 \pm 1,5^{\mathrm{a}}$ & $93,9 \pm 0,5^{a}$ & $12,8 \pm 0,1^{a}$ \\
\hline $\begin{array}{l}\text { Natural } \\
\text { digerido }\end{array}$ & $84 \pm 1,1^{b}$ & $0,35 \pm 0,08^{b}$ & $121 \pm 1,5^{b}$ & $37 \pm 0,2^{b}$ & $92,9 \pm 1,4^{a}$ & $12,9 \pm 0,1^{a}$ \\
\hline TCBU & $32 \pm 2,7^{\mathrm{c}}$ & $0^{c}$ & $51 \pm 2,1^{\mathrm{c}}$ & $19 \pm 0,6^{c}$ & $92,4 \pm 1,2^{\mathrm{a}}$ & $13,0 \pm 0,00^{a}$ \\
\hline $\begin{array}{l}\text { TCBU } \\
\text { digerido }\end{array}$ & $25 \pm 0,9^{d}$ & $0^{c}$ & $44 \pm 1,4^{d}$ & $19 \pm 0,3^{c}$ & $95,0 \pm 1,1^{\mathrm{a}}$ & $13,1 \pm 000^{a}$ \\
\hline
\end{tabular}

- Letras diferentes na mesma coluna significa que há diferença significativa em nível de $5 \%$ segundo o teste de Tukey

O tratamento térmico em baixa umidade alterou as propriedades de pasta do amido de gengibre natural. A elevada temperatura de pasta demonstra maior dificuldade de cozimento desse amido. Os amidos de gengibre tratados apresentaram picos significativamente menores que os não tratados (redução à cerca de um terço do valor observado para o amido natural) e valores de quebra também próximos do zero. A viscosidade final também foi reduzida significativamente, junto com tendência a retrogradação. $\mathrm{O}$ tratamento não alterou o tempo de ocorrência do pico.

De acordo com Thomas \& Atwell (1999) o tratamento com calor em baixa umidade proporciona aos amidos uma melhoria na consistência e também na estabilidade da viscosidade, até mesmo em valores de $\mathrm{pH}$ menores que 4,5.

A afirmação de Gunaratne \& Hoover (2002) de que o TCBU pode ser uma alternativa às modificações químicas para alterar as propriedades de geleificação e retrogradação dos amidos de raízes e tubérculos, encontra respaldo no presente 
trabalho. Embora as modificações nem sempre sigam o mesmo padrão, contudo, alguns parâmetros apresentaram uniformidade de comportamento, ou seja, este tratamento promove aumento na temperatura de pasta, redução considerável de viscosidade e aumento de estabilidade a elevadas temperaturas sob agitação mecânica. 


\section{CONCLUSÕES}

Considerando a avaliação dos amidos das diferentes fontes botânicas no presente trabalho, antes e após o tratamento térmico sob baixa umidade $\left(100^{\circ} \mathrm{C} / 27 \%\right.$ de umidade/ 16 horas), pode-se concluir que:

* O tratamento com calor em baixa umidade aumentou a suscetibilidade enzimática de todos os amidos estudados, o que provavelmente foi provocado pelo rearranjo dos cristais rompidos durante o tratamento, aumentando as áreas acessíveis à ação das enzimas. O amido de mandioquinha-salsa natural (17\% de amilose e 0,032\% de fósforo, tamanho médio de grânulo de $12,5 \times 17,3 \mu \mathrm{m}$, padrão $\mathrm{B}$ de cristalinidade) apresentou após o tratamento térmico um aumento expressivo de digestibilidade enzimática. O amido de batata-doce natural $(22 \%$ de amilose, 0,027\% de fósforo, tamanho médio de grânulo de $20,4 \times 26,2 \mu \mathrm{m}$, padrão $A$ de cristalinidade) apresentou após o tratamento térmico o menor aumento de suscetibilidade a ação enzimática, provavelmente em decorrência da elevada suscetibilidade do amido natural. O amido de gengibre natural (25\% de amilose, 0,022\% de fósforo, tamanho médio de grânulos de $17,6 \times 23,2 \mu \mathrm{m}$, padrão $\mathrm{A}$ de cristalinidade) apresentou um abaixo percentual de digestão enzimática e após o tratamento térmico mostrou um aumento intermediário de percentual de digestão enzimática.

* O aspecto dos amidos avaliados por microscopia eletrônica de varredura mostrou que o ataque pela alfa-amilase bacteriana e glucoamilase fúngica provocou corrosões nos grânulos, com padrões de ação diferenciados. Dentre os grânulos, alguns não apresentaram sinais visíveis de ataque enzimático, outros apresentaram pequenos orifícios na superfície dos mesmos ou mesmo um desgaste superficial extensivo e outros ainda, apresentaram corrosão mais intensa, mostrando orifícios mais profundos ou até estrutura aberta, com camadas 
concêntricas visíveis. A intensidade de ataque aos grânulos acompanhou a intensidade das alterações ocorridas com a fonte de amido ou com o TCBU.

* Todos os amidos tratados com calor em baixa umidade apresentaram alterações estruturais percebidas pelos perfis de difração de raios-x (ocorrência e intensidade de picos), entretanto, estas não foram suficientes para mudar os padrões de cristalinidade obtidos para os amidos correspondentes, não tratados. Houve redução da cristalinidade dos grânulos de amido da mandioquinha-salsa e do gengibre com o tratamento térmico, mostrado pela redução dos valores de intensidade dos picos dos difratogramas de raios-x. Esta redução da cristalinidade permitiu maior acesso às enzimas que atuaram digerindo mais os amidos. $A$ redução das intensidades de pico com o tratamento térmico resultaram em aumentos proporcionais dos percentuais de digestibilidade nessas duas fontes de amido. O amido de batata doce tratado termicamente apresentou valores de intensidade de picos próximos aos do amido natural e isto se refletiu em seu baixo aumento da porcentagem de hidrólise após o tratamento térmico.

* Os perfis e valores dos viscoamilogramas dos amidos estudados foram substancialmente alterados com o tratamento térmico em baixa umidade, havendo elevação da temperatura de pasta e do tempo para ocorrência do pico, redução nos valores de viscosidade e extinção da quebra, ou seja, estabilização da viscosidade dos amidos quando sob temperaturas elevadas e agitação mecânica. O amido de gengibre apresentou modificações menos acentuadas para as propriedades viscoamilográficas, uma vez que, por natureza, já apresentava um perfil similar aos que os outros dois amidos vieram a apresentar após o tratamento.

* O tratamento térmico sob baixa umidade, nas condições do estudo, promoveu alterações na estrutura granular dos amidos estudados. Tais alterações, variáveis com as fontes de amidos estudadas, apontam para rearranjos das zonas cristalinas e/ou amorfas dos grânulos, alterando a proporção das mesmas. No caso do amido de mandioquinha-salsa e de gengibre estas modificações causadas pelo rompimento e reassociações internas da estrutura granular causaram redução da cristalinidade, com aumento significativo de sua área acessível à ação enzimática, principalmente para o primeiro. Já para o amido de batata-doce, de estrutura granular que lhe confere uma elevada suscetibilidade enzimática natural, as modificações impostas pelo tratamento térmico resultaram em aumentos pouco 
expressivos da porcentagem de digestão, entretanto, tais modificações apareceram de modo mais significativo para propriedades de pasta. 


\section{REFERÊNCIAS BIBLIOGRÁFICAS}

ABE, J.; NAKAJIMA, K.; NAGANO, H.; HIZUKURI, S. E OBATA, K. Properties of the raw-starch digesting amylase of Aspergillus SP K-27: a synergistic action of glucoamylase and alpha-amylase. Carbohydrate Research, v.175, p.85-92, 1988.

ASSOCIATION OF OFFICIAL ANALYTICAL CHEMISTRY (AOAC). Official methods of analysis. 12.ed. Washington, 1994. v.1.

BeMILLER, J.N. Starch modification: challenges and prospects. Starch/Stärke, v.49, n.4, p.127-131, 1997.

BERTOLINI, A.C. Avaliação de fécula e farelo de mandioca como substratos para produção de ciclodextrinas. Piracicaba, 1995. 142p. Dissertação (Mestrado) Escola Superior de Agricultura "Luiz de Queiroz", Universidade de São Paulo.

BILIADERIS, C.G. The structure and interactions of starch with food. Canadian Journal of Physiology and Pharmacology, v.69, p.60-78, 1991.

BLANSHARD, J.M.V. Starch granule and function: a physicochemical approach. In: GALLIARD, T. Starch: properties and potencial. 2.ed. Chichester: Wiley, 1987. cap.5, p.16-54.

BLENNOW, A. Starch molecular structure and phosphorylation investigated by a combined chromatographic and chemometric approach. Carbohydrate Polymers, v.41, n.2, p.163-174, 2000. 
BRASIL. Leis, decretos, etc. Decreto n¹2.486 de 20 de outubro de 1978. Diário Oficial do Estado de São Paulo, 21 out. 1987. p.20. Normas técnicas especiais relativas a alimentos e bebidas.

BULÉON, A.; COLONNA, P.; PLANCHOT, V.; BALL, S. Starch granules: structure e biosynthesis. International Journal of Biological Macromolecules, v.23, p.85$112,1998$.

CÂMARA, F.L.A. Mandioquinha salsa: grande potencial com novas técnicas. Agropecuária Catarinense, v.6, n.2, p.25-27, 1993.

CAMARGO FILHO, W.P.; MAZZEI, A.R.; ALVES, H.S. Mercado de raízes e tubérculos: análise de preços. Informações Econômicas, v.31, n.2, p.36-44, 2001.

CEREDA, M.P.; LEONEL, M. Caracterização físico-química de algumas tuberosas amiláceas. Ciência e Tecnologia de Alimentos, v.22, n.1, p.65-69, 2002.

COLLADO, L.S.; CORKE, H. Heat-moisture treatment effectson sweet potato starches differing in amylose content. Food Chemistry, v.65, p.329-346, 1999.

CONE, J.W.; WOLTERS, M.G.E. Some properties and degradability of isolated starch granules. Starch/Starke, v.42, n.8, p.298-301, 1990.

CUI, R.; OATES, C.G. The effect amylase-lipid complex formation on enzyme susceptibility of sago. Food Chemistry, v.65, p.147-425, 1999.

FRANCO, C.M.L.; CIACCO, C.F. Efeito do tratamento térmico com baixa umidade sobre as propriedades físico-químicas de amostras comerciais de amidos de milho e mandioca. Ciência e Tecnologia de Alimentos, v.15, n.2, p.112-117, 1995. 
FRANCO, C.M.L. Estudo da suscetibilidade do grânulo de amido " in natura” ao ataque enzimático. Campinas, 1986. 99p. Dissertação (Mestrado) - Universidade Estadual de Campinas.

FRANCO, C.M.L. Contribuição ao estudo da estrutura do grânulo de amido de milho: tratamento térmico, hidrólise enzimática e permeação em gel. Campinas, 1993. 137p. Tese (Doutorado) - Universidade Estadual de Campinas.

FRANCO, C.M.L.; DAIUTO, É.R.; DEMIETE, I.M.; CARVALHO, L.J.C.B.; LEONEL, M.; VILPOUX, O.F.; SARMENTO, S.B.S. Propriedades gerais do amido. São Paulo: Fundação Cargill, 2001. 221p. (Série Culturas de Tuberosas Amiláceas Latino Americanas, 1)

FRANCO, C.M.L.; CABRAL, R.A.F.; TAVARES, D.Q. Structural and physicochemical characteristics of lintnerized native and sour cassava starches. Starch/Stärke, v.54, p.469-475, 2002.

FRENCH, D. Chemical and physical properties of starch. Journal of Animal Science, v.37, n.4, p.1048-1061, 1973.

FRENCH, D. Organization of starch granules. In: WHISTLER, R.L.; BeMILLER, J.N.; PASCHAL, E.F. Starch: chemistry and technology. 2.ed. London: Academic Press, 1984. cap.7, p.183-247.

FRENCH, D. Chemical and biochemisry of starch. In: WHELAN, W.L. Biochemistry: chemistry of carbohydrates. London: Academic Press, 1975. v.5, p.269-326.

GALLANT, D.; BEWA, Q.H.; BOUCHET, B.; SZULIT, O.; SEALY, L. On ultra structural and nutritional aspects of some tropical tuber starch. Starch/Stärke, v.34, n.8, p.255-262, 1982.

GALLANT, D.J.; BOUCHET, B.; BADWIN, P.M. Microscopy of starch: evidence of a new level of granule organization. Carbohydrate Polymers, v.32, p.177-191, 1997. 
GARCIA, A.C.D.B.; LEONEL, M. Análises microscópicas de grânulos de amido de amidos de mandioca (Manihot esculenta), batata-doce (Ipomoea batatas), biri (Canna edulis) e taioba (Xanthosoma $s p$ ). In: REUNIÃO CIENTÍFICA EM CIÊNCIAS AGRÁRIAS DO LAGEADO, 9., Botucatu, 2002. Anais. Botucatu: Unesp, 2002. p.21-25.

GARCIA, A.M.; WALTER, W.M. Physicochemical characterizaion of starch from Peruvian sweet potato selections. Starch/Stärke, v.50, p.331-337, 1998.

GERNAT, C.; RODOSTA, S.; DAMASCHUN, G.; SCHIERBAUM, F. Supramolecular structure of legume starches revealed by x-ray scattering. Starch/Stärke, v.42, n.5, p.175-178, 1990.

GONZALES, G.; CARRASCO, R.R. Extracción y caracterización del almidón de peruvian carrot (Arracacia Xanthorrhiza Bancroft) y su resistencia a tratamientos tecnológicos. In: SIMPOSIO LATINO AMERICANO DE RAICES Y TUBERCULOS, 2., Lima, 2001. Anais. Lima: FS, 2001. p.0-12.

GUNARATNE, A.; HOOVER, R. Effect of heat-moisture treatment on the structure and physicochemical properties of tuber and root starches. Carbohydrate Polymers, v.49, p.425-437, 2002.

GUZMÁN-MALDONADO, H.; PAREDES-LÓPES, O. Amylolytic enzymes and products derived from starch: A review. Critical Reviews in Food Science and Nutrition, v.36, n.5, p.373-403, 1995.

HOOVER, R.; MANUEL, H. Effect of heat-moisture treatment on the structure and physicochemical properties of legumes starches. Food Research International, v.29, n.8, p.731-750, 1996.

HOOVER, R. Composition, molecular structure, and physicochemical of tuber and root starches: a review. Carbohydrate Polymers, v.45, p.253-267, 2001. 
IMBERTY, A.; BULEON, A.; TRANS, V.; PÉREZ, S. Recent advances in knowledge of starch structure. Starch/Stärke, v.43, n.10, p.375-374, 1991.

INSTITUTO ADOLPH LUTZ. Normas analíticas do Instituto Adolph Lutz: métodos químicos e físicos para análise de alimentos. 3.ed. São Paulo, 1985. v.1.

INTERNATIONAL ORGANIZATION FOR STANDARDIZATION. Norme internationale: Riz-détemination de la teneur en amylose, 1987. ISO 6647.

KASEMSUWAN, T.; JANE, J.; SCHNABLE, P.; STINARD, P.; ROBERTSON, D. Characterization of the dominant mutant amylose-extender (Ael-5180) maize starch. Cereal Chemistry, v.72, n.5, p.457-464, 1995.

KERR, R.W. Chemistry and industry of starch. New York: Academy Press, 1950. $719 p$.

KULP, K.; LORENZ, K. Heat-moisture treatment of starches. I. Physicochemical properties. Cereal Chemistry, v.58, n.1, p.46-48, 1981.

LEACH, H.W.; MCCOEN, L.D.; SCHOCH, T.J. Structure of the starch granule: I. Swelling and solubility patterns of various starches. Cereal Chemistry, v.36, n.6, p.534-544, 1959.

LEACH, H.W.; SCHOCH, T.J. Structure of the starch granule. II. Action of various amylases on starches. Cereal Chemistry, v.38, p.318-327, 1963.

LEACH, H.W. Determination of intrinsic viscosity of starches. Cereal Chemistry, v.40, n.6, p.593-600, 1963.

LIM, S.T.; KASEMSUWAN, T.; JANE, J.L. Characterization of phosphorus in starch by 31p nuclear magnetic spectroscopy. Cereal Chemistry, v.71, p.468-472, 1994. 
LORENZ, K.; KULP, K. Cereal and root starch modification by heat-moisture treatment. Physico-chemical properties. Starch/Stärke, v.34, n.2, p.50-54, 1982.

MAGALHÃES, M.T.; KOKETSU, M.; GONÇALVES, S.L.; DUARTE, F.R.; GODOY, R.L.O.; LOPES, D. Gengibre (Zingiber officinale Roscoe) brasileiro: aspectos gerais, óleo essencial e oleoresina. Parte 1. Aspectos gerais, óleo essencial. Ciência e Tecnologia de Alimentos, v.17, n.1, p.64-69, 1997.

McPHERSON, A.E.; JANE, J. Comparison of waxy potato with other root and tuber starches. Carbohydrate polymers, v.40, p.51-70, 1999.

MILLER, G.L. Use of dinitrossalicylic acid reagent for determination of reducing sugars. Analytical Chemistry, v.31, n.3, p.426-428, 1959.

MORRISON,W.R. Starch lipids and how they relate to starch granule structure and functionality. Cereal Foods World, v.40, p.437-446, 1995.

MUHRBECK, P. Annealing effects on potato starch functionality. In: CONFERÊNCIA INTERNACIONAL DE ALMIDÓN, 1996, Quito. Anais. Quito: Almidón, 1996. p.123128.

NELSON, N.A. Photometric adaptation of the Somogy method for the determination of glucose. Journal of Biological Chemistry, v.153, p.375-380, 1944.

NODA, T.; TAKAHATA, Y.; NAGATA, T. Properties of sweet potato starches from different tissue zones. Starch/Stärke, v.44, n.10, p.365-368, 1992a.

NODA, T.; TAKAHATA, Y.; NAGATA, T. Developing changes in properties of sweet potato starches. Starch/Stärke, v.44, p.405-409, 1992b.

PEREIRA, A.S.; SANTOS, F.F. Processamento industrial de mandioquinha-salsa. Informe Agropecuário, v.19, n.190, p.56-60, 1997. 
PERONI, F.H.G. Características estruturais e físico-químicas de amidos obtidos de diferentes fontes botânicas. São José do Rio Preto, 2003. 107p. Dissertação (Mestrado) - Faculdade de Engenharia de Alimentos, Universidade Estadual Paulista "Júlio de Mesquita Filho".

REYES, F.G.R.; DÁPPOLONIA, B.L.; CIACCO, C.F.; MONTGOMERY, M.W. Characterization of starch from ginger root (Zingiber officinale). Starch/Stäke, v.34, n.2, p.40-44, 1982.

ROBIN, J.P.; MERCIER, C.; CHARBONNIERE, R.; GUILBOT, A. Lintnerized starches gel filtration and enzymatic studies of insoluble residues from prolonged acid treatment of potato starch. Cereal Chemistry, v.51, n.3, p.389-406, 1974.

ROSENTHAL, F.R.T.; MELlO, A.P.; PELEGRINO, S.L.; NAKAMURA,T. Amidos de mandioca. 2. Estudos de estrutura, em variedades de Minas Gerais. Revista Brasileira de Tecnologia, v.4, p.7-17, 1973.

SANDSTEDT, R.M.; KNEEN, E.; BLISH, M.J. A standardized wohlgemuth procedure for alpha-amylase activity. Cereal Chemistry, v.16, n.6, p.712-723, 1939.

SANDSTEDT, R.M.; STRAHAN, D.; UEDA, S.; ABBOT, R.C. The digestibility of highamylose corn starches compares to that of other starches the apparent effect of the ae gene on susceptibility to amylase action. Cereal Chemistry, v.39, n.2, p.123$131,1962$.

SARMENTO, S.B.S. Caracterização da fécula de mandioca (Manihot esculenta C.) no período de colheita de cultivares de uso industrial. São Paulo, 1997. 162p. Tese (Doutorado) - Faculdade de Ciências Farmacêuticas, Universidade de São Paulo.

SARRUGE, J.R.; HAAG, H.P. Análises químicas em plantas. Piracicaba: USP/ESALQ, 1974. 56p. 
SCHOCH, T.J.; MAYWALD, E.C. Microscopic examination of modified starches. Analytical Chemistry, v.28, n.3, p.382-387, 1956.

SOMOGY, M. Determination of blood sugar. Journal of Biological Chemistry, v.160, p.69-73, 1945.

SRIRITH, K.; PIYACHOMWAN, K.; SANGSEETHONG, K.; OATES, C. Modification of cassava starch. In: INTERNATIONAL STARCH CONVENTION, Cracow, 2002. Anais. Varsóvia: Poland, 2002. p.1-14.

STUTE, H. Hydrothermal modification of starches: the difference between anneling and heat-moisture treatment. Starch/Stärke, v.44, n.6, p.205-214, 1992.

TAKEDA, Y.; TAKUNAGA, N. TAKEDA, C.; HIZUHURI, S. Physicochemical properties of sweet potato starches. Starch/Stärke, v.38, p.345, 1986.

TESTER, R.F.; DEBBON, S.J.J. Annealing of starch: a review. International Journal of Biological Macromolecules, v.27, p.1-12, 2000.

TESTER, R.F.; KARKALAS, J.; QI, X. Starch: composition, fine structure and architecture. Journal of Cereal Science, n.39, p.151-165, 2004.

THOMAS, D.J.; ATWELL, W. Practical for guides the food industry-starch. St. Paul: Eagan Press, 1999. 94p.

TIAN, S.J. RICKARD, J.E.; BLANSHARD, J.M.V. Physicochemical properties of sweet potato starch. Journal of Science and Food Agriculture, v.57, p.459-491, 1991.

UEDA, S.; OHBA, R.; KANO, S. Fractionation of the glucoamylase system from blachkoji mold and the effects of adding isoamylase and alpha-amylase on amylolysis by the glucoamylase. Starch/Stärke, v.26, n.11, p.374-378, 1974. 
UEDA, S.; ZENIN, C.T.; MONTEIRO, D.A.; PARK, Y.K. Production of ethanol from raw cassava starch by a non-conventional fermentation method. Biotechnology and Bioengineering, v.23, n.2, p.291-299, 1980.

VAN DER BURGT, Y.E.M.; BERGSMA, J.; BLEEKER, I.P.; MIJLAND, P.J.H.C.; KAMERLING, J.P.; VLIEGENHART, J.F.G. Structural studies on methylated starch granules. Starch/Stärke, v.52, n.2-3, p.40-43, 2000.

VAN BEYNUM, G.M.A.; ROELS, J.A. Starch conversion technology. New York: Marcel Dekker, 1985. 362p.

WANG, Y.J.; WHITE, P. Structure and properties of amylose, amylopectin and intermediate materials of oat starches. Cereal Chemistry, v.71, p.263-268, 1994.

WU, H.H.; SARKO, A. The double-helical molecular structure of crystalline A-amylose. Carbohydrate Research, v.61, p.7-25, 1978a.

WU, H.H.; SARKO, A. The double-helical molecular structure of crystalline B-amylose. Carbohydrate Research, v.61, p.27-40, 1978 b.

ZHANG, T.; OATES, C.G. Relationship between $\alpha$-amylase degradation and physicochemical properties of sweet potato starches. Food Chemistry, v.65, p.157-163, 1999.

ZOBEL, H.F. X-ray analysis of starch granules. In: WHISTLER, R.L. Methods in carbohydrates chemistry. London: Academic Press, 1964. v.4, p.109-143.

ZOBEL, H.F. Starch crystal transformations and their industrial importance. Starch/Stärke, v.10, n.1, p.1-7, 1988a.

ZOBEL, H.F. Molecules to granules: a comprehensive starch review. Starch/Stärke, v.40, n.2, p.44-50, 1988b. 
ZOBEL, H.F.; YOUNG, S.N.; ROCCA, L.A. Starch gelatinization: an X-ray diffraction study. Cereal Chemistry, v.65, n.6, p.443-446, 1988c. 